\title{
KARO ISTORIJA IR JOS SVARBA LIETUVOS KARIUOMENEI TARPUKARIU
}

\author{
Dr. Vytautas Jokubauskas \\ Klaipédos universiteto \\ Baltijos regiono istorijos ir archeologijos institutas
}

Žvelgiant globaliai, karo istorijos tyrimai, kaip ir karybos teorijų bei karo mokslų plètra apskritai, turi senas tradicijas. Karybos tematika paliečiama Senajame Testamente ${ }^{1}$, senovès Egipte faraono Ramzio II valdymo laikotarpiu imtasi mūšių (pvz., Kadešo mūšio) „aprašymų“. Herodotas savo veikale nemažai dèmesio skiria karų ir mūšių aprašymui², panašiu laiku karybos tema rašè kinų autorius Sun $\mathrm{Tzu}^{3}$ ir indų politikos veikèjas, brahmanas Chanakya (dar žinomas Kauțilya ir Vishnugupto vardais) ${ }^{4}$. Galima įvardyti ir kitus praeities autorius, kurie aprašè karus, kai kurie iš jų - kaip tiesioginiai jų dalyviai, kiti - surinkę atitinkamą medžiagą ${ }^{5}$.

\footnotetext{
1 Pvz., vienas žinomiausių epizodų apie žydų tautos išèjimą iš Egipto aprašomas kariniame kontekste - faraono kariuomenè juos vijosi, o „izraeliečiai iš Egipto leidosi kelionèn mūšio gretomis“. Išejimo knyga. 13:18. Šventasis Raštas. Senasis ir Naujasis testamentai. Vilnius, 2009, p. 146.

${ }^{2}$ Herodotas. Istorija. Vilnius, 2008.

3 Sun Tzu. Karo menas. Kaunas, 2007.

4 Nors autorystès klausimas diskutuotinas: Артхашастра или наука политики. Москва, 1959.

5 Teiktini keli pavyzdžiai: Ksenofontas. Anabasis. Marijampolè, 1931; Thucydides. History of the Peloponnesian war. London, 1972; Фукидид. История. Москва, 1999; Гай Саллюстий Крисп. Записки Юлия Цезаря и его продолжателей о Галльской войне, о гражданской войне, об Александрийской войне, об Африканской войне. Москва, 1999; Gaius Iulius Carsar. Galu karo užrašai. Vilnius, 1998; Gajus Salustijus Kripsas. Katilinos sqmokslas. Jugurtos karas. Vilnius, 1973; Titas Livijus. Hanibalo karas: Romos istorijos XXIXXIII knyga. Vilnius, 1976; Секст Юлий Фронтин. Стратегемы. Военные хитрости. Москва, 2003; Publijus Kornelijus Tacitas. Rinktiniai raštai. Vilnius, 1972; Plutarchas. Rinktinés biografijos. Vilnius, 1962; Стратегикона Маврикия. Санкт-Петербург, 2004.
} 
Karo istorikas Valdas Rakutis karybos istorijos (tai siauresnè sąvoka nei karo istorija) vadovèlyje, skirtame karininkams, išskyrė Herodotą, Tukididą, Cezarị, Ksenofontą, Sekstą Julijų Frontinį, Enèją, Onisandrą ir Publijų Flavijų Vegecijų Renatą - antikos laikotarpio veikejjus, taip pat du XVI a. autorius - Niccolą Machiavellị ir Justą Lipsijų, kaip karybos istorikus ir teoretikus ${ }^{6}$. Tačiau galime paminèti ir XIV-XV a. sandūroje kūrusią Christiną de Pizan, kuri vieną iš savo knygų skyrẻ riterių klausimams $^{7}$ (Livre des faits d'armes et de la chevalerie, $1405 \mathrm{~m}$.), taip pat karo inžinieriaus Conrado Kyeserio Eichstätto veikalą Bellifortis (1405 m.) ir jo amžininko Giovannio Fontanos darbą Bellicorum instrumentorum liber $(1420 \text { m. })^{8}$. Viduramžiais karyba Vakarų Europoje pakito, buvo pereita prie sunkiosios kavalerijos - riterių kariuomenių, o antikinè karybos patirtis primiršta. Tačiau kartu su Renesanso epocha „atgimë“ ir „grịžo“ i mūšių laukus muštruotų ir griežta rikiuote veikiančių pẻstininkų kariuomenès. Remdamasis antikos karybos analize ir Justo Lipsijaus knyga $^{9}$, Mauritsas van Oranje (van Nassau) Nyderlandų kariuomenejje idiegè naują rikiuotès ir kautynių metodą, kuris aprašytas $1608 \mathrm{~m}$. išleistoje Jacobo de Gheyno knygoje ${ }^{10}$. Naująją sistemą perèmè ir puikiai pritaikè Gustavo II Adolfo Švedijos kariuomenè ${ }^{11}$, taigi susidomèjimas antikos karo istorija sudarè prielaidas esminiams karybos pokyčiams, igyventintiems ir remiantis pamokoma patirtimi.

Šiame kontekste ịvardytini ir kiti karybos temomis rašę autoriai: Le-

Galima išvardyti nemažai antikinès Graikijos, Romos ir Bizantijos autorių veikalų apie karybą ir karo meną: Военная мысль Античности. Сочинения древнегреческих и византийских авторов. Сост. К. Королева. Москва, Санкт-Петербург, 2002; Makiavelis, N. Rinktiniai raštai. Vilnius, 1992; Machiavelli, N. Art of war. Chicago, London, 2003; De Constantia Libri Duo. Mit einem Einl. Hrsg. Von W. Weber. Hildesheim, 2002.

${ }^{6}$ Rakutis, V. Karo meno istorija, I dalis. Nuo seniausių laiku iki 1850 metu. Vilnius, 2012, p. 8-9.

7 Кревельд, ван М. Трансбормация войны. Москва, 2008, с. 149.

8 Ивашкявичюс, А. Казимир Семенович и его книга „Великое искусство артиллерии“: часть первая. Вильнюс, 1971, с. 3.

9 Lipsius, J. De militia Romana libri quinque, commentarius ad Polybium. Antverpenas, 1595.

${ }^{10}$ Gheyn, de J. Wapenhandelingen van Roers, Musquetten ende Spiesen. Amsterdam, 1608.

${ }^{11}$ Rakutis, V. Karo meno istorija, I dalis. Nuo seniausiu laiku iki 1850 metu. Vilnius, 2012, p. 126. 
onhardas Fronspergeris ${ }^{12}$, Giorgio Basta ${ }^{13}$, Matas Pretorijus ${ }^{14}$, Johannas Jacobi von Wallhausenas ${ }^{15}$, Joachimas Meÿeris ${ }^{16}$, Kazimieras Simonavičius $^{17}$ ir jo amžininkas Nathanielis $\mathrm{Nye}^{18}$. Paminètinas XVII a. karo vadas ir teoretikas Raimondo Montecuccoli ${ }^{19}$, fortifikacijos raidoje išskirtinị vaidmenị suvaidino karo inžinierius ir Prancūzijos maršalas Sébastienas Le Prestre de Vaubanas, kuris paliko ne vieną karybos veikalą, XVIII a. Prancūzijos maršalas, vienas iš daugybès Abiejų Tautų Respublikos karaliaus Augusto II nesantuokinių sūnų Hermannas Moritzas von Sachsenas, kuris 1732 m. per 13 dienų sirgdamas parašè veikalą apie karo meną ${ }^{20}$. Jeanas Charlesas de Folardas analizavo graikų ir romėnų taktiką $^{21}$ ir tuo remdamasis siūlè keisti kariuomenès rikiuotę mūšio metu. Humphrey’o Blando veikalas ${ }^{22}$ tapo tam tikra D. Britanijos armijos „Biblija“. Henry Humphrey Evansas Lloydas savo veikaluose analizavo karo

${ }^{12}$ XVI a. išleistų karybos veikalų Besatzung (1563), Von Kayserlichen Kriegßrechten (1564), Geistliche Kriegß-Ordnung (1565), Das Kreigsbuch (1573) autorius.

${ }^{13}$ Veikalų Il maestro di campo generole (1606) ir Governo della cavalleria leggiera (1612) autorius.

${ }^{14}$ Pretorii, M. Mars Gothicus, id est traktatus historicus. Oliva, 1691.

${ }^{15}$ Plačiau žr.: Arte et Marte. Senieji dokumentai karo tema, skirti Žalgirio mūšio 600-osios metinèms. Parodos katalogas. 2010 m. liepos 7-rugpjūčio 3 d. [2016 10 01] < http://www.mab.lt/Zalgirio/01.html >; Lukšaitè, I. Vilniaus vaivados Jonušo Radvilos asmeninès bibliotekos Kèdainiuose sąrašas - asmens kultūrinių orientacijų žymuo. Lietuvos istorijos metraštis. 2005 metai, 2. 2006, p. 41.

${ }^{16}$ Meyer, J. Gründtliche Beschreibung der freyen Ritterlichen unnd weltlichen Kunst des Fechtens in allerley gebreuchlichen Weren. Strassburg, 1570.

${ }^{17}$ Siemienowicz, C. Artis Magnae Artilleriae Pars prima. Amsterdamas, 1650. Plačiau apie autorių, jo veikalą ir vieno skyriaus vertimą ị rusų kalbą žr.: Ивашкявичюс, A. Казимир Семенович и его книга „Великое искусство артиллерии“: часть первая. Вильнюс, 1971; Бельскі, А. М.; Ткачоў, М. А. Вялікае мастацтва артылерыі: Казімір Семяновіч. Мінск, 1992.

${ }^{18}$ Nye, N. The Art of Gunnery. London, 1647.

${ }^{19}$ Монтекукколи, Р. Записки Монтекукколи, генералиссимуса императорских войск, или Общие принципы военного искусства в трех книгах. Монреаль, 2012.

${ }^{20}$ Мориц Саксонский. Теория военного искусства. Москва, 2009.

${ }^{21}$ Folard de J.-C. Histoire de Polybe. Nouvellement Traduite du Grec Par Dom Vincent Thuillier, Avec un Commentaire ou un Corps de Science Militaire. Amsterdam, 1753.

${ }^{22}$ Bland, H. A Treatise of Military Discipline: In Which is laid down and Explained the Duties of Officer and Soldier. London, 1727. 
istoriją ir eventualią priešo ịsiveržimo ỉ D. Britaniją grèsmę $e^{23}$. Prūsijos karalius Frydrichas II Didysis, laikomas vienu žymiausių karo vadų, taip pat įnešè savo indèli i karo mokslus - savo generolams parašė Nurodymus (vok. Die Instruktion Friedrichs des Grossen für seine Generäle) ${ }^{24}$.Tai tik keletas pavyzdžių, rodančių, kad karo (karybos) istorijai buvo skiriama pakankamai dèmesio, nors minètus veikalus ir kitus senovès, antikos ir naujųjų laikų autorių darbus, vertindami iš XXI a. perspektyvos, greičiau priskirtume šaltiniams arba karybos praktiniams vadovams, karo meno veikalams, specializuotiems karo inžinerijos ar artilerijos darbams, o ne analitiniams karo istorijos ar karybos tyrimams. Dalies ịvardintų autorių darbuose „platesnių apibendrinimų pasitaiko retai“ “25, tačiau karo istorija ir karybos teorija - neatsiejamos karo mokslų dalys. Tikras proveržis karo istorijos tyrimuose įvyko XIX a. po Napoleono karų. Jie suteikè daug medžiagos nuodugnesnei analizei ir apmąstymams. Vieni žinomiausių ir bene didžiausią ịtaką karybai padariusių - imperatoriaus Napoleono Bonaparto amžininkai, jo epochos karų dalyviai, Antoine'as Henris Jomini $^{26}$ (jo biografija susijusi ir su Lietuva - $1812 \mathrm{~m}$. Napoleono Grande Armée žygio ị Rusiją metu buvo paskirtas Vilniaus miesto gubernatoriu$\mathrm{mi}^{27}$ ), Carlas Philippas Gottliebas von Clausewitzas ${ }^{28}$, Adamas Heinrichas Dietrichas Freiherris von Bülowas, kuris suformulavo šiuolaikinę strategijos termino (jị pirmasis 1771 m. pavartojo Prancūzijos karininkas Paulas Gédéonas Joly de Maïzeroy ${ }^{29}$ ) definiciją ir pagrindè strategijos at-

${ }^{23}$ Lloyd, H. H. E. The History of The Late War in Germany between The King of Prussia and The Empress of Germany. Landon, 1766; Lloyd, H. H. E. A Political and Military Rhapsody on the Invasion and Defence of Great Britain. London, 1790.

${ }^{24}$ Фридрих Великий. Наставление о военном искусстве к своим генералам. АнтиМакиавелли. Москва, 2014.

${ }^{25}$ Rakutis, V. Karo meno istorija, I dalis. Nuo seniausiu laiku iki 1850 metu. Vilnius, 2012, p. 8 .

${ }^{26}$ Jomini, A. H. Précis de l'Art de la Guerre: Des Principales Combinaisons de la Stratégie, de la Grande Tactique et de la Politique Militaire. Brussels, 1838; Жомини, Г. Стратегия и тактика в военном искусстве. Москва, 2009.

${ }^{27}$ Pugačiauskas, V. Napoleonas ir Vilnius: karinio gyvenimo kasdienybès bruožai. Vilnius, 2004, p. 29.

${ }^{28}$ Clausewitz, von C. Apie kara. I dalis. Vilnius, 2008; Clausewitz, von C. Apie kara. II dalis. Vilnius, 2009.

${ }^{29}$ Кревельд ван М. Трансформация войны. Москва, 2008, с.150-151. 
skyrimą nuo taktikos ${ }^{30}$. Visi jie savo veikaluose plačiai remiasi karo istorijos pavyzdžiais.

Vienas iš pirmụjų šiuolaikinių karo istorikų Hansas Gottliebas Leopoldas Delbrückas, kuriuo Vokietijos kariuomenès generalinio štabo oficialūs istorikai nebuvo patenkinti dèl tam tikrų ǰžvalgų ir kritiško Prūsijos karaliaus Frydricho II Didžiojo vertinimo ${ }^{31}$, savo keturtomio apie karo meno istoriją politikos istorijos kontekste $1900 \mathrm{~m}$. išleistoje pirmoje dalyje pažymėjo, kad karo istorijos, ypač karo meno, tyrëjai susiduria su problema, kai civiliai turi ilgai studijuoti karo meną ir apskritai karybą. Gerai, jei jiems bent trumpai teko tarnauti kariuomeneje ir susipažinti su jos veikla. Profesionalūs karininkai, nusprendę imtis karo istorijos tyrimų, susiduria su humanitarinio išsilavinimo stokos problema. Ivade prisipažinęs rašantis Leopoldo von Rankeso dvasia, autorius pažymèjo, kad tik patyręs istorikas, remdamasis kritikos metodu, gali pateikti išsamų praeities vaizdą, o bet kokį karo istorijos tyrimą geriausia pradèti nuo karinių pajègų îvertinimo, nes jų dydis ne tik turi ịtakos karo eigai ir baigčiai, bet ir aprūpinimui, logistikai. Savo tyrime (karo meno) jis pabrèžè socialinès ekonomikos ir politinès istorijos svarbą ${ }^{32}$. Gana plačiai karo istorijos pavyzdžiais savo darbuose istorijos tematika remiasi ir Johannas Gustavas Bernhardas Droysenas ${ }^{33}$.

Karo istorija - mokslinių tyrimų šaka ${ }^{34}$, aktuali siekiant įvertinti visuomenès raidą, o karas ir kariuomenè vaidina išskirtini vaidmeni ir

\footnotetext{
${ }^{30}$ Bülow, A. Geist des neuern Kriegssystems, hergeleitet aus dem Grundsatze einer Basis der Operationen. Hamburg, 1805; Германская военная мысль. Сос. К. А. Залесский. Москва, 2012, с. 29-69; Бюлов А. Г. Д. Дух новейшей военной системы. Стратегия в трудах военных классиков. Москва, 1926. [2016 10 26] < http://militera.lib.ru/science/ bulow/index.html >.

31 Залесский, К. А. Ганс Дельбрюк. Германская военная мысль. Москва, 2012, c. 426-428.

${ }^{32}$ Delbrück, H. Geschichte der Kriegskunst im Rahmen der politischen Geschichte. Bd. 1: Das Altertum. Berlin, 1900, S. v-xii, 1-2, 7.

33 Дройзен, И. Г. Историка. Санкт-Петербург, 2004.

${ }^{34}$ Remiantis Lietuvos Respublikos teisès aktais, karo istorija (V390) yra humanitarinių mokslų srities, istorijos krypties grupès šaka: Lietuvos Respublikos švietimo ir mokslo ministro $2010 \mathrm{~m}$. vasario 19 d. ịsakymu Nr. V-222 patvirtintas Studijų kryptis sudarančiu šaku squrašas.
} 
modernių valstybių istorijoje ${ }^{35}$. Nuo XX a. 7-ojo dešimtmečio JAV akademiniuose karo istorijos tyrejų sluoksniuose susidomèta nauja tyrimų kryptimi, kuri ịvardijama kaip „karas ir visuomene“. Pradèta kelti klausimus, kas sudare karines pajègas, kodèl „jie“ kovojo ir kas „jiems“ atsitiko. Atsakymai ị klausimus apie pajègų organizaciją ir karių patirtis padejo rasti atsakymus ir $\mathfrak{i}$ daug svarbesnius klausimus apie karių vertybes, lūkesčius, motyvaciją. Galiausiai buvo mestas iššūkis paradigmai, kad karas yra racionalus, apskaičiuotas valstybių politikos tęsimas kitomis, t. y. karinėmis, priemonėmis. Šią paradigmą XIX a. ịtvirtino Prūsijos karybos teoretikas C. von Clausewitzas ${ }^{36}$. JAV karo istorikas Victoras Davisas Hansonas, išanalizavęs senovès graikų patirtị, konstatavo, kad jie sukūrè savitą karybos kultūrą, o ją vèliau perèmė Vakarų kultūros. Šiuos tyrimus išplètojo karo istorikas seras Johnas D. P. Keeganas, kuris įrodè, kad karas apima daugiau nei politiką. Karas beveik toks pat senas kaip žmogus ir pasiekia slapčiausias jo širdies vietas, kuriose, nepaisant proto, nelieka racionalumo. Taigi ị karą žvelgiama kaip ị kultūrų išraišką, tžzelgiant vakarietiškos ir rytietiškos kariavimo kultūrų skirtị. Todèl atsiranda galimybè atlikti kultūrų tyrimus, kurie atskleistų kultūrines prielaidas kurti ir panaudoti karines pajègas ${ }^{37}$. Tačiau JAV Kanzaso universiteto istorijos profesorius Davidas R. Stone' as konstatavo, kad karo istorija niekada neišgy-

\footnotetext{
${ }^{35}$ Chambers, II J. W. The New Military History: Myth and Reality. Journal of Military History, No 55 (July 1991), pp. 398-406.

${ }^{36}$ Apskritai C. von Clausewitzui XX a. karybos teoretikas Basilis Henris Liddellis Hartas pažèrè nemažai kritikos, kad jo idejjų adeptai, visapusiškai adoruodami C. von Clausewitzą, nevisiškai suprato filosofiškai parašytą tekstą, kuris nebuvo galutinis autoriaus darbas, o tik po mirties jo žmonos išleistas variantas. Teigiama, kad jis nieko naujo neįnešè ị karybą taktikos prasme, tik atkreipé dėmesị ị karių motyvacijos ir psichologijos problemas. Jo idejos apie karo totalumą paskatino masinių armijų XIX a. pabaigoje - XX a. pradžioje kūrimą, nors dèl industrializacijos ir technologinių inovacijų kaip tik kariuomenès turejjo mažèti, nes jų naudojamų priemonių ugnies galia ir greitašauda buvo didesnè, o mūšio, kaip pagrindinio karo elemento, pabrěžimas lèmè, kad Pirmojo pasaulinio karo metu buvo pereita prie tiesioginių veiksmų strategijos, organizuojant frontaliąsias atakas ir alinamąji karą: Лиддел Гарт, Б. Стратегия непрямых действий. Москва, 2012, c. $478-485$.

${ }^{37}$ Lee, W. E. Mind and Matter - Cultural Analysis in American Military History: A Look at the State of the Field. The Journal of American History, March 2007, vol. 93, no. 4, pp. 1116-1119.
} 
veno „aukso amžiaus“ ir nebuvo populiari akademiniuose sluoksniuose ${ }^{38}$. Net XVIII a. pastebèta, kad knygos apie karą neturi didelio pasisekimo, nes karo rutina „sausa ir nuobodi““39.

Karo istorikas Jeremis Blackas, aptardamas karo istorijos tyrimų perspektyvas XXI a., teigia, kad karo istorikai turi polinkị ị saviizoliaciją, nes pernelyg susitelkia ị karinių operacijų apskritai ir veiksmų fronte konkrečiai analizę ${ }^{40}$. Karo istorijos teoriniai ir empiriniai tyrimai anksčiau buvo laikomi karo reiškinio supratimo pagrindu, tačiau karo istorikų konservatyvumas lèmé, kad karas tapo ir kitų disciplinų tyrimo objektu ${ }^{41}$. Todèl kartais laikomasi nuomonès, kad karo istorija - tai užsièmimas, kuriam nereikia ypatingų intelektinių gebejimų, tačiau Vakarų istoriografijoje karo istorija apima socialinę, kultūros ir politikos istoriją. Europoje ir JAV analizuojamos mažosios kariuomenès, nereguliariosios pajègos, nevalstybiniai karinę jègą naudojantys subjektai, pilietiniai karai ir t. t. ${ }^{42}$

Pabrežiama, kad politikai ir karybos strategai turètų mąstyti istoriškai. Analizuojant analogijas, atskiriant atsitiktinius sutapimus nuo tendencijų, galima kur kas operatyviau priimti spendimus greitai kintančiame pasaulyje. Todèl pagrịsti samprotavimai, kad ir civiliai, ir karybos strategai turètų turèti humanitarinị išsilavinimą (išmanyti istoriją) ${ }^{43}$. Istorijos studijos lavina analitini (horizontaluji) mąstymą ${ }^{44}$, o nuodugnios karo istorijos studijos karininkams atveria daug platesnes analitines galimybes karybos srityje. Todell kariuomenems tenka remtis istorine patirtimi, kurią gali pateikti tik istorijos tyrëjai. Tradiciškai pripažistama, kad karo istorijos akademiniai tyrimai padeda "dabarties“ vadams sèkmin-

\footnotetext{
${ }^{38}$ Stone, D. R. The Future of Military History: A Glass Half Full. Historically Speaking, April 2010, p. 33.

${ }^{39}$ Мориц Саксонский. Теория военного искусства. Москва, 2009, с. 26.

${ }^{40}$ Black, J. Rethinking Military History. London, New York, 2004, p. xi.

${ }^{41}$ Spiller, R. Military History and Its Fictions. The Journal of Military History, vol. 70, Nr. 4 (2006, October), p. 1081.

${ }^{42}$ Moyar, M. The Current State of Military History. The Historical Journal, 2007, 50 (1), pp. 225-240.

${ }^{43}$ Porch, D. Writing History in the "End of History" Era-Reflections on Historians and the GWOT. The Journal of Military History, vol. 70, Nr. 4 (October 2006), pp. 1065-1079. 44 Тош, Д. Стремление к истине. Как овладеть мастерством историка. Москва, 2000, c. 41-42.
} 
giau planuoti ateities operacijas, tai daroma JAV karinèse pajėgose ${ }^{45}$. Be to, pagrịstai teigiama, kad be žinių apie savo praeitị bet kokiai institucijai sunku sėkmingai veikti ${ }^{46}$. Tai rodo ir Lietuvos kariuomenès dalinių puoselèjamos LDK ar tarpukario karinès tradicijos ${ }^{47}$. Taigi teiginys, kad karo istorija yra labai svarbi kariams, laikytina savotiška aksioma. Tačiau tai nereiškia, kad „praeitis pasikartos“ arba kad ją galima tiksliai „nuspèti“, kad galima panaši ịvykių eiga, susiklosčius panašioms aplinkybèms ar tik žinant, kaip buvo pasielgta anksčiau ir kokie buvo viso to rezultatai ${ }^{48}$. Bet atlikus išsamią mokslinę analizę ir atskleidus istorini procesą, remiantis tendencijomis, vis delto galima bandyti numatyti ịvykių eigą. Istorijos tyrimai atskleidžia galimų alternatyvų perspektyvą ir leidžia pasinaudoti patirtimi, kurios negalime pasisemti iš savo asmeninio gyvenimo ${ }^{49}$. Filosofo ir istoriko Robino George'o Collingwoodo teigimu, vystantis Europos civilizacijai, žmonès mąstè istoriškai ir to nenustojo daryti ${ }^{50}$, taigi darytina prielaida, kad kariai taip pat mąsto arba bent jau turètų mąstyti istoriškai. Bet Lietuvoje, nesant padèties tyrimų ir krašto apsaugos sistemos vadovybès aiškios pozicijos, klausimas, kiek karo istorijos tyrimai turi būti fundamentiniai ir kiek - taikomieji, lieka atviras.

\footnotetext{
${ }^{45}$ Lee, W. E. Mind and Matter - Cultural Analysis in American Military History: A Look at the State of the Field. The Journal of American History, March 2007, vol. 93, no. 4, p. 1116.

${ }^{46}$ Coffman, E. M. The Curse of Military History in the United States Since World War II. Journal of Military History, October 1997, no 61, p. 775.

${ }^{47}$ Plačiau žr.: Jokubauskas, V. Trijų autorių per trejus metus parašytos trys naujos triju Lietuvos kariuomenès dalinių istorijos [Rec. kn.: Surgailis, G. Pirmasis pėstininkų Didžiojo Lietuvos kunigaikščio Gedimino pulkas. Vilnius, 2011; Rakutis, V.; Vaičenonis, J. Lietuvos didžiojo kunigaikščio Algirdo mechanizuotojo pėstininkų bataliono istorija: Lietuvos pėstija XIV-XXI a. pr. (II pulko ir Algirdo MPB istorija). Vilnius, 2012; Surgailis, G. Trečiasis péstininkų Didžiojo Lietuvos kunigaikščio Vytauto pulkas. Vilnius, 2013] // Paramilitarism in the Eastern Baltics, 1918-1940: Cases Studies and Comparisons $=$ Paramilitarizmas Rytu Baltijos regione 1918-1940: atvejo studijos ir lyginimai (Acta Historica Universitatis Klaipedensis, vol. XXVIII). Ed. by V. Jokubauskas, V. Safronovas, V. Vareikis. Klaipeda, 2014, p. 269-280.

${ }^{48}$ Carr, E. H. Kas yra istorija? Vilnius, 1999, p. 68-71.

49 Тош, Д. Стремление к истине. Как овладеть мастерством историка. Москва, 2000, с. 36-38.

${ }^{50}$ Коллингвуд, Р. Дж. Идея истории. Автобиография. Москва, 1980, с. 8.
} 
Regis, akivaizdu, kad kariaujama ${ }^{51}$ dèl išteklių. Kitaip tariant, kovoti motyvuoja interesas juos (už)valdyti, tačiau tai suvokti tik kaip kovą dèl materialinių vertybių būtų klaida. Ištekliai - tai sunkiai prieinama priemonè kuriam nors veiksmui atlikti, procesui pradèti. Taigi ištekliai - tai ir vertybiu sistemos, arba simbolinis kapitalas, kuris yra ir simbolinès galios pagrindas ${ }^{52}$, kuri pasitelkus pavyksta generuoti tam tikrus procesus visuomenèje. Kai individų ar jų grupių ịsivaizduojami lūkesčiai būna didesni nei to meto realios galimybès, didelè tikimybė, kad kils ginkluotas susidūrimas kelyje ị tų lūkesčių realizavimą su tais, kurie „trukdo“ pasiekti siekiamybę. Karo istorija apima platų tyrimų lauką, galima išskirti: karų ir karybos istoriją, pagalbinius karo istorijos mokslus, pagaliau sudedamąsias karybos istorijos dalis - kariuomenès, karo meno ir karo minties istoriją ir t. t. ${ }^{53}$ Todèl kai kurių tyrimų (ne)priskyrimas prie karo istorijos yra sąlyginis, tačiau esminiu laikytinas tyrimo objekto kriterijus, o ne koks chronologinis sutapimas ar kontekstas. Nes net ir intensyviausiame kare galima išskirti tyrimo objektus, kurie mažai ką arba iš viso nieko bendro su juo neturi ir neturejjo. Kartu galimas konkretaus karo

\footnotetext{
${ }^{51}$ Apskritai karo priežasčių ir karo fenomeno samprata yra kintanti - XVII a. teoretikas R. Montecuccoli sakè, kad karas - tai kariuomenių, veikiančių viena prieš kitą, veiksmai bet kokiomis priemonèmis ir metodais, siekiant pergalès: Монтекукколи, Р. Записки Монтекукколи, генералиссимуса императорских войск, или Общие приниипы военного искусства в трех книгах. Монреаль, 2012, с. 10; XVIII a. Moritzas von Sachsenas rašè, kad karas - tai menas, persmelktas neaiškumų, neleidžiančių užtikrintai veikti, kurio esmė slypi rutinoje ir prietaruose: Мориц Саксонский. Теория военного искусства. Москва, 2009, с. 26; XIX а. C. von Clausewitzas pateiké nemažai karo apibrěžčių: kad tai - ir politikos tęsinys kitomis priemonemis, ir „prievartos aktas, turintis tikslą priversti priešininką vykdyti mūsų valią“: Clausewitz, von. C. Apie karą. I dalis. Vilnius, 2008, p. 7; Karo priežasčių analizę žr.: Кревельд, ван М. Трансформация войны. Москва, 2008.

${ }^{52}$ Pierre'as Bourdieu išskiria kelias kapitalo rūšis - ekonominị, kultūrinị, socialinị ir „simbolinị“: Bourdieu, P. Social Space and Symbolic Power. Sociological Theory, Vol. 7, No. 1, (Spring, 1989), pp. 14-25.

${ }^{53}$ Klausimą plačiai yra aptaręs karo istorikas V. Rakutis: Rakutis, V. Lietuvos karybos istorija: tarp tradicijos ir naujovių. Darbai ir dienos, 2000, t. XXI, p. 10-16; Rakutis, V. Karo meno istorijos tyrimu metodika. Vilnius, 2006, p. 8-9; Rakutis, V. Karo meno istorija, I dalis. Nuo seniausių laikų iki 1850 metų. Vilnius, 2012, p. 7-8; Šlekys, D. Karyba, karo menas. Karo mokslas. Visuotine lietuviu enciklopedija, t. IX, Vilnius, 2006, p. 423-424, 475-476.
} 
tyrimas jau jam pasibaigus, siekiant nustatyti, kaip veikia demobilizuotos kariuomenès, koks buvo to karo poveikis karybai ir kariams ir t. t. Kaip taikliai pažymèta, karas - tai žygis ir laukimas, nes tik kartais kariai patenka ị tiesioginių karo veiksmų epicentrą. Iki XX a. daugiau karių žūdavo ne mūšio lauke, o stovyklose ir žygio metu nuo įvairių ligų ir nelaimingų atsitikimų. O Vakarų istoriografijoje pastebima ir tam tikra karo istorijos demilitarizacija, kai dèmesys sutelkiamas ne ị kovos veiksmus ir jų planavimą, o į žmones ir jų išgyvenimus ${ }^{54}$.

Lietuvos karo istorijos istoriografijos raidą nuo archeologinių tyrimų iki pokario partizanų kovų yra apžvelgę Valdas Rakutis, Vytautas Lesčius, Jonas Vaičenonis, Mindaugas Pocius ir Manvydas Vitkūnas ${ }^{55}$, o istorikas Valdas Selenis tyrè Lietuvos istorikų bendruomenę ir jos veiklą tarpukariu $^{56}$. Aivas Ragauskas ${ }^{57}$ ir Povilas Lasinskas ${ }^{58}$ analizavo istorijos mokslo tarpukariu problemas. Dešimtmeti (1923-1933 m.) veikusios Karo mokslų draugijos (KMD) ir jos Istorijos sekcijos veiklą nagrinejjo Romas Juzefovičius $^{59}$. Istorikas Aurelijus Gieda 2013 m. apgintoje humanitarinių mokslų daktaro disertacijoje analizavo lietuviškosios istorijos pokyčius 1904-1940 m. ir istoriko profesijos sklaidos tiriamuoju laikotarpiu problematiką ${ }^{60}$.

\footnotetext{
${ }^{54}$ Black, J. Rethinking Military History. London, New York, 2004, pp. 6-8.

${ }^{55}$ Rakutis, V. XVIII a. Lietuvos karo istorijos tyrimų apžvalga. Karo archyvas, 2003, t. XVIII, p. 307-322; Lesčius, V. Dèl Lietuvos kariuomenès kūrimo ir Nepriklausomybès kovų istoriografijos. Lietuvos istorijos studijos, 2002, t. X, p. 35-50; Vaičenonis, J. 1921-1940 m. laikotarpio Lietuvos kariuomenès tyrimai. Karo archyvas, 2003, t. XVIII, p. 339-354; Pocius, M. 1944-1953 metu partizaninio karo Lietuvoje istoriografija. Istorija, 2006, t. LXIV, p. 52-64; Vitkūnas, M. Archeologijos mokslo vaidmuo Lietuvos karo istorijos tyrimuose. Karo archyvas, 2003, t. XVIII, p. 296-306.

${ }^{56}$ Selenis, V. Lietuvos istoriku bendrija 1918-1944 metais: kolektyvinés biografijos tyrimas. Vilnius, 2007.

${ }^{57}$ Ragauskas, A. Keletas pastabų dèl istorijos metodologijos tarpukario Lietuvoje. Lietuvių kataliku mokslo akademijos metraštis, 2001, t. XIX, p. 59-70.

${ }^{58}$ Lasinskas, P. Istorijos mokslas Vytauto Didžiojo universitete 1922-1940 metais. Vilnius, 2004.

${ }^{59}$ Juzefovičius, R. Istorinė švietėjiška karo mokslų draugijos veikla 1923-1933. Karo archyvas, 2002, t. XVII, p. 181-194.

${ }^{60}$ Gieda, A. Istoriografija ir visuomene: istorika, istoriko profesijos ir istorinès kultūros aspektai Lietuvoje 1904-1940 m. [daktaro disertacija]. Vilnius, 2013.
} 
Istorikas J. Vaičenonis, aptaręs karo istorijos tyrimų 1918-2008 m. organizavimo problemas, apie tarpukarị rašè: „Kartu su Lietuvos valstybingumo atkūrimu $1918 \mathrm{~m}$. atsirado sąlygos ir Lietuvos karo istorijos tyrinèjimams. Laikotarpi nuo $1918 \mathrm{~m}$. iki sovietinès okupacijos galètume suskirstyti į du tarpsnius. Pirmąji, apimantị 1921-1926 metus, galima būtų ìvardinti kaip parengiamąji, o antrąji, kuris prasideda 1927 ir baigiasi 1940 m. - konkrečių ir tikslinių karo istorijos darbų igyvendinimo laikotarpiu. "61 Tačiau dera pažymèti, kad Lietuvos karo istorijos tyrimuose stokojama „homeriškojo nešališkumo““2, t. y. tyrimai dažnai atliekami vertinant reiškinius tik iš savo perspektyvos, lygiagrečiai nebandant objektyviai pažvelgti, o kas gi vyko „kitoje fronto linijos“ pusèje.

Istorikų bendruomenei turètų būti būdinga autorefleksija, siekis nustatyti, kas nuveikta ir kokios yra tolesnès galimybès, pagaliau - „kas mes esame“ ir „kuo užsiimame“63. 1938-1939 m. Jonas Matusas ir Zenonas Ivinskis ${ }^{64}$ apžvelgè ir îvertino dviejų nepriklausomybės dešimtmečių Lietuvos istoriografiją, apskritai istorijos mokslo padètį. Z. Ivinskis kritiškai ją ivvertino, teigdamas, kad „charakterizuojant mūsų esamą istorijos kryptị, reikia pasakyti, kad ji iš romantizmo prieglobsčio dar nėra visiškai išsilaisvinusi“ ir „dažnai mūsų darbas panašus yra i̇ prie didelès krūvos besikrapštantị žmogelị, kuris nemato, kas yra anoje jos pusėje ${ }^{{ }_{65}}$. J. Matusas pozityviau apibendrino, teigdamas, kad „Lietuvos istorijos mokslas per 20 metų padarè nemažą pažangą", tai pagrịsdamas išvardijo istorikus

${ }^{61}$ Vaičenonis, J. Lietuvos karo istorijos tyrimų organizavimas 1918-2008 metais. Istorija, 2009 , t. LXXIII, p. 63.

${ }^{62}$ Hannah Arendt teigimu, „nešališkumas, o kartu ir visa tikroji istoriografija atsirado tada, kai Homeras nusprendè apdainuoti ne tik achajų, bet ir trojẻnų žygdarbius bei pašlovinti ne tik Achilo didybę, bet ir Hektoro šaunumą. Šitoks homeriškas nešališkumas, perimtas Herodoto, <...> vis dar yra aukščiausias mums žinomas objektyvumo tipas“: Arendt, H. Tarp praeities ir ateities. Vilnius, 1995, p. 60.

${ }^{63}$ Gieda, A.; Švedas, A. Kuo svarbi istoriografijos istorija? Istorikų identiteto problemos Lietuvos istoriografijoje. Lietuvos istorijos studijos, Nr. 16, 2005, p. 42-47; Dragenytè, R. Šiuolaikinès istoriografijos pokyčiai: Jörno Rüseno koncepcija. Senosios Lietuvos literatūra, 30 knyga, 2010, p. 277.

${ }^{64}$ Plačiau apie Z. Ivinskį žr.: Selenis, V. Zenonas Ivinskis $1918-1940$ metų istorikų bendrijos kontekste. Soter, 2009, Nr. 29 (57), p. 85-97.

${ }^{65}$ Ivinskis, Z. Lietuvos istorija romantizmo metu ir dabar. Lietuviu kataliku mokslo akademijos suvažiavimo darbai, 1940, t. 3, p. 321-340. 
ir jų darbus, išskyrè 2 muziejus ir 4 tęstinius leidinius istorijos tematika: Mūsų senové, Praeitis, Senové ir Karo archyvas ${ }^{66}$. Tačiau ar tai taikoma ir karo istorijai? Anot politikos mokslų atstovo Deivido Šlekio, Lietuvos istorikai ir tarpukariu, ir XXI a. susiduria su tomis pačiomis problemomis, pirmiausia - su valstybės institucijų, ypač Krašto apsaugos ministerijos, polinkiu palaikyti „senajji istorini pasakojimą“, kas istorijos vertinimo prasme rodo, kad „istrigta laike ${ }^{\text {"67 }}$, tačiau atitinka vieną iš ịvardijamų „pavojų“ istorijos mokslui - pagarba tradicijoms ${ }^{68}$. Galbūt ir galima būtų sutikti, kad krašto apsaugos sistemoje esama probleminių aspektų istorijos apskritai ir karo istorijos atskirai vertinimo ir tyrimų kontekste, tačiau drịstume suabejoti, kad esama padètis a priori analogiška tarpukariu susiklosčiusiai paděčiai, kai karo istorijai buvo skiriamas išskirtinis dèmesys įvairiais lygmenimis.

Johnas Toshas pabrèžia, kad istorikai yra žmonijos kultūrinio palikimo saugotojai ir istorijos tyrimai vykdytini nepaisant nūdienos aktualijų, nes tada kyla jų politizavimo grèsmè, kartu tik gerai ịsisąmoninta bendra istorine praeitis mobilizuoja bendruomenes efektyviai veikti ${ }^{69}$. Vokietijos istoriko Ernsto Bernheimo teigimu, istorijos moksliniai tyrimai atvèrè plačias galimybes komparatyvistikai ${ }^{70}$. Taigi Lietuvos istorijos tyrimų analizè igalina nustatyti ir ịvertinti esamą padètị ir nubrèžti galimas perspektyvas. Analizuojant Lietuvos karo istorijos tyrimus pažymètinas įdomus faktas, kad buvusio Latvijos kariuomenès vado, kelių knygų apie Latvijos nepriklausomybès karą autoriaus gen. Mārtiņšo Peniķio ${ }^{71}$ dèka 1938 m. buvo išleistas Latvijos nepriklausomybès karo istorijos dvi-

\footnotetext{
${ }^{66}$ Matusas, J. Kiek pažengė Lietuvos istorijos mokslas. Pasaulio lietuvis, 1938, balandžio 1, Nr. 7 (10), p. 147-148.

67 Šlekys, D. Mąslaus Vyčio beieškant. Lietuviškos karinès minties raida ir būkle po nepriklausomybès atkūrimo (1990-2014). Vilnius, 2015, p. 49-51.

68 Тош, Д. Стремление к истине. Как овладеть мастерством историка. Москва, 2000, c. 21-29.

${ }^{69}$ Ten pat, c. $12-56$.

${ }^{70}$ Бернгейм, Э. Введение в историческую науку. Москва, 2011, с. 6.

${ }^{71}$ Penikikis, M. Latvijas armijas sākums un vinas darbība lìdz 1919. gada 8. oktobrim. Rīga, 1927; Peniḳis, M. Latvijas nacionālās armijas cīnas 1919 vasarā un rudenī. Rīga, 1931; Penikikis, M. Latvijas armijas sākums un cīnas Latvijā lìdz 1919 jūlijam. Rīga, 1932.
} 
tomis (jis buvo šio leidinio vyriausiasis redaktorius) ${ }^{72}$. Estijoje prie kariuomenès štabo veikęs Nepriklausomybès karo istorijos komitetas (est. Vabadussõja Ajaloo Komitete) 1937-1939 m. taip pat išleido savo šalies nepriklausomybès karo istorijos du tomus ${ }^{73}$. Ir Latvijoje, ir Estijoje šios knygos, atkūrus nepriklausomybę, buvo perleistos. Analogiško pobūdžio darbų Lietuvoje atsirado vèliau ${ }^{74}$, paminètinos Vytauto Lesčiaus knygos ${ }^{75}$, pasirodžiusios tuo metu, kai latviai ir estai pakartotinai leido ${ }^{76}$ iš esmès analogiškus tarpukario karo istorijos darbus. Kyla klausimas, kodèl Lietuvoje tarpukariu nebuvo parašyta ir išleista analitinių tokio lygio karo istorijos darbų apie Nepriklausomybès kovas, nors tuo metu veikè Karo mokslų draugijos (KMD) Istorijos sekcija, o Kariuomenès štabe buvo ¡kurta Istorijos dalis ${ }^{77}$.

Atsižvelgiant $\mathfrak{i}$ Lietuvoje esamą ir toliau augantị karo istorijos mokslinių tyrimų potencialą, siekį reflektuoti ir suvokti, „kas esame“ ir „ką nuveikème“, taip pat atsakyti ị klausimą, kam karo istorijos tyrimai galètų ir turètų būti aktualiausi, kas yra jų pagrindinis užsakovas, kodèl Latvijoje ir Estijoje atkūrus valstybingumą karo istorijos veikalai buvo perleidžiami, o Lietuvoje - tik rašomi, aktualu atlikti karo istorijos svarbos tarpukariu Lietuvoje tyrimą. Mėginant konkrečiau apsibrèžti tyrimo ribas ir siekiant jo gelmès, bus laikomasi prielaidos, kad būtent kariuomenè yra (buvo) pagrindinis karo istorijos tyrimų iniciatorius ir vartotojas. Tačiau ar iš tikrųjų atkurtosios Lietuvos Respublikos krašto apsaugos sistema de facto yra karo istorijos ir apskritai istorijos naujausių tyrimų vartotoja? Ar vadovaujasi Vinco Kudirkos Tautiškoje giesmejje įtvirtintu priesaku: „Iš

\footnotetext{
${ }^{72}$ Latvijas atbrīvošanas kara vēsture. Virsred. M. Peniḳis. 1-2 sēj. Rīga, 1938.

${ }^{73}$ Eesti Vabadussõda 1918-1920, t. I, toimetanud H. Ots ja S. Laider. Tallinn, 1937; Eesti Vabadussõda 1918-1920, t. II, toimetanud H. Ots ja S. Laider. Tallinn, 1939.

${ }^{74}$ Mažesnès apimties darbų būta ir tarpukariu: Petras Ruseckas buvo parengęs tekstą, skirtą Nepriklausomybės kovoms nušviesti, tačiau nespejo jo išspausdinti. O išeivijoje pasirodè Kazio Ališausko ir Antano Ruškos tritomis (1972, 1981 ir 1982 m.) Kovose dèl Lietuvos nepriklausomybès.

${ }^{75}$ Lesčius, V. Lietuvos kariuomene 1918-1920. Vilnius, 1998; Lesčius, V. Lietuvos kariuomené Nepriklausomybès kovose 1918-1920. Vilnius, 2004.

${ }^{76}$ Estijoje 1996 ir 1997 m., o Latvijoje 2006 m.

${ }^{77}$ Institucines karo istorijos tyrimų tarpukariu problemas šio straipsnio autorius analizuos kitoje, jau rengiamoje, publikacijoje.
} 
praeities Tavo sūnūs / Te stiprybę semia“, t. y. ar praeitis yra tas „šaltinis“, iš kurio kas nors semiama, o jei taip - tai kas, kaip ir ką semia? Abejones pagrindžia menka karo istorijos vieta karininkų rengimo ir kvalifikacijos kèlimo sistemoje, taip pat tokie atvejai, kai Lietuvos didieji kunigaikščiai transformuojami $\mathfrak{i}$ "karalius“ arba Karaliaus Mindaugo bataliono kariai tampa „husarais“, nors nèra jokio istorinio pagrindimo. Be to, ir karinio planavimo srityje karo istorija, tiketina, nevaidina beveik jokio vaidmens, nes nei Lietuvos kariuomenès štabuose, nei Mokymo ir doktrinu valdyboje nèra jokio karo istorijos padalinio, tiriančio ir analizuojančio Lietuvos ginkluotajai gynybai aktualius nacionalinius ir pasaulinius karo istorijos atvejus. Todèl ir karo istorija netampa medžiaga kūrybiniame karinio planavimo procese, renkantis tik JAV karo mokyklos adeptų ke$\mathrm{lią}^{78}$. Tik Generolo Jono Žemaičio Lietuvos karo akademijoje veikia Karo istorijos centras ir Krašto apsaugos ministerijai pavaldus Vytauto Didžiojo karo muziejus.

Šio tyrimo tikslas - ivvertinti karo istorijos svarbą tarpukariu Lietuvos kariuomenei. Uždaviniai: 1) išnagrinèti, kokia buvo karo istorijos tyrimų reikšmė; 2) išanalizuoti susidomejjimo karo istorija Lietuvos kariuomenejje raišką; 3 ) atskleisti, kokios metodologinès rekomendacijos buvo teikiamos atliekantiems karo istorijos tyrimus. Chronologinès ribos apima tarpukario laikotarpi. Tyrime taikomi turinio analizès, sintezès ir deskreptyvinis metodai, siekiant atskleisti Lietuvos kariuomenès požiūrị Ł̇ karo istoriją ir teiktas metodologines tokio pobūdžio tyrimų vykdymo rekomendacijas.

I.

1921 m. Karyje būsimasis užsienio reikalų ministras vyr. ltn. Juozas Urbšys, atkreipdamas demesị $\mathfrak{i}$ karo istorijos svarbą, išskyrè tris aspektus: 1) objektyvų karo istorijos faktų fiksavimą; 2) karo istorijos, kaip karo mokslo medžiagos, reikšmę ir 3) istorijos, kaip motyvuojančios piliečius su ginklu stoti ginti Tèvynès, ugdytojos, kuri, anot autoriaus, reikalinga

\footnotetext{
78 Šlekys, D. Amerikietiškosios kariavimo tradicijos svarba ir keliamos problemos. Lietuvos metiné strategine apžvalga 2007. Vilnius, 2008, p. 25-48.
} 
„karžygystės kultui sudaryti“79. Taigi, karo istorija remiantis buvo kuriamas savotiškas karžygystės kultas ${ }^{80}$. Karinèje spaudoje rašyta, kad „Lietuvos karžygys dar ir senoveje buvo visam pasauliui žinomas kaipo narsus, sąžiningas, atsidavęs savo vadams vyras. Jo vardą gerbè net didžiausi Lietuvos priešai. $O$ gerbè dèl to, kad lietuvis mokejjo garbingai elgtis. Jis niekad nebėgdavo iš kautynių lauko, jis niekad nebijodavo priešų, jis, mylèdamas savo tèvynę iš visos širdies, aukavo jai savo kraują" ${ }^{\text {"81 }}$. Akcentuota, kad „mirti už tèvynę yra pati brangiausia auka. Tokią auką gali duoti tik karžygys. O tapti karžygiu pirmenybė tenka kariui“" ${ }^{82}$ ir „tikras karžygys“ žūva „su ginklu rankoje“83. Be to, „tikras karžygys kovoj apie dovanas negalvoja, tik apie pareigas. Bet kada už tas savo pareigas, su pasiaukojimu atliktas, gauna garbingas dovanas, jis jas su džiaugsmu sutinka ir jas gerbia, nesuteršdamas blogais darbais bei tuščiais pasididžiavimais “ ${ }^{{ }_{84}}$.

Formuota nuostata - „lietuvi, ịsidèk giliai ị širdị sau ši gražų posakį: "Saldu ir garbinga už tèvynę mirti“, nes „nebus baisu mirti už tėvynę, bet priešingai, tau bus malonu, tu mirsi kaip karžygys, ir už tavo drąsą minès tave kartų kartos “85. Žūtis kovoje už tèvynę "garantavo nemirtingumą“. 1936 m. Vẻlinių išvakarèse Trimite rašyta: „Visi žuvę ar mirę šauliai tebegyvena mūsų tarpe... Gyvi mums savo karžygišku pavyzdžiu yra amžino atminimo žuvę šauliai partizanai: Aleksandras Vainauskas, Vincas Dovydaitis, Algirdas Jasaitis ir visa eilè kitų. " ${ }^{\text {86 }}$ Teiginys paremtas koncepcija, kad tautą sudaro gyvieji ir mirusieji. Tai buvo vienas iš trijų pagrindiniais įvardytų karo istorijos uždavinių formuojant ir palaikant didvyrių-karžygių mitą, siekiant užtikrinti jǔ žygiu atminimo nemirtingumą.

Ideja koreliuoja su Povilo Štuopio ${ }^{87}$ (kuris istorijos studijas baigė VDU

${ }^{79}$ Urbšys, [J.] Karo istorijos klausimu. Karys, 1921, sausio 8, Nr. 1 (85), p. 2-3.

${ }^{80}$ Pvz., 1926 m. išleista knyga: Dineika, K. Lietuvos karžygys Antanas Juozapavičius. Kaunas, 1926.

${ }^{81}$ Varinis, J. Iš savanorio atsiminimų. Karys, 1926, lapkričio 10-16, Nr. 46 (390), p. 380.

${ }^{82}$ Mirti už tèvynę... Karys, 1927, liepos 13-19, Nr. 28 (424), p. 259.

${ }^{83}$ Žemaitis, J. Veiverių kapai prislègė tris karžygių kūnus. Kardas, 1929, gegužès 30, Nr. 21 (521), p. 359.

${ }^{84}$ St. Vyties Kryžiaus ordino šventès proga. Karys, 1930, lapkričio 20, Nr. 47 (599), p. 941.

${ }^{85}$ J-k-s, K. Savo krašto reikalu. Karys, 1930, sausio 1, Nr. 1 (553), p. 9.

${ }^{86}$ Jie gyvena tarpe mūsų... Trimitas, 1936, spalio 29, Nr. 44 (829), p. 1042.

${ }^{87}$ Gimęs 1907 m., įstojo ị universitetą 1928 m., 1937 m. VDU baigė istorijos studijas, 
ir aktyviai bendradarbiavo spaudoje ${ }^{88}$, mokytojavo, buvo gimnazijos direktorius) pozicija, išreikšta tarpukariu, kad mokslas - tai „galingiausia pasaka“ ir „nuomonè apie tiesą“, o mokslininkai - „burtininkai ir magai“. Tačiau mokslas gali sustiprinti gyvenimo energiją, kuri „pakels ị erdves“, svarbu, kad istorija būtų ikvepianti ir uždeganti, net jei ji ir „nemoksliška“. Todèl „mūsų praeitis turès pasiaukoti ateičiai, kitu atveju - mes jos

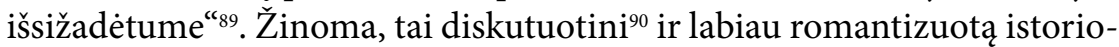
grafinę tradiciją atliepiantys teiginiai.

1932 m. gen. št. plk. Vladas Skorupskis, remdamasis C. von Clausewitzu, plk. Aleksandro Uspenskio knygos recenzijoje rašė, kad „karas reikalingas tam, kad vèliau ką nors apie ji parašytume, jị išstudijuotume, kad mokètume vèl kariauti“" ${ }^{\text {“1 }}$ JAV konfederatų gen. Robertas Edwardas Lee yra pasakęs - gerai, kad karas toks baisus, nes kitaip mes ji mylètume pernelyg stipriai ${ }^{22}$. Jeano Nortono Cru teigimu, „žmogus visada didžiavosi karu. Jis pagražindavo patị mūšio aktą. Gražiomis spalvomis priešè kavaleriją ir durtuvų atakas. Jis apdovanodavo karius antžmogiškais jausmais: nenugalima narsa, degančiu noru kautis“ ir t. t.93 Žinoma, tai labai idealizuotas vaizdinys, gerokai besiskiriantis nuo realybès, o ir

dirbo mokytoju, gimnazijos direktoriumi. Plačiau žr.: Mokytojo Povilo Štuopio asmens byla. $L C V A$, f. 391 , ap. 7, b. 5573, 1. 1-40.

88 Švedas, A. Istoriko teritorija (II). Tekstai kaip gairès [2016 06 01]. http:// literaturairmenas.lt/2015-03-13-nr-3512/2397-publicistika/3804-aurimas-svedasistoriko-teritorija-ii-tekstai-kaip-gaires.

${ }^{89}$ Štuopis, P. Istorijos stebuklai ir istorikai (fragmentai). Naujoji Romuva, 1932, gegužès 15, Nr. 20 (72), p. 462.

${ }^{90}$ Anot Hannah Arendt, XIX a. atsiradęs gamtos ir istorijos mokslų supriešinimas kartu su tariamu absoliučiu gamtotyrininkų objektyvumu ir tikslumu - praeitis, tai susiję su prielaidos, kad gamtos mokslų eksperimentus galima atlikti nešališkai, todèl rezultatai bus „objektyvūs“. Tačiau ir istorijos, ir gamtamokslinių tyrimų rezultatai atsako ị žmogaus iškeltus klausimus, taigi atsakymui turi itakos tyrejo pozicija, kuri tiek istoriko, tiek fiziko yra „subjektyvi“: Arendt, H. Tarp praeities ir ateities. Vilnius, 1995, p. 57-58.

91 Skorupskis, V. A. Uspenskio „Kare“. Naujoji Romuva, 1932, gegužès 15, Nr. 20 (72), p. 477.

92 Кревельд ван, М. Трансбормация войны. Москва, 2008, с. 243.

${ }^{93}$ Cituojama pagal: Головин, Н. Н. Наука о войне. Избранные сочинения. Москва, 2008, c. 46-48; [remiamasi Cru, J. N. Témoins: essai d'analyse et de critique des souvenirs de combattants édités en français de 1915 à 1928. Paris, 1929]. 
ne visi karo vadai ir karybos teoretikai žavisi karu ${ }^{94}$. Irenologijos atstovai susižavẻjimą kautynemis ${ }^{95}$ galètų apibūdinti net kaip karo kurstymą. JAV politologas, ekonomistas, istorikas, karo strategas Edwardas Nicolae Luttwakas, turintis dvi skirtingas nuomones apie karo istorijos tyrimų naudą ir metodologinę prieigą, palygino plačiai žinomos sentencijos $S i$ vis pacem, para bellum, perfrazuotos kaip Si vis pacem, para pacem irenologijos - taikos studijų (peace studies) atstovams, kurie teigia, kad taiką reikia tyrinèti kaip atskirą reiškini ir aktyviai dirbti dèl jos ${ }^{96}$. Taigi kyla klausimas, kokia bus istorijos tyrimų kryptis - formuojamoji, pirmiausia akcentuojant tyrimus, remiančius valstybès politiką, ir stiprinant Lietuvos visuomenès tapatybę pagal sprendimų prièmimų galią turinčių asmenų supratimą, ar pliuralistinè, atspindinti požiūrių ir nuomonių ịvairovę visuomeneje, su kritinio vertinimo akcentais?

Tenka pabrèžti, kad karo istorijos ugdomojo pobūdžio ir tautiškai patriotiniu naratyvu paremti tyrimai gali pateikti netikslius atsakymus, o juos ekstrapoliavus naujiems gynybos politikos sprendimams pagristi, ateityje turèti katastrofiškų padarinių valstybės karinei gynybai ${ }^{97}$. XIX a. gen. Henrikas Leeras ${ }^{98}$ pabrèžè karinès analizės karo istorijoje svarbą, nes tik tokiu atveju karo istorijos darbai turi vertę, ir nurode šio dalyko išskirtinę vietą greta karybos teorijos (karo filosofijos). Todèl tik kritiniu metodu paremtos analizès išvados (hipotezès, patikrintos atlikus nuodugnią ir plačią analizę) gali būti tvirtas karo mokslo pagrindas ${ }^{99}$. Gen. Nikolajus

\footnotetext{
${ }^{94}$ Pvz., Karlas von Österreichas-Teschenas (Habsburgas) pažymėjo, kad karas - tai didžiausias blogis, kuris tik gali užklupti valstybę ar tautą: Габсбург, К. Основы высшего военного искусства. Германская военная мысль. Сос. К. А. Залесский. Москва, 2012, c. 80 .

95 Plačiau žr.: Кревельд, ван М. Трансформация войны. Москва, 2008, с. 241-256.

96 Люттвак, Э. Стратегия. Логика войны и мира. Москва, 2012, с. 15.

${ }^{97}$ Jokubauskas, V.; Vaičenonis, J.; Vareikis, V.; Vitkus, H. Valia priešintis. Paramilitarizmas ir Lietuvos karinio saugumo problemos. Sud. H. Vitkus, V. Vareikis. Klaipėda, 2015, p. $16-17$.

${ }^{98}$ Rusijos generolas, Nikolajaus generalinio štabo akademijos karo meno profesorius ir jos viršininkas (Генрих Антонович Леер, 1829-1904 m.).

99 Леер, Г. А. Опьт критико-исторического исследования законов искусства ведения войны. Санкт-Петербург, 1869, с. i-iii.
} 
Golovinas $^{100}$ tarpukariu aptare karo istorijos mokslo padèti, remdamasis pavyzdžiais konstatavo, kad jis yra politizuotas, o šios šakos istoriku darbuose, jei apsiribojama karo meno „aptarnavimu“, remiantis štabų dokumentais, dažniausiai aprašyta, „kas kur ejjo ir kur bei kaip kovėsi“. Generolo nuomone, karo istorija turi apimti platesnị tyrimo lauką, t. y. kartu analizuoti socialius ir ekonominius aspektus, karių kasdienybę, nes, pasak jo, tik fronte kovojantys kariai, o ne štabuose sèdintys ir raportus rašantys karininkai žino, kas yra karas ${ }^{101}$. Kitas tarpukario karybos teoretikas gen. Aleksandras Svechinas ${ }^{102}$ rašè, kad be karo istorijos pavyzdžių kyla grèsmė pasiklysti abstrakčiose karybos teorijose. Jo teigimu, strategiškai mąstyti ir planuoti neįmanoma neišmanant karo istorijos, todèl pabrèžè savarankiškų analizių, o ne šabloninių sintezių studijavimo svarbą ${ }^{103}$. Beje, abu šie autoriai, karo istorijai teikę išskirtinę reikšmę, buvo žinomi tarpukariu Lietuvos kariuomeneje ir jais remtasi.

Karo istorija yra karo mokslų dalis, gal net viena iš svarbiausių, nes tai - medžiaga, strategijos, operacijų meno ir taktikos, apskritai karybos pagrindas, kadangi šioje srityje eksperimentas neįmanomas. Tarpukariu pažymėta, kad „karo istorijos pavyzdžiai duoda strategijai atskiras „kampanijas“, nes strategijos pagrindai nekinta ${ }^{104}$. Lietuvos kariuomenès Generalinio štabo valdybos viršininkas gen. ltn. Zenonas Gerulaitis $1932 \mathrm{~m}$. išleistame Karo istorijos įvade išdèstè, kodèl karo istorija dèstoma karininkams. Generolo teigimu, dėstant kursą nesiekiama suteikti žinių apie „visus praeities karo faktus, nes tai, pirmiausia, neįmanoma apskritai, o

\footnotetext{
${ }^{100}$ Rusijos imperijos kariuomenės generolas, Nikolajaus generalinio štabo karo akademijos profesorius, Pirmojo pasaulinio karo dalyvis, tarpukariu gyveno emigracijoje, gausiai rašè karo istorijos ir karybos temomis (Никола́й Никола́евич Голови́н 1875-1944m.).

101 Головин, Н. Н. Наука о войне. Избранные сочинения. Москва, 2008, с. 46-66.

${ }^{102}$ Rusijos imperijos ir SSRS generolas, karybos teoretikas ir pedagogas (Александр Андреевич Свечин 1878-1938 m., sušaudytas Stalino represijų metu), žymių karybos veikalu Karo meno istorija, Karo meno evoliucija, Strategija ir kt. autorius: Свечин, А. А. История военного искусства [3 части]. Москва, 1922-1923; Свечин, А. А. Стратегия. Москва, 1926: Свечин, А. А. Эволюиия военного искусства [2 тома]. Москва, 1927-1928.

103 Свечин, А. Стратегия. Москва, 1927, с. 23-24.

${ }^{104}$ Strategija - operacija - taktika (iš vokiečių kalbos išvertė kpt. Žlabis). Kardas, 1930, liepa, Nr. 7 (15), p. 102.
} 
be to - nereikalinga ir net kenksminga, kaip bergždžias smegenims balastas“. Kurso tikslas - karininkams atskleisti, „kuo praeities karų faktų pažinimas naudingas besirengiant ateities karams, kaip žinios apie praeiti eksploatuojamos ateičiai“ užtikrinti. Antrasis kurso uždavinys buvo karo istorijos faktais „pagrịsti tą karo teoriją, kuri čia [Karo mokykloje - V. J.] jums dažnai teikiama plikos, vien logika paremtos spekuliacijos forma“, nes karo istorija suteikia karo teorijos medžiagos, taigi abi disciplinos labai glaudžiai susijusios. Karo istorija neįmanoma be karo teorijos, nes ji - „karo istorijos kvintesencija, „karo istorijos filosofija“105.

\section{2 m. Karde buvo samprotaujama:}

„Karo istorija yra kiekvienos tautos gyvybès, tautos teisių gynimo ir tautos noro bei aspiracijų atspindys. Neteisinga būtų manyti, kad karo ir bendroji istorija yra vien $\mathfrak{i}$ praeitị nukreiptas mokslas. Istorija nèra tik praeities dokumentų rinkinys ir mąstymas apie praeiti. Teisingai suprastas istorijos mokslas apima praeitị, dabartị ir ateitị, jis nurodo ateities darbo kelius ir šaukte šaukia veikti. Todèl istorijos ịvykiais, faktais nepakanka vien gèrètis ar juos pasmerkti. Kiek mokèsim įvertinti praeitį, tiek suprasim ne tik patys save, bet kartu savo dabarties ir ateities uždavinius. <...> Kas neturi istoriškų pažiūrų i šių dienų dalykus, tas negali suprasti ir šių dienų uždavinių. Dabartis remiasi praeitimi ir nurodo ateities kelius. "

Šiuos ir kitus viešus samprotavimus, siekiant aktualizuoti karo mokslų ir karo istorijos studijavimą, galima sieti ir su Vytauto Didžiojo karininkų kursų Generalinio štabo skyriaus įkūrimu.

1931 m. Kariuomenès vyriausiojo štabo viršininkas gen. ltn. Petras Kubiliūnas, kalbėdamas aukštesniųjų karininkų kursų iškilmėse, pabrèžè: „Mes turime susidaryti savo karo meno taktiką, bet ne aklai kopijuoti iš kitu. Taktika turi būti pritaikyta kariuomenès ypatybėms ir geografinei aplinkumai. Kiekviena tautos kariuomenè, net kiekviena žymesnė operacija turi savo atskirą taktiką. "107 Po metų - 1932-aisiais - gen. ltn. P. Kubiliūnas Generalinio štabo karininkų kursų atidarymo kalboje pabrèžè:

\footnotetext{
${ }^{105}$ Gerulaitis, Z. Karo istorijos juvadas. Kaunas, 1932, p. 1-2.

106 Ž-tis, S. Karo istorijos ir karo geografijos studijų reikalu. Kardas, 1932, sausis, Nr. 1 (33), p. 2.

${ }^{107}$ Nemunèlis, V. Mūsų kariuomenès karininkų korpo išsirutuliojimas. Karys, 1931, birželio 18, Nr. 25 (629), p. 494.
} 
„Karo istorija mums duoda galimybės sekti, kaip palaipsniui vystėsi kariuomenès organizacija ir kaip sulig to tvarkèsi ir tobulèjo kariuomenès vadovybe்“. Toliau generolas apžvelge karo istoriją nuo Napoleono laikų, akcentuodamas karybos pokyčius, o ypač karinių vienetų koordinavimo sudètingèjimą ${ }^{108} .1933 \mathrm{~m}$. Vyriausiojo štabo aplinkraštyje kariuomenei, pasirašytame gen. ltn. P. Kubiliūno, išdèstyta, kad „iki šiol opesni kariuomenès tvarkymo darbai neleido užsiimti mūsų nepriklausomybès karų istorija, nežiūrint, kad tokios istorijos svarba yra labai didelè. Artimoje ateityje bus pradètos mūsų nepriklausomybès karų studijos, todèl tenka sudaryti būsimiems darbams pagrindą“. Taip pat buvo nurodyta Generalinio štabo valdybos III skyriui pristatyti: 1) visų 1919-1923 m. operatyvinių dokumentų originalus; 2) visą daliniuose esančią karo istorijos parengtą ar publikuotą medžiagą; 3) atsiminimus. Išskirtinis dèmesys buvo skirtas atsiminimų rašymui ir rinkimui, teikti nurodymai, kokie apsektai turètų būti juose atskleidžiami, akcentuojama būtinybè juose atskirti faktus nuo autorių subjektyvių spėliojimų ${ }^{109}$. Gen. ltn. P. Kubiliūnas XX a. 4-ojo dešimtmečio pradžioje pabrèžè, kad kitų šalių karybos kopijavimas nepriimtinas, ir savos karo meno mokyklos formavimo būtinumą, o tam neišvengiamai reikejo pasitekti karo istorijos tyrimus.

Būsimas Lietuvos kariuomenès vadas mjr. Stasys Raštikis 19301932 m. studijavo Vokietijoje ir savo atsiminimuose rašè, kad „karo istorijos dèstymas vokiečių generalinio štabo akademijoje iš pagrindų skyrèsi nuo karo istorijos studijų kitų valstybių generalinio štabo akademijose“, nes Vokietijoje teorinių paskaitų nebuvo, karininkai gaudavo nurodymus, kokius karo istorijos veikalus skaityti, o vėliau vykdavo jų aptarimai, analizès ir taktinès pratybos - „karo žaidimai“. Taip pat buvo organizuojamos lauko ekspedicijos, jose karininkai spręsdavo karo istorijos ir taktikos uždavinius. Taip per karo istorijos paskaitas buvo lavinamas karininkų analitinis mąstymas, gebejimas priimti deramus sprendimus ${ }^{110}$.

Ši patirtis karininkui paliko gilų ìspūdị. Jau grịžęs ị Lietuvą, 1934 m. gen. št. plk. ltn. S. Raštikis rašè, kad, norint tapti „geru karo vadu,

${ }^{108}$ Pone Ministre, gerbiamieji ponai karininkai, gen. ltn. Kubiliūnas. LCVA, f. 929, ap. 6, b.186, 1. 150-156.

${ }^{109}$ Vyriausiojo štabo $1933 \mathrm{~m}$. vasario 11 d. aplinkraštis. LCVA, f. 384, ap. 5, b. 24, 1. 7-8. ${ }^{110}$ Raštikis, S. Kovose dèl Lietuvos. I t. Vilnius, 1990, p. 262-263. 
reikalingi ne tik igimti karo vado gabumai, ne tik geras patyrimas ir taktiškas pasirengimas, bet ir karo istorijos žinojimas, nes karybos istorija yra jei ne pati svarbiausia, tai tikrai viena iš svarbiausių karo mokslo šakų " [išskirta tekste - V. J.] ${ }^{111}$. Būsimas generolas pažymèjo, kad net pats naujausias ir moderniausias kariuomenès statutas bus tik sausų straipsnių rinkinys, jeigu jame nebus pateikta praktinių, patyrimu paremtų pavyzdžių su paaiškinimais karo istorijos kontekste. Jis pabrèžè, kad taikos metu dauguma karininkų nesidomi karo istorija ir jos nevertina, nes mano, kad tai - tik aukštụjų karininkų užsièmimas, ir tai būdinga visų šalių kariuomenèms, o šios padeties kaltininkai yra istorikai ir karo istorijos dèstytojai, kurie nesudomina karių ir nederamai pateikia istorijos kursą. Kita nesidomejjimo karo istorija priežastis, pasak karininko, yra karo istorijos rašytojų ir dėstytojų (jaunų ir nepatyrusių generalinio štabo kapitonų, majorų ir pulkininkų leitenantų) „didelè drąsa nagrinejjant vieną ar kitą istorijos pavyzdị“. Trečioji - kad jaunesnieji karininkai karo istorijos veikaluose mažai randa praktinių pavyzdžių, susijusių su kuopų ar batalionų taktine veikla, nes knygose dažniausiai gilinamasi ị armijų, korpusų ir divizijų veiksmus. Tačiau, S. Raštikio nuomone, visi karininkai turi būti supažindinti su karo istorija, ja domètis ir analizuoti, kad perprastų karybą. Negana studijuoti žemèlapius, dalyvauti mokymuose poligonuose ir manevruose, kadangi tai „nèra tikras karo laukas. Taikos metu tokio tikrųjų kautynių lauko ir negali būti"112. Būsimas kariuomenès vadas labai nuodugniai aptarè karo istorijos reikšmę kariuomenei, taip lyg ir nubréždamas ateities veiklos gaires. O savo atsiminimuose rašè, kad tuo metu (1932-1934 m.) jam pavyko Mūsu žinynui parašyti savo

\footnotetext{
111 Straipsnį autorius pradeda dviem žymių karvedžių citatomis: (Napoleono) „Kariaukite kaip Aleksandras, Hanibalas, Cezaris, Gustavas Adolfas, Tiurenas, Princas Eugenijus ir Fridrichas. Skaitykite jų vadovautų 88-erių karo žygių istoriją. Skaitykite ją daug kartų ir imkite iš jos pavyzdžius. Tai yra vi en in telis [išskirta tekste - V. J.] kelias suprasti ir ìsigilinti ị karybos paslaptis ir pasidaryti garsiuoju karo vadu.“; (Alfredo von Schlieffeno) „Prieš kiekvieną, norintị būti karo vadu, guli knyga, pavadinta „Karo istorija“. Ji prasideda pirmosios pasaulyje Kaino ir Abelio kovos aprašymu ir toli gražu dar nebaigta. “Žr.: Raštikis, S. Karo istorijos reikšmè ir jos dèstymo metodas vokiečių gen. št. mokykloje. Mūsu žinynas, 1934, t. XXVI, Nr. 109, p. 289.

${ }^{112}$ Raštikis, S. Karo istorijos reikšmė ir jos dėstymo metodas vokiečių gen. št. mokykloje. Mūsų žinynas, 1934, t. XXVI, Nr. 109, p. 290-292.
} 
geriausius straipsnius kariuomenès mokymo, kautynių organizavimo ir karo istorijos klausimais ${ }^{113}$.

Atkreiptas demesys, kad analizuojant XX a. karo istoriją nevalia pamiršti LDK ir XIX a. karo istorijos, kuri praturtins kariuomenès tradicijas ${ }^{114}$. 1934 m. gen. št. plk. S. Raštikis teigè, kad lapkričio „23-čioji diena yra tik viena iš Lietuvos istorijos naujojo laikotarpio datų, bet ji dar nèra absoliuti mūsų kariuomenès istorijos pradžia“, todèl „iki šiol mums dar trūksta gilesnių Lietuvos karo istorijos studijų, kurių išdavoje, jei ne visi, tai bent kai kurie mūsų kariuomenès pulkai galès švęsti ne keliolikos, bet kelių dešimčių ar net kelių šimtų metų sukaktis"115. Spaudoje patriotiškai rašyta: „Ir mes, lietuviai, turim kariškai atgimti, susilyginti su garsiais senoliais. Mūsų tautos [lietuvių - V. J.] karo istorija yra labai garbinga, nes mes kariavom su rytais ir vakarais. Nors šiandien mūsų svoris nèra toks, koks buvo senovejj, bet tą skirtumą turim stengtis išlyginti dvasišku stiprumu. Mums, senovès karių vaikams, karo dalykai turi būti ypač artimi." ${ }^{116} 1939$ m. kariuomenès įsakyme deklaruota, kad kariuomenei „ypatingai rūpi“ Lietuvos karo istorijos paminklų ir tradicijų apsauga ${ }^{117}$.

1935 m. paskaitų konspekte gen. št. plk. Stasys Zaskevičius įspejo: „Karybą beorganizuodami niekada nepamirškime, kad svetimos sistemos menkai kritiškas kopijavimas mums netinka: tai primygtinai pabrèžia ne tik mūsų šalies istorija, bet ir geografija."Ir čia pat klausè - ar, Ł̇vertinę ekonominius ir geografinius veiksnius, „nejaugi galime leisti sau „liuksą“ - ištisai periminèti prancūzų, vokiečių, belgų ar čekų kariuomenès organizacijos amplitudę?" Galiausiai konstatavo, kad būtina įvertinti Lietuvos patirtị ir sąlygas, o tada spręsti, formuoti savo - nacionalinị -

\footnotetext{
${ }^{113}$ Raštikis, S. Kovose dèl Lietuvos. I t. Vilnius, 1990, p. 277.

${ }^{114}$ Balčiūnas. Mūsų karo istorijos reikalu. Karys, 1928, gruodžio 5-12, Nr. 50 (498), p. 793-794.

${ }^{115}$ Vieningumas ir stipri kariuomenè - mūsų laisvès ir nepriklausomybès laidas. Vyriausiojo štabo viršininko gen. št. plk. S. Raštikio kalba lapkričio 23 d. Trimitas, 1934, lapkričio 29, Nr. 48, p. 918.

116 Apie karą ir karingumą. Trimitas, 1939, vasario 2, Nr. 5 (946), p. 102.

1171939 m. atgavus Vilnių, karinè vadovybė Vytauto Didžiojo karo muziejui įsakè imtis visų priemonių, siekiant „užtikrinti Gedimino kalno ir Vytauto Didžiojo palaikų apsaugą ir tinkamą jiems pagarbą": Isakymas kariuomenei. Rikiuotés sritis. 1939, lapkričio 17 d., Nr. 96, p. 1.
} 
požiūrị i karybą ${ }^{118}$.

1937 m. Kariuomenės štabo III (mobilizacijos) skyriaus viršininkas gen. št. plk. ltn. Antanas Šova konstatavo, kad „karo mokslo silpnoji pusė yra ta, kad jo sudarytos karo teorijos gali būti patikrintos tik karo metu"119, taigi kai jau būna per vèlu, o klaidingos teorijos pasirinkimas ir taikymas gali baigtis karine katastrofa. 1939 m. buvęs karo lakūnas instruktorius, gen. št. plk. ltn. Juozas Jankauskas, 1938-1940 m. Karo mokykloje dèstęs karo istoriją ir aviaciją, rašè: „Jei ịvairūs nauji išradimai kitose mokslo šakose bandomi ir tiriami laboratorijose bei mokslo kabinetuose, tai to, deja, negali atlikti karo mokslas, jo laboratorija - kautynių laukas.“120

Pastaroji citata atskleidžia, kad karo istorijos tyrimai laikytini karybos laboratorija ir tai tarpukariu Lietuvos kariuomenès aiškiai įvardyta. Basilio Henrio Liddellio Harto teigimu, karo istorijos tyrimai padeda rasti naują ir teisingą doktriną, be to, formuoti karių požiūrị ị karybą. Pagaliau, pasak autoriaus, net pats intensyviausias karinis parengimas taikos metu yra labiau teorinis negu praktinis ${ }^{121}$. Analogiškos pozicijos laikèsi ir C. von Clausewitzas - kad karyboje „istoriniai pavyzdžiai viską daro aiškų, be to, yra geriausias ịrodymas praktiniame moksle, o daugiau nei bet kur kitur tai matyti karo mene“. Taip pat, remdamasis Prūsijos gen. Gerhardu Johannu Davidu von Scharnhorstu, rašé, jog „karo reikalų supratimui didžiausią reikšmę turi istoriniai pavyzdžiai““122. A. H. Jomini savo veikaluose gausiai rèmèsi istoriniais pavyzdžiais teigdamas, kad karo istorijoje yra pavyzdžių visiems karinių veiksmų atvejams iliustruoti ir kad istorija - geriausia mokykla. Jo teigimu, kad valstybé būtų deramai pasirengusi gynybai, Generalinis štabas taikos metu turi planuoti karinius veiksmus, o jo archyve turi būti saugomos išsamios karo istorijos statistikos, geografijos, topografijos ir strategijos veikalų analizès ${ }^{123}$.

118 Zaskevičius. Kariuomenès organizacijos ir aprūpinimo pagrindai divizijos ribose. Vadovybės organizacija. 1935 m. LCVA, f. 929, ap. 6, b. 410, p. 5.

119 Šova, A. Kariškos sensacijos ir patyrimai. Trimitas, 1937, balandžio 15, Nr. 15 (832), p. 337.

${ }^{120}$ Jankauskas, [J.]. Tankai ir prieštankiniai ginklai Ispanijos kare. Kardas, 1939, sausio 1, Nr. 1 (303), p. 8.

121 Лиддел Гарт, Б. Стратегия непрямых действий. Москва, 2012, с. 21-26.

${ }^{122}$ Clausewitz, von. C. Apie kara. I dalis. Vilnius, 2008, p. 123.

123 Жомини, Г. Стратегия и тактика в военном искусстве. Москва, 2009, с. 14, 48, 
Puikus pavyzdys - Žiemos karo metu Suomijoje, kai plk. Paavo Juho Talvela dar taikos metais Karo koledže apgynė baigiamąji darbą (suom. Offensiiviset mahdollisuudet Laatokan Karjalassa) apie eventualius karo veiksmus Ladogos Karelijoje, kur ir buvo Tolvajervio sektorius. 1939 m. gruodị su keliais suomių batalionais pulkininkas sumušè dvi sovietų divizijas - 139-ąją ir 75-ąją - ir paėmė daug karo belaisvių ir trofejjų ${ }^{124}$. Taigi karininkas prieš penkiolika metų jau buvo išanalizavęs vietovę ir galimybes joje veikti karo atveju.

A. H. Jomini apibendrino: „Karinès teorijos, pagrịstos teisingais principais, išlaikiusiais tikro karo išbandymus ir papildytais tiksliai užfiksuota karo istorijos patirtimi, taps tikru vadovèliu generolams. Jeigu šie metodai ir nepagimdys didžių žmonių, tai bent išugdys meistriškus generolus, kurie stos į vieną eilę su apsigimusiais karo meno meistrais." ${ }^{25}$ Taigi, anot šio XIX a. autoriaus, karo vadų lavinimo pagrindas - karybos teorijų ir karo istorijos analizè.

Nors, žinoma, lemiamą ịtaką turi istorinio tyrimo pobūdis, kritinio metodo ir objektyvumo aspektai, nes, pasak XVIII a. karo vado Moritzo von Sachseno, tikèti istorikų pasakojimais negalima, nes jie apie karą rašo remdamiesi vaizduote ${ }^{126}$, bet tai XVIII a. pradžios teiginys, kol dar nebuvo šiuolaikinio istorijos mokslo (su visu tyrimų metodologiniu instrumentariumu). Šis „priekaištas“ gali būti paremtas prielaidomis, kad dalis istorikų neturi karybos patirties ir tik bando įsivaizduoti karą, arba subjektyvumu, būdingu ir karo vadams, kurie, kaip ir kritikos autorius, imasi rašytine forma analizuoti karo fenomeną, jo vedimo būdus. Tai suponuoja prielaidą, kad taktikos ir operacijų karo istorijos analizès - tai pirmiausia karininkų, turinčių istoriko išsilavinimą, veiklos sritis. Tačiau dèl to kyla ir santykio su tyrimo objektu problema, nes karininkams gali būti sunku kritiškai vertinti kariuomenę atliekant karo istorijos tyrimus. Visada balansuojama tarp karinių procesų geresnio supratimo (ypač ope-

72, 168, 175, 177, 192, 210, 214, 220, 226, 237, 261, 286, 328.

${ }^{124}$ Engle, E.; Paananen, L. Žiemos karas. Sovietu Sajunga puola Suomija 1939-1940. Kaunas, 2010, p. 105; Petrauskas, R. Trečiojo Reicho triumfas. Antrasis pasaulinis karas Europoje. Pirma knyga. Vilnius, 2010, p. 394-395.

125 Жомини, Г. Стратегия и тактика в военном искусстве. Москва, 2009, с. 341.

${ }^{126}$ Мориц Саксонский. Теория военного искусства. Москва, 2009, с. 26. 
racijų ir taktikos srityse) ir pavojaus diskredituoti sistemą ${ }^{127}$.

1934 m. spaudoje pažymèta, kad karininkams būtina lankyti kautynių vietas, kurių Lietuvoje gausu, ir taip plèsti savo karo istorijos žinias $^{128}$. $1935 \mathrm{~m}$. ypatingụjų reikalų karininkas prie Vyriausiojo štabo gen. št. plk. ltn. Kazys Grinius, išanalizavęs karo istorijos pavyzdžius nuo Napoleono iki Didžiojo karo laikų, aptaręs a priori ir a posteriori doktrinas ${ }^{129}$ bei remdamasis vokiečių karybos teoretikais, padarè išvadą, kad reguliarioji kariuomenè turi būti nedidelè, motyvuota ir mobili, t. y. motorizuota $^{130}$. Remiantis karo istorijos pavyzdžiais Mūsų žinyne analizuota taktika ${ }^{131} .1935 \mathrm{~m}$. generalinio štabo karininkų kursuose studijuojant karo istoriją buvo analizuojama Frydricho II kampanija Silezijoje ir Napoleono - Italijoje, sprendžiamas karo istorijos uždavinys ${ }^{132}$. Karo istorija teikè daug kariuomenès veikimo pavyzdžių ${ }^{133} .1940$ m. Kariuomenès štabas, duodamas nurodymus dèl nemobilizuojamų šaulių panaudojimo, jų uždavinius taip pat formulavo remdamasis istorine patirtimi ${ }^{134}$.

Laikytasi nuomonès, kad karinę propagandą ${ }^{135}$ geriausia diegti per karo istoriją, tačiau Lietuvos kariuomenès pulkai mažai turẻjo savo išleistų istorijų, o ir tos ${ }^{136}$ buvo parašytos taip „negyvai, kad jomis mažai

\footnotetext{
${ }^{127}$ Pavyzdžiui, Pirmojo pasaulinio karo istorijos tyrimai Vokietijoje buvo atliekami jos karininkų tarpukariu. Plačiau žr.: Ланник, Л. В. Победоносные проигравшие: Германская военная элита в 1914-1921 г2. Санкт-Петербург, 2016, с. 10-47.

${ }^{128}$ J. Pažinkime savąji kraštą. Kardas, 1934, rugpjūčio 15, Nr. 16 (193), p. 317.

${ }^{129}$ A priori doktrina - XX a. karo aplinkoje vadas neịstengia valdyti mūšio, todèl priverstas sprendimus priimti $a$ priori, o ir pagal moderniąją strategiją reikia kuo daugiau pajègu ịtraukti ị mūšị ; kita doktrina - a posteriori, t. y. veikimas reaguojant ị ịvykių eigą. Pastarojo principo mūšio metu, turèdamas menkesnes pajègas ir rezervą, laikėsi Napoleonas.

${ }^{130}$ Grinius. Krašto gynimo reikalu. Vairas, 1935, vasaris, Nr. 2, p. 190-201.

${ }^{131}$ Karvelis. Taktika istorijos pavyzdžiuose. Mūsǔ žinynas, 1935, t. XXVIII, Nr. 119, p. 97-108.

132 Bulvičius, V. Generalinio štabo kursai. Kardas, 1935, gegužès 15, Nr. 10 (215), p. 222.

133 Žukas, P. Veiksmai priešo užnugaryje. Trimitas, 1940, birželio 13, Nr. 24 (1017), p. 585.

134 Šaulių panaudojimo reikalu, 1940 m. LCVA, f. 929, ap. 3, b. 1097, 1. 9.

${ }^{135}$ Karinès propagandos tikslas buvo ugdyti tautos ir valstybès karingumą ir pasiaukojimą ginant Tèvynę.

${ }^{136}$ Iki 1940 m. spèta išleisti kelias knygas: 5 péstininkų Didžiojo Lietuvos kunigaikščio Kęstučio pulkas 1919-1934. Kaunas, 1934; 8-tas péstininku Kauno kunigaikščio Vaidoto pulkas 1919-1934. Pulko penkiolikos gyvavimo metu sukakčiai paminèti. Sud. E. Bliudnikas;
} 
domisi ne tik kareiviai, bet ir visuomenë“137. 1935 m. kpt. Stepas Žukaitis parašè 4-ojo pėstininkų pulko istoriją, tačiau Kariuomenès štabo Spaudos ir švietimo skyrius įvardijo nemažai teksto trūkumų ir jo leidybai nepritare $\dot{1}^{138}$. Kaip sektinas pavyzdys rašantiems Lietuvos kariuomenès dalinių istorijas buvo teikiamas Vokietijos kariuomenès [Prūsijos generalfeldmaršalo Ludwigo Leopoldo Gottliebo Hermanno] von Boyeno 5-asis Rytų Prūsijos ${ }^{139}$ pèstininkų pulkas ${ }^{140}$. Šis Vokietijos kariuomenès dalinys pasirinktas, matyt, neatsitiktinai, nes vienas jo batalionas iki Pirmojo pasaulinio karo buvo dislokuotas Klaipėdoje. Pažymėtina, kad Latvijoje pulkų istorijos pradètos leisti anksčiau nei Lietuvoje ir išleistos $7^{141}$, Lietuvoje - 3 péstininkų pulkų ir 1 kavalerijos pulko, be to, būta leidinių, skirtų Karo mokyklos, karo technikos dalinių ir Šaulių sąungos istorijai.

1936 m. Mūsu žinyne rašoma: „Istoriniai darbai yra patys naudingiausi ir jų studijavimas, rodos, turètų sudaryti karininko išsimokslinimo viršūnę. Bet esminè sąlyga, kad taip būtų, jie turi būti rašomi su didžiausiu sąžiningumu, jie turi vaizduoti kautynes su mažiausiomis detalèmis taip

P. Nazaras. Šiauliai, 1934; Gusaras: 1-ojo gusaru Didžiojo Lietuvos etmono Jonušo Radvilos pulko 15 m. gyvavimo sukakčiai paminèti. Red. N. Gasènas. Kaunas, 1934; Bilevičius, [P.] 11 pestininku Vilniaus pulkas. Kaunas, 1939; Matusas, J. Šauliu sajungos istorija. Kaunas, 1939; Karo technikos daliu dvidešimtmetis 1919-1939. Kaunas, 1939; Pirmojo Lietuvos Prezidento karo mokykla, 1919-1939. Kaunas, 1939; Dalinių istorijos buvo publikuojamos ir karineje periodikoje.

${ }^{137}$ Delininkaitis. Kariškoji propaganda. Kardas, 1935, rugsèjo 15, Nr. 18 (223), p. 385.

138 4-ojo pesstininkų pulko $1935 \mathrm{~m}$. lapkričio 9 d. vado raštas. $L C V A$, f. 929 , ap. 6, b. 240,1 . 2; Spaudos ir švietimo skyriaus 1935 m. gegužès 10 d. raštas. $L C V A$, f. 929, ap. 6, b. 240, 1 . 5.

${ }^{139} 1910$ m. Berlyne išleistoje 41-ojo von Boyeno (5-ojo Rytų Prūsijos) pèstininkų pulko istorijoje aprašoma, kaip pulkas buvo suformuotas, paskui - jo karinè patirtis, išskirtinị dèmesị skiriant $1866 \mathrm{~m}$. ir 1870-1871 m. karinèms kampanijoms, toliau pereinama prie pulko istorijos taikos metu ir pateikiama informacija apie pulko šefus ir vadovybę: Schimrigk, W. Das Infanterie-Regiment von Boyen (5. Ostpreußisches) Nr. 41. Berlin, 1910. ${ }^{140}$ Delininkaitis. Kariškoji propaganda. Kardas, 1935, rugsèjo 15, Nr. 18 (223), p. 385.

${ }^{141} 1$ 1. Liepājās kājnieku pulka tapšanas un pārbaudīšanas gadi (1919.-1922.). Rīga, 1926; 2. Ventspils kājnieku pulks. Liepāja, 1936; 3. Jelgavas kājnieku pulks. Jelgava, 1929; 6. Rīgas kājnieku pulka vēsture 1919-1929. Rīga, 1929; 8. Dauvgavpils kājnieku pulka vēsture. Cēsis, 1930; 9. Rēzeknes kājnieku pulka gaitas. Rīga, 1923; Vidzemes artilērijas pulka vèsture. Rīga, 1938. 
tiksliai, kaip tat yra galima žmogui. “142

1938 m. Karde, buvo perspausdinti Vokietijos autorių samprotavimai apie karo istorijos svarbą karybai:

„Karo istorijos mokslo svarbus tikslas turi būti žmogaus dvasios griežtas formavimas, fantazijos tyrimas, militarinès vaizduotès galių ugdymas. Karo istorijos mokslo niekintojai visada tai atmeta sakydami, kad tuo būdu norima surasti šiokių tokių patentų, pagal kuriuos vadovybẻ darytų savo sprendimus. Nieko nèra išvirkštesnio, nieko kvailesnio, kaip tas. Nè vienas tikras karo istorijos mokslininkas apie tokią kvailybę negalvoja. I karo istorijos mokslą, kariškai kalbant, galima žiūrèti kaip ị dvasinị derlių, kaip ị dvasinị smegenų kelių išaštrinimą, kad galètų suprasti militarinius pasiryžimus. <...> Tiktai rimtos karo istorijos studijos leidžia protui subręsti lemiamiems sprendimams. Pasąmoneje jų dèka susikaupia didelès jègos, kurios dideliems vadams, kurie karo istorijos mokslui skyrè didelès reikšmès, tam tikra prasme leidžia daryti divinatorinius [intuityvius] sprendimus. Studijos pažadina fantaziją, paaštrina ịsivaizdavimo galias. Todèl jos dèka, turint didesnị karo istorijos mokslo pažinimą, galima daug greičiau, tiksliau ir sąmoningiau padètị ịvertinti. “143

Teigta, kad atsargos karininkai, studijuodami istorinių kautynių pavyzdžius ir skaičiuodami techninių kovos priemonių poreikị mūšyje, tobulins savo teorines karybos žinias ${ }^{144}$. Bet tai nereiškia, kad teorinès studijos, net ir turintiems praktinès karo patirties, gali atskleisti tikrajj karo veidą, nes Pirmojo pasaulinio karo patirtis, pasak J. N. Cru (kuris buvo šio karo veteranas, kovojęs Prancūzijos kariuomenès gretose), atskleidè, kad iki 1914 m. karo neišgyvenusi karta iš esmès nieko apie ji nežino, nors mane žinanti iš knygų karo istorijos temomis, tačiau tas „žinojimas“ buvo klaidingas ir idealizuotas ${ }^{145}$. Kita vertus, tai nepaneigia karo istorijos reikšmès karybos teorijai, nors ir nepadeda kovotojui psichologiškai

\footnotetext{
${ }^{142}$ Grasset, plk. Kaip rašyti kautynių monografiją. Comment mèttre sur pied la monographie de combat (iš prancūzų kalbos vertė kpt. Šalkauskas). Mūsų žinynas, 1936, t. XXX, Nr. 134, p. 464.

${ }^{143}$ Gustainis, V. Specialybès ir bendroji kultūra. Kardas, 1938, sausio 1, Nr. 1 (279), p. 12. ${ }^{144}$ Gai-tis, J. Atsargos karininkų paruošimas. Kardas, 1936, lapkričio 15, Nr. 22 (251), p. 593.

${ }^{145}$ Головин, Н. Н. Наука о войне. Избранные сочинения. Москва, 2008, с. 46-48.
} 
pasiruošti karo meto patirtims ir išgyvenimams.

Tarpukariu teigta, kad nuoseklus domejjimasis karo istorija ir kitos priemonès turi didelę reikšmę atsargos karininkų kompetencijai ${ }^{146}$. 1939 m. buvo tikinama, kad „karo istorija yra neišsemiamas šaltinis nors ir pačio mažiausio dalinio mokymui, auklejjimui ir taktiniam parengimui“. Kartu atkreiptas dèmesys ị tai, kad, „deja, daugelio karo patyrimo neturinčių karininkų karo istorijos žinios yra labai kuklios ${ }^{{ }^{\prime 147}}$. Nors karo istorija dėstyta Karo mokykloje ir ịvairiuose kursuose ${ }^{148}, 1921 \mathrm{~m}$. tai buvo pavesta mjr. Vaclovui Biržiškai ${ }^{149}$. Karo istorijai buvo skirta 20 val. paskaitų, dèstyta pradedant senovès graikų ir Aleksandro Makedoniečio žygiais, Romos imperijos karais, kryžiaus žygiais ir t. t., pereinant prie Lietuvos karo istorijos temų, kurios apėmė LDK karo istoriją ir $1812 \mathrm{~m}$. Napoleono žygi per Lietuvą, XIX a. sukilimus ${ }^{150}$. Tuo metu V. Biržiška aktyviai raše karo istorijos temomis ir buvo pradejęs rengti knygą Lietuvos karo istorijos bruožai ${ }^{151}$. Karo istorija taip pat buvo dèstoma Karo aviacijos puskarininkių mokykloje $\mathrm{e}^{152}$, pradinių mokyklų mokytojų kursuose ${ }^{153}$. Aukštuosiuose kūno kultūros kursuose greta kitų karinių disciplinų buvo dèstoma ir karo istorija ${ }^{154}$. Domètasi karo istorijos dèstymu Sovietų Rusi-

\footnotetext{
${ }^{146}$ Binkis-Binkevičius. Atsargos karininkų karinio pasirengimo lygis. Kardas, 1938, lapkritis, Nr. 22 (300), p. 518.

147 Z. R. Karo istorijos reikšmè dalinio mokymui. Kardas, 1939, rugpjūčio 15, Nr. 16 (318), p. 400.

${ }^{148}$ Plačiau žr.: Ažubalis, A. et al. Karo pedagogika Lietuvoje (1918-1940 m.). Vilnius, 2007.

${ }^{149}$ Karo mokyklos viršininko 1921 m. rugpjūčio 2 d. LCVA, f. 929, ap. 6, b. 31, 1. 22.

${ }^{150}$ Programa karų istorijos pamokų [1921 m.]. LCVA, f. 929, ap. 6, b. 31, 1. 34.

151 Žukas, V. Gyvenimas knygai: Vaclovas Biržiška. Vilnius, 2012, p. 122.

152 Kelio akmenèlis. İsteigta puskarininkių lakūnų mokykla. Karys, 1929, sausio 24, Nr. 3 (503), p. 49.

${ }^{153}$ Balčiūnas. Nauji mūsų talkininkai. Karys, 1929, rugpjūčio 22, Nr. 33 (533), p. 551. Plačiau apie karinị rengimą švietimo ir mokslo ịstaigose žr.: Ažubalis, A.; Kazlauskaitè-Markelienè, R.; Žilènienè, V. Karinis rengimas Lietuvos mokykloje (19291940 m.). Vilnius, 2009.

${ }^{154}$ Pirmieji egzaminai. Karys, 1935, sausio 24, Nr. 4 (827), p. 93; Jašinskas, J. Aukštieji kūno kultūros kursai. Kardas, 1936, birželio 15, Nr. 12 (241), p. 336.
} 
joje $^{155}$, Čekoslovakijoje ${ }^{156}$, Belgijoje ${ }^{157}$, Latvijoje $\mathrm{e}^{158}$, Lenkijoje ${ }^{159}$, Italijoje $\mathrm{e}^{160}$ ir kitose šalyse. Tarpukariu karo istoriją dèstè būsimi generolai plk. ltn. Jonas Juodišius (1930-1934 m.) $)^{161}$, gen. št. plk. Kazys Tallat-Kelpša ${ }^{162}$, gen. št. plk. ltn. Juozas Jankauskas (1938-1940 m.) ${ }^{163}$, gen. št. plk. Povilas Žilys ${ }^{164}$, mjr· Kazys Sabalys ${ }^{165}$ ir kiti. Šią discipliną dèstè ir 1932 m. Karo istorijos ivvado konspekta parengè gen. ltn. Zenonas Gerulaitis ${ }^{166}$, o 1933 m. gen. št. plk. ltn. S. Raštikis parengè Karo istorijos konspekto I dali ${ }^{167}$, nes, jo teigimu, gavo ịsakymą Karo mokykloje skaityti karo istorijos, įtraukiant ir Lietuvos karo istoriją, paskaitas, o vadovèlių nebuvo, todèl kiekvienai paskaitai rašè konspektą. Jų pagrindu su daugybe schemų vèliau buvo parengtas ir išleistas atskiras leidinys ${ }^{168}$. Antrą konspektų dalị 1936 m. parengė gen. št. plk. S. Zaskevičius ${ }^{169}$. Visi trys 100 egz. tiražu rotaprintu ${ }^{170}$ atspausdinti leidiniai buvo skirti karininkų rengimui.

${ }^{155}$ Karo chronika: Rusijoj. Karys, 1923, rugsejo 20-26, Nr. 38 (226), p. 427.

156 Čekoslovakijos karo mokslo įstaigų ir fizinio lavinimosi apžvalga. Karys, 1923, balandžio 26-gegužès 2, Nr. 17 (205), p. 204.

157 Tallat-Kelpša, K. Belgija: Karo akademija (Ecole de guerre). Karys, 1922, gegužès 11, Nr. 19 (155), p. 226.

158 Aukštųjų karo mokslo kursų klausimas Latvijoje. Karys, 1921, spalio 6, Nr. 40 (124), p. 466.

${ }^{159}$ Lenkų karo inžinerijos mokykla. Karys, 1925, spalio 15-21, Nr. 42 (334), p. 342.

${ }^{160}$ Kariškos žinios: italų studentijos militarizavimas. Karys, 1931, liepos 2, Nr. 27 (631), p. 545 .

${ }^{161}$ Asevičius, V. et al. Lietuvos kariuomenès karininkai 1918-1953, t. IV. Vilnius, 2004, p. 99.

162 Asevičius, V. et al. Lietuvos kariuomenès karininkai 1918-1953, t. VIII. Vilnius, 2008, p. 16.

${ }^{163}$ Asevičius, V. et al. Lietuvos kariuomenès karininkai 1918-1953, t. IV. Vilnius, 2004, p. 42 .

164 Asevičius, V. et al. Lietuvos kariuomenès karininkai 1918-1953, t. VIII. Vilnius, 2008, p. 353.

165 Asevičius, V. et al. Lietuvos kariuomenes karininkai 1918-1953, t. VII. Vilnius, 2007, p. 15.

${ }^{166}$ Gerulaitis, Z. Karo istorijos ivvadas. Kaunas, 1932.

${ }^{167}$ Raštikis, S. Karo istorijos konspektas. I dalis. Kaunas, 1933.

${ }^{168}$ Raštikis, S. Kovose del Lietuvos. I. t. Vilnius, 1990, p. 277.

169 Zaskevičius, S. Karo istorijos konspektas. II dalis. Kaunas, 1936.

${ }^{170}$ Rotaprintas [lot. rota - ratas + angl. print - spausdinti] - supaprastinta spausdinimo 
1939 m. brg. gen. J. Juodišius Karo mokyklos baigimo proga naujiesiems karininkams priminė nuolatinio profesinio tobulejjimo svarbą ir pabrèžè, kad pirmoje vietoje turètų būti karo istorija, divizijų ir pulkų veiksmų aprašymai ir atsiminimai ${ }^{171}$.

Karininkams, norintiems studijuoti užsienio aukštosiose karo mokyklose, buvo būtina išlaikyti karo istorijos egzaminą ${ }^{172} .1930 \mathrm{~m}$. sausio 27-30 d. kandidatai vykti ị užsienio karo akademijas laikė kalbų, karo istorijos, bendrosios ir Lietuvos istorijos, taktikos, taikomosios taktikos, geografijos ir topografijos egzaminus ${ }^{173}$. Karininkai, pretenduojantys studijuoti Lietuvoje Generalinio štabo kursuose, turejo laikyti stojamuosius egzaminus. $1932 \mathrm{~m}$. kandidatai studijuoti šiuose kursuose laike 7 egzaminus: a) taktikos; b) karo istorijos; c) visuotinès istorijos; d) geografijos; e) topografijos ir f) dviejų užsienio kalbų (pasirinktinai - prancūzų, vokiečių, rusų ar lenkų) ${ }^{174}$. Buvo parengtos atskiros karo istorijos ${ }^{175}$ ir visuotinès istorijos ${ }^{176}$ egzaminų programos. $1933 \mathrm{~m}$. karo istorijos egzaminuotojai buvo gen. ltn. Z. Gerulaitis ir gen. št. plk. Stasys Pundzevičius, o visuotinès istorijos - gen. št. plk. J. Lanskoronskis. Karininkai, be dvieju istorijos egzaminų, laikẻ bendrosios taktikos, péstininkų taktikos, geografijos, topografijos ir užsienio kalbos egzaminus ${ }^{177} .1938 \mathrm{~m}$. pretendentų eiti bataliono ir kuopos vado pareigas egzaminų sąrašas buvo papildytas karo istorijos egzaminu ${ }^{178}$. Laikant egzaminus buvo būtina žinoti ne tik karo istorijos faktus, bet ir išmanyti bendrą istorinị kontekstą, nes

\footnotetext{
mašina, veikianti ofseto principu.

${ }^{171}$ Gilios prasmės žodžiai jauniesiems. Kardas, 1939, spalio 1, Nr. 19 (321), p. 471.

${ }^{172}$ Vyriausiasis štabas, 1925 m. gegužès 9 d. LCVA, f. 929, ap. 6, b. 75, 1. 260-276.

${ }^{173}$ Pateikiamas istorijos egzamino karininkams temų sąrašas: programa, pagal kurią buvo egzaminuojami karininkai, siunčiami it užsienio karo akademijas. Kardas, 1930, kovas, Nr. 3 (11), p. 47.

${ }^{174}$ Vyriausiojo štabo aplinkraštis, 1932 m. lapkričio 16 d. LCVA, f. 515, ap. 1, b. 14, 1. 222. ${ }^{175}$ Istojamųjų egzaminų ì generalinio štabo kursų II laidą Karo istorijos programa, 1933 m. LCVA, f. 384, ap. 5, b. 24, 1. 12.

176 Istojamųjų egzaminų ị generalinio štabo kursų II laidą Visuotinès istorijos programa, 1933 m. LCVA, f. 384, ap. 5, b. 24, 1. 13.

177 Vyriausiojo štabo 1933 m. vasario 20 d. aplinkraštis. LCVA, f. 384, ap. 5, b. 24, apv. 1. 9. ${ }^{178}$ Naujos programos karininkų egzaminams. Kardas, 1938, birželio 15, Nr. 12 (290), p. 297.
} 
tai buvo fonas, kuriame „ryškiau iškyla nagrinejjamo mūšio, kampanijos

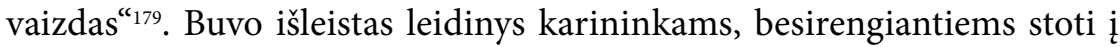
Vytauto Didžiojo aukštąją karo mokyklą, turejjusią ne tik aukštojo mokslo žinias karininkams perteikti, bet „kurti ir tobulinti karo mokslą ir jo duomenis taikyti mūsų krašto [Lietuvos - V. J.] sąlygoms ir reikalams “ ${ }^{\text {“180, }}$, kuriame karo istorijai skirtas net atskiras skyrius, nurodyta, ką ir kokiame kontekste turi žinoti kandidatai. Stojančiųjų karo istorijos programa apėmè tik „pavyzdines operacijas ar kautynes, ypač susijusias su veiksmais istorineje ir etnografineje Lietuvoje ${ }^{\text {"181 }}$. Taigi buvo aktualizuojama tos pačios erdvès, kurioje eventualiai turëjo veikti ir būsimieji generalinio štabo karininkai, reikšmè, pažymint, kad kiekvienas kandidatas turi gebėti iš karo istorijos atvejų analizès padaryti „mūsų laikams reikšmingas išvadas“. Taigi išryškinta karo istorijos žinių pritaikomumo svarba.

Lietuvos kariuomenès štabas laikèsi pozicijos, kad „kariuomenė yra tautiško ir valstybinio auklejjimo mokykla“182 ir „šiandien [1939 m. - V. J.] labiau negu bet kada svarbu turèti kareivius ne tik kariškai gerai apmokytus, bet ir gerai pilietiškai išauklètus, neužguitus, politiškai sąmoningus" ${ }^{\text {"183 }}$. Istorija buvo įtraukta ị kareivių mokymo programas ${ }^{184}$, jos buvo mokoma kariniuose daliniuose $\mathrm{e}^{185} .1934 \mathrm{~m}$. lapkričio $13 \mathrm{~d}$. Z. Ivinskis tankų kuopos kariams perskaitė paskaitą Lietuvos kariuomenés istorija, kurioje pirmiausia apžvelgè lietuvių tautinių dalinių kūrimosi Rusijoje ypatumus, o vèliau kariuomenès kūrimo darbą Lietuvoje ${ }^{186} .1940$ m. kariams išleis-

\footnotetext{
${ }^{179}$ Karo mokslo skyrius [be datos]. LCVA, f. 929, ap. 6, b. 406, [lapai nenumeruoti, psl. 27].

${ }^{180}$ Vytauto Didžiojo Aukštosios Karo Mokyklos įstatymas. Vyriausybès žinios, 1938, gruodžio 10, Nr. 627, p. 1.

${ }^{181}$ Nurodymai, kaip rengtis ị Vytauto Didžiojo aukštają karo mokyklą, ir antruju konkursinių egzaminu programos. Trečias pataisytas leidimas. Kaunas, 1940, p. 33. [LCVA, f. 929, ap. 6, b. 407].

${ }^{182}$ Kariuomenès štabo 1935 m. spalio 9 d. aplinkraštis. $L C V A$, f. 929 , ap. 1, b. 591, 1. 33.

${ }^{183}$ Kariuomenès štabo 1939 m. gruodžio 22 d. aplinkraštis. $L C V A$, f. 929, ap. 1, b. 639, 1. 4.

${ }^{184}$ Kareivių švietimo programa, 1926 m. liepos 14 d. LCVA, f. 929, ap. 6, 1. 57.

${ }^{185}$ Dykūnas, S. 4 pèst. L. K. Mindaugo pulkas. Karys, 1931, kovo 5, Nr. 10 (614), p. 202; V. J. J. 1 pèst. D. L. K. Gedimino pulkas. Karys. 1931 sausio 29, Nr. 5 (609), p. 91; R. St. 5 pèst. D. L. K. Kęstučio pulkas. Karys. 1932, lapkričio 2, Nr. 45 (701), p. 896.

${ }^{186}$ Ivinskis, Z. [Lietuvos kariuomenès istorija]: Paskaitos, skaitytos tankų kuopai, apmatai.
} 
tuose vadovèliuose daug dèmesio skirta istorijai, politikai, geografijai ir kitiems mokslams ${ }^{187}$, taip siekta pakelti $\mathfrak{i}$ aukštesnị lygi arba bent suvienodinti patriotinị karių švietimą. Pagrindinis leidinyje išdèstyto paskaitų ciklo tikslas buvo „suformuoti kareivio ideologiją“. Fantasmagoriškai, atsižvelgiant $\mathfrak{j}$ tai, kad iki sovietinès okupacijos buvo likę tik keli mėnesiai, skamba instrukcijos autoriams tekstas: „Šio leidinio reikšmè turès būti žymiai didesnè negu kurio kito leidinio. Normaliai išleista knyga perskaitoma vieną kartą ir dažniausiai padedama ị šalị. Šio gi leidinio mintys kasmet iš naujo bus gyvu žodžiu skelbiamos kareiviams, šauliams ir plačiajai visuomenei. “188 Lūkesčiai neišsipildè, knyga nugrimzdo užmarštin, nors 1940 m. kovo 9 d. Kariuomenès štabas paprašè Spindulio spaustuvès skubiai atspausdinti šio leidinio 3000 egz. ${ }^{189}$ Išleisti spèta, šių knygų galima rasti Lietuvos bibliotekose.

Kareivių švietimo programoje pabrež̌ta, kad „istorija turi supažindinti kareivius su Lietuvos valstybès ir lietuvių tautos praeitimi, sukelti ryžimąsi sekti savo protèvių pėdomis. Todèl mokant istorijos ypatingai turi būti pabrěžiami lietuvių tautos ir atskirų jos asmenų karžygiškumo pavyzdžiai“, o karių švietimas ịvardytas kaip dar viena priemonė, padedanti „parengti kareivị karui“"190. Konstatuojant, kad karo istorija labai platus mokslas, pabrèžta, kad jaunimą ir karius pirmiausia reikia supažindinti su Pirmuoju pasauliniu ir Nepriklausomybès karais, daugiau dèmesio skiriant pastarajam, nes „nieko negali būti gražesnio ir auklejjančio kaip partizanų būrio veikimas. Kiek čia pasiaukojimo, ištvermès ir meilès tèvynei. Niekas tiek neịkvèps meilès tėvynei, kaip tinkamas pirmųjų karių, už tèvynę žuvusių, apibūdinimas. Ir niekas tiek neįkvepia drąsos, kaip laimèti mūsų kariuomenès mūšiai ties Giedraičiais, Širvintomis ir kitur “"191.

Plk. ltn. Kazys Abaravičius Karo pedagogikos konspekte rašè, kad ko-

1934 m. lapkričio 13 d. Lietuvos nacionalinès M. Mažvydo bibliotekos Rankraščių fondas, f. 29-866, 1. 1-9.

${ }^{187}$ Karinio auklejimo paskaitos. I-II knyga. Kaunas, 1940.

${ }^{188}$ Nurodymai leidinio „Paskaitos kareiviams“ bendradarbiams. LCVA, f. 929, ap. 5, b. $361,1.6-7$ apv. 1 .

1891940 m. kovo 9 d. raštas „Spindulio“ spaustuvei. LCVA, f. 929, ap. 5, b. 361, 1. 23.

${ }^{190}$ Kareivių švietimo programa, 1939 m. balandžio 22 d. LCVA, f. 929, ap. 6, b. 235, 1. 905.

${ }^{191}$ Karinio rengimo metodika [be datos]. LCVA, f. 929, ap. 6, b. 402, 1 [nenumeruota, paskutinis]. 
votojas turi gebėti pasiaukoti kitų, tautos, labui, įveikti mirties baimę, t. y. nugalèti igimtą išlikimo instinktą, ir tik „Dvasios milžinai“ galès kovoti ateities kare, kuriame kovos ne tik kariuomenè, bet ir visa tauta ${ }^{192}$. Taigi karių motyvacijai stiprinti pasitelkta karo istorija, kuriamas ne tik apskritai kario, bet ir konkrečiai partizano - garbingo Tẻvynès gynejjo - ịvaizdis.

1935 m. VDU studentų korporacijos Ramovè, kuri vienijo studentus atsargos karininkus, nariai deklaravo, jog „bus ieškoma kelių, kad aukštosiose mokyklose (universitete ir kitur) būtų įvesta karo istorija, karo geografija arba bendrai karo mokslo katedra, kurios klausymas ir pratybos darbai būtų privalomi kiekvienam studentui“'193. $1936 \mathrm{~m}$. studentų korporacijos Ramove parengtam karinès propagandos spaudoje planui pritarė ir Kariuomenès štabas. Plane buvo numatyta rašyti apie mažų kariuomenių kovų istoriją, „senovės lietuvių“ kovas, Nepriklausomybės karus ir kitomis karo istorijos temomis ${ }^{194} .1937 \mathrm{~m}$. VDU pritare idejjai universitete déstyti Krašto gynimo ir apsaugos kursq - apie tai rugsejo 15 d. jo rektorius prof. Mykolas Romeris paskelbè VDU mokslo metų atidarymo iškilmėse ${ }^{195}$, vienas iš mokomųjų dalykų turèjo būti Karo istorijos bendrieji bruožai ${ }^{196}$. Buvo nuspręsta, kad Krašto gynimo ir apsaugos kursas bus privalomas visiems VDU studentams. $1937 \mathrm{~m}$. spalio $28 \mathrm{~d}$. švietimo ministras prof. Juozas Tonkūnas pristatė pakeistą VDU etatų sąrašą, kuriame atsižvelgiant ị KAM pageidavimą buvo numatyti dèstytojų minètam kursui skaityti etatai ${ }^{197}$.

Tai, kad karo istorija, ypač Lietuvos, kariuomenès vadovybės buvo vertinama kaip rimtas pagrindas planuojant šalies ginkluotąją gynybą, liudija 1940 m. Lietuvos kariuomenès štabo dokumentas, kuriame, aptariant šaulių panaudojimo karo atveju galimybes, teigiama, kad šauliai

\footnotetext{
192 Karo pedagogika (konspektas), II pataisyta laida, plk. ltn. [K.] Abaravičius, 1939 m. LCVA, f. 929, ap. 6, b. 403, apv. 1. 3.

${ }^{193}$ Damašius, Kl. Stud. ats. kar. korp. „Ramovès“ kariškoji propaganda. Kardas, 1935, sausio 1, Nr. 1 (202), p. 17.

${ }^{194}$ Kariškos propagandos spaudoje planas, 1936 m. LCVA, f. 384, ap. 5, b. 31, 1. 20-23.

195 V. D. Universitete prasidejo mokslas. Karys, 1937, rugsèjo 23, Nr. 39 (966), p. 1108.

196 Ažubalis, A.; Kazlauskaitè-Markelienè, R.; Žilènienė, V. Karinis rengimas Lietuvos mokykloje (1929-1940 m.). Vilnius, 2009, p. 135-144.

197 Universiteto etatų pakeitimo projektas Seime. Karys, 1937, lapkričio 4, Nr. 45 (972), p. 1299.
} 
galètų kovoti su mechanizuotais priešo junginiais, bet tik savo teritorijoje, palaikomi vietos gyventojų, kai karo veiksmai vyksta plačiu frontu. Taip pat konstatuojama, kad „nei viena Europos didžioji valstybė tokiose sąlygose kovoti nesirengè ir nesirengia, tad nèra ko stebètis, kad ieškant užsienyje nerandama tokių pavyzdžių, kurie tiktų mažai valstybei, besirengiančiai kovoti plačiais frontais savoje teritorijoje. Mažos valstybès dažniausiai aklai seka didelių valstybių pavyzdžius, todèl ir mažos valstybès pavyzdžių nèra ko ieškoti. Reikia kurti be pavyzdžių, paimtų iš šalies, remiantis tik geru savų sąlygų pažinimu“"198. Pastaroji citata atskleidžia didžiųjų valstybių karybos adeptų mažųjų valstybių kariuomenėse problemą, bandant mechaniškai perkelti pirmųjų požiūrị i karą, jų taktiką, operacijų meną ir strategiją, kas dèl ịvairių priežasčių (ribotų mažųju valstybių išteklių, mažos teritorijos ir t. t.) „neperkeliama“ arba lemia neigiamą rezultatą - pralaimèjimą. Todèl mažųjų valstybių kariuomenès turi: 1) analizuoti galimų priešų karybą, kad galètų nustatyti jų silpnybes ir rasti sprendimus, kaip jas išnaudojant organizuoti savo gynybą; 2) nagrinèti potencialių sąjungininkų karybą, kad prireikus būtų įmanoma sąveika; 3) analizuoti savo karinę patirtị, kad nuspręstų, kokie strateginiai, operatyviniai ir taktiniai sprendimai priimtini, gali būti turimų karinių pajėgų igyvendinti ir bus rezultatyvūs; 4) apskritai kaupti medžiagą ir nagrinèti pasaulio karybą, kad matytų savo, priešų ir sąjungininkų karybos kontekstą, suvoktų transformacijų eigą ir tendencijas, kurios padètų nacionalinèms kolektyvinio intelekto grupėms (angl. Think Tank) - „idejuc kalvèms“ - produktyviai veikti. Tai neturètų virsti dviračio išradinèjimu, bet pirmiausia taptu jo tinkamo modelio pasirinkimu (paremtu analize), atsižvelgiant $\mathfrak{i}$ nacionalinius poreikius ir galimybes. Visi keturi punktai svarbūs, bet pirmas ir trečias, t. y. priešo ir savo karybos patirties analizè, yra prioritetiniai. Tačiau bet kuriuo atveju reikia remtis karo istorija, nes bent kiek objektyviau analizuoti galima tik praeities ịvykius ir procesus, kurie yra tyrimo objektai. Dabarti galima subjektyviai aptarti, o ateiti prognozuoti, remiantis istorija.

198 Šaulių panaudojimo reikalu [1940 m.]. LCVA, f. 929, ap. 3, b. 1097, 1. 9-9 apv. 1. 
II.

Darytina prielaida, kad Pirmasis pasaulinis (Didysis) karas buvo stiprus postūmis rinkti karo istorijos medžiagą ir net svarstyti ją aprašyti Lietuvoje. Nors atliekami tyrimai bent iš dalies turètų atskleisti, kaip Lietuvos ir (ar) lietuvių visuomenèje buvo reflektuojami XIX a. ir XX a. pradžios Rusijos imperijos karai (pvz., Krymo, Rusijos-Turkijos ar Rusijos-Japonijos karas ir kiti) ir karo veiksmai Lietuvoje (XIX a. sukilimai), kurie palietè visuomenę, jei ne tiesiogiai, tai bent jau iš Lietuvos paimtiems vyrams atliekant karo tarnybą ${ }^{199}$, taip pat koks buvo požiūris i Didiji karą ${ }^{200}$. 1914-1915 m. lietuviškoje spaudoje aktualizuotas karo istorijos rašymo klausimas, nes „šis karas bus šimtais metų mūsų vaikų ir anūkų", atkreipiant demesị ne tik ì plataus masto karines operacijas, bet ir iqvairias kasdienes smulkmenas, kurios ir padeda susidaryti bendrą ivykių vaizdą ${ }^{201}$. Buvo teikiamos rekomendacijos rašantiems atsiminimus apie Pirmąji pasaulinị karą, pvz., dèl jų struktūros, kad tai padètų ateityje Lietuvos istorijos tyrejjams. Skatinta rinkti skelbimus, atsišaukimus, periodinius leidinius ir t. t., susijusius su karu ir siųsti šią medžiagą Lietuvių mokslo draugijai, kuri ją saugotų ir padarytų visiems prieinamą ${ }^{202}$.

Po Pirmojo pasaulinio ir Nepriklausomybès karų, plètojant karo mokslus, kurių svarbą gana vaizdžiai nusakẻ Karo mokyklos viršininkas gen. ltn. Jonas Galvydis-Bykauskas, - kad „žmogus be tikejjimo ir karo mokslo yra tikras, atsiprašant, kiaule “ ${ }^{203}$, - nuošalyje neliko ir karo istori-

\footnotetext{
${ }^{199}$ Lietuvos mokslo tarybos finansuojamas Valstybinės lituanistinių tyrimų ir sklaidos 2016-2024 m. programos projektas Lietuviškoji karo samprata tarpukaryje (1918-1940), vadovas dr. Deividas Šlekys (Vilniaus universitetas).

${ }^{200}$ Lietuvos mokslo tarybos finansuojamas mokslininkų grupių projektas Pirmojo pasaulinio karo atminimas: Lietuvos ir Rytprūsiu lyginamoji analizé (iki 1939 metu), vadovas dr. Vasilijus Safronovas (Klaipėdos universitetas).

${ }^{201}$ Gk. [Bugailiškis, P.] Rinkime karo meto medžiagą! Lietuvos ūkininkas, 1914, rugsèjo 18 (spalio 1), Nr. 38, p. 350; Papentis [Šmulkštys, A.] Rašykime karo istoriją! Šaltinis, 1915, gegužès 30 (birželio 12), Nr. 21-22, p. 137-138 [už nuorodas ị 1914-1915 m. leidinius autorius dèkoja dr. V. Safronovui].

${ }^{202}$ Plačiau žr.: Gk. [Bugailiškis, P.] Karo istorijos medžiaga. Lietuvos žinios, 1914, lapkričio 1 (14), Nr. 174, p. 1-2.

${ }^{203}$ Plačiau apie generolą ir jo vaizdingus posakius žr.: Jakštys, G. Karo mokyklos viršininkas gen. Jonas Galvydis-Bykauskas. Generolas Jonas Galvydis-Bykauskas 1864-1943.
} 
ja. Visą tarpukarị Lietuvos kariuomenèje veikẻ padalinys, kuris rūpinosi tiek apskritai karo mokslų plètra, tiek konkrečiai karo istorijos tyrimais. 1918 m. spalio mèn. Stasio Šilingo iniciatyva Jonui Martynui Laurinaičiui buvo pavesta sudaryti literatūros komisiją, kuri tvarkytų „karinių raštų leidimą“. Oficialiai komisija darbą pradejjo gruodžio $1 \mathrm{~d} .^{204}$, jos pagrindu ịkurtame Literatūros skyriuje dirbo karininkai Jonas Martynas Laurinaitis, Pranas Tvaronas ir Petras Ruseckas bei kalbininkas Stasys Naginskas, taip pat civiliai tarnautojai Štuopys, Antanaitis ir Banaitis, nes, anot P. Rusecko, „karininkų, „mokančių plunksną valdyti“, kurie galètų pereiti ị skyrių, negalëjo rasti ir gauti“ ${ }^{205} .1921 \mathrm{~m}$. Literatūros skyrius buvo reorganizuotas i Karo mokslo skyrių, o šis 1926 m. - i Karo mokslo valdybą, $1929 \mathrm{~m}$. valdybos pagrindu suformuotas Spaudos ir švietimo skyrius, kuris veikè iki sovietinès okupacijos ${ }^{206}$. Vienas pirmųjų Krašto apsaugos ministerijos Literatūros skyriaus leidinių karo istorijos tema buvo 1920 m. išleista Vytauto Steponaičio knyga apie kovų su Raudonąja armija epizodą ${ }^{207}$ ir 1921 m. pasirodžiusi Augustino Janulaičio knyga apie 1863-1864 m. sukilimą Lietuvoje ${ }^{208} .1923$ m. Karo mokslų skyrius išleido mjr. Aleksandro Ružancovo sudarytą Lietuvos karo bibliografija $q^{209}$. 1918-1926 m. kariuomenè išleido 5 neperiodinius istorijai skirtus leidinius $^{210} .1929$ m. atlikus karininkų apklausą paaiškejjo, kad 26,4 \% atsakiusiụjų i pateiktos anketos klausimus (53 iš 202, iš kurių 18 buvo atsargos, o 35 - aktyviosios tarnybos kariai) spaudoje rašè istorijos temomis ${ }^{211}$, taigi karininkija buvo gana aktyvi.

Eksponatus, daiktus ir medžiagą, kuri būtų „gyvas paveikslas garbin-

\footnotetext{
Ats. red. A. Alonderis, Vilnius, 2014, p. 81.

${ }^{204}$ Lesčius, V. Lietuvos kariuomenè 1918-1920. Vilnius, 1998, p. 103.

${ }^{205}$ Ruseckas, P. Literatūros skyriaus veikla iki 1920. V. 15. Mūsu žinynas, 1938, t. XXXV, Nr. 11-12 (165-166), p. 848.

${ }^{206}$ Jakštas, P. Lietuvos karinè spauda 1918-1938. Mūsų žinynas, 1938, t. XXXV, Nr. 11-12 (165-166), p. 811-812.

${ }^{207}$ Steponaitis, V. Karas su bolševikais: Ežerènu operacija. Kaunas, 1920.

${ }^{208}$ Janulaitis, A. 1863-1864 m. sukilimas Lietuvoje. Kaunas, 1921.

${ }^{209}$ Ružancovas-Ružaniec, A. Lietuvos karo bibliografija 1917-1922 = Bibliographie militaire Lithuanienne 1917-1922. Kaunas, 1923.

${ }^{210}$ Neperiodiniai leidiniai. LCVA, f. 929, ap. 6, b. 84, 1. 572.

${ }^{211}$ Steponaitis, V. Karininkai spaudos darbo srityje. Kaunas, 1931, p. 34.
} 
gos praeities mūsų Tẻvynès“ ir susijusi „su mūsų kova, nes šitie surinkti daiktai bus mūsų ainiams gyvi liudininkai tos karštos meilès, kuria degè mūsų jauna armija kovodama už savo tautos garbę", nurodyta rinkti 1919 m. pabaigoje, dar vykstant Nepriklausomybès kovoms ${ }^{212} .1920$ m. gale, pasibaigus aktyviems karo veiksmams, Lietuvos kariuomeneje dar labiau imta rūpintis karo istorija. $1921 \mathrm{~m}$. sausio $22 \mathrm{~d}$. buvo įsteigta 19 asmenų nuolatinè Karo istorijos kolegija (vadovas gen. ltn. Vladas Nagevičius ${ }^{213}$ ). Jai buvo pavesta „rūpintis taisyklingu pulku istorijos vedimu ir Centrinių Karo Muziejaus ir archyvo organizavimu“"214. 1921 m. Petras Klimas, be kitų istorijos temų, pabrèžè tautos praeities kovų pažinimo svarbą, nes, anot autoriaus, su istorija susipažinusi karta suauga su „protèviais i vieną draugiją ${ }^{215}$. Suprantama, siekiant paskatinti karo istorijos tyrimus ar bent jau istorinès medžiagos rinkimą ir saugojimą, buvo būtina atitinkama agitacija arba švietimas ir informavimas šiais klausimais. Todèl jau 1921 m. Karyje pabrèžiama, kaip kariams reikia išmanyti savo pulko istoriją, pateikta žymių karininkų minčių apie karo istorijos svarbą kariui ir daliniui ${ }^{216} .1921 \mathrm{~m}$. buvo pasiūlyta kiekviename dalinyje ¡kurti nuolatines karo istorijos komisijas, kurios rinktų padalinio istorijos medžiagą, ir išdėstyta 10 punktų komisijų veiklos programa ${ }^{217}$. Tačiau šios komisijos veikè neilgai, nes 1927 m. spaudoje konstatuota, kad 1921-1922 m. daliniuose įsteigtos karo istorijos komisijos, kurių tikslas -

\footnotetext{
${ }^{212}$ Antrai brigadai, 1919 m. gruodžio 15 d. įsakymas Nr. 46. LCVA, f. 1764, ap. 1, b. 3, 1. 60 .

${ }^{213}$ Plačiau apie gen. V. Nagevičiaus veiklą žr.: Generolo gydytojo Vlado Nagiaus Nagevičius gyvenimo ir darbų apžvalga. Red. B. Matulionis. Putnam (Connecticut), 1962.

${ }^{214}$ Kolegiją sudarè: gen. ltn. Maksimas Kattche, gen. ltn. Juozas Kraucevičius, gen. ltn. Valerijonas Ramanauskas, gen. ltn. Vladas Nagevičius, plk. Juozas Litvinas, plk. ltn. Mikas Gedgaudas, plk. ltn. Arvidas Jansonas, plk. ltn. Pranas Šližys, mjr. Leonas Šilingas, kpt. Juozas Papečkys, kpt. Vytautas Steponaitis, kpt. Jonas Laurinaitis, kpt. Antanas Užupis, kpt. Stasys Dirmantas, vyr. ltn. Jurgis Bobelis, vyr. ltn. Juozas Urbšys, veterinarijos gydytojas Kazys Trumpis, karo valdininkas Juozas Grigaitis, Šaulių sąungos atstovas Vladas Putvinskis: İsakymas kariuomenei. Rikiuotès skyrius, 1921, sausio 22, Nr. 17, p. 1.

${ }^{215}$ Klimas, P. Senovès tyrimo uždaviniai ir keliai. Mūsų senové, 1921, Nr. 1, p. 3.

${ }^{216}$ Citatos: Apie pulkų istoriją (Parinktos mintys). Karys, 1921, kovo 24, Nr. 12 (96), p. 137-138.

${ }^{217}$ K-r. K-s, K. Mūsų karo istorijos reikalu. Karys, 1921, gegužès 12, Nr. 19 (103), p. 213-214.
} 
rinkti „viską, kas primena pirmus kariuomenės žygius“, faktiškai jau nebeveikia, ir pasiūlyta atnaujinti jų veiklą ${ }^{218}$.

1922 m. Karyje rašyta, kad „metas jau rimčiau susidominti karo mokslu ir menu" ${ }^{219}$, gana aiškiai išdėstyta, kodèl karo istorija tokia svarbi kariuomenei: „Teisingai ir tiksliai karo paděčiai suprasti reikalingas dar ir karo istorijos artimesnis pažinimas sąryšyje su karo mokslo teorija. “220 Ivardytos karo mokslų plètojimo priemonès: 1) nuolatinė karininkų veikla šioje srityje: referatų rašymas, paskaitos, pranešimai karo istorijos temomis, karo žaidimai; 2) iniciatyva dalị karininkų algų skirti specialiam bibliotekų knygų karybos tematika fondui komplektuoti ${ }^{221} .1923 \mathrm{~m}$. akcentuota "karo mokslo bibliotekos“ svarba kariuomenei ${ }^{222} .1924$ m. Vyriausiojo štabo Karo mokslo skyrius išleido gen. Leono Radaus-Zenkavičiaus knygą apie Pirmąji pasaulinị karą. Jos pratarmejje autorius lakoniškai nusakẻ karo istorijos reikšmę: „Iš karo dalykų ciklo vienintelè karo istorija rodo mums visų karo elementų suderintus veiksmus. Tik karo istorija gali atvaizduoti, kaip veikia, vykdant tam tikrus planus ir sumanymus, netikètumas ir kiti nežinomieji veiksniai, kurių viršininkas negali laikyti save tinkamu savo pareigoms kare eiti, jei jis nèra nors bent kiek susipažinęs su karo istorija, o ypač su Didžiuoju karu. “ Knyga buvo skirta Lietuvos kariuomenès karininkams supažindinti su Pirmojo pasaulinio karo eiga ir naujaja karine doktrina ${ }^{223}$. Generolas karo istorija rèmèsi ir 1922 m. parengtos karinès doktrinos tekste ${ }^{224}$.

1925 m. mjr. Romualdas Burokas ${ }^{225}$ skatino karininkus domètis karo istorija, analizuoti ir lyginti žymiausius mūšius. Kartu apgailestavo, kad

\footnotetext{
${ }^{218}$ Juodvalkis, J. Reikètų! Karys, 1927, vasario 1-8, Nr. 5 (401), p. 46.

${ }^{219}$ V. J. Pasirūpinkim savimi. Karys, 1922, lapkričio 30, Nr. 48 (184), p. 569.

${ }^{220}$ V. Karo vadovybè. Karys, 1922, rugsèjo 15, Nr. 37 (173), p. 441.

${ }^{221}$ V. J. Pasirūpinkim savimi. Karys, 1922, lapkričio 30, Nr. 48 (184), p. 569.

${ }^{222}$ Karo mokslo skyrius, 1923 m. gegužès 5 d. LCVA, f. 929, ap. 6, b. 65, 1. 33.

${ }^{223}$ Radus-Zenkavičius, L. Trumpas Didžiojo karo eskizas. Kaunas, 1924, p. 2.

${ }^{224}$ Jokubauskas, V. Pirmoji Lietuvos Respublikos kariuomenès karinè doktrina ir jos autorius [Radus-Zenkavičius, L. Dèl karo doktrinos prièmimo Lietuvos kariuomenèj (dokumento publikacija)]. Karo archyvas, 2015, t. XXX, p. 176-237.

225 Tuo metu III karo apygardos štabo Rikiuotès dalies vyr. adjutantas, nuo $1925 \mathrm{~m}$. balandžio 4 d. Generalinio štabo I skyriaus viršininkas, nuo 1926 m. tarnavo Karo mokslų valdyboje, 1926-1927 m. redagavo Karị.
} 
Lietuvoje dar neparengta savo šalies karo istorija, nes tai esąs nepelningas, bet, karininko teigimu, kilnus ir reikalingas darbas ${ }^{226}$. Karininkams per atostogas buvo rekomenduojama rinkti medžiagą Lietuvos karo istorijos tematika ${ }^{227} .1927 \mathrm{~m}$. buvo planuojama rengti kursus vyresniesiems karininkams - divizijų ir pulkų vadams ir jų padejejjams, kitų karinių isstaigų vadams, kur, be karo meno, strategijos, taktikos ir kitų disciplinų, būtų dèstoma ir karo istorija ${ }^{228}$. Kariniuose daliniuose buvo skaitomos paskaitos įvairiomis karo istorijos temomis ${ }^{229}$.

1926 m. Karo mokslo skyriaus viršininkas plk. ltn. Juozas Lanskoronskis rašè, kad taktika glaudžiai susijusi su karo istorija, jog ji svarbi ne tik kaip atskira karo mokslo disciplina, bet ir kaip priemonė karinėms operacijoms perprasti. Nuoseklus karo istorijos kursas suteikia žinių karybos išvadoms daryti, bet taktikos teorijos dèsnius irgi būtina iliustruoti istorijos pavyzdžiais. Sprendžiant tam tikras taktikos problemas (nagrinejjant gynybos, puolimo, atsitraukimo ir kt. ypatumus), mokymų su didesniais vienetais (pulkais) metu instruktoriams tenka remtis karo istorijos pavyzdžiais, juos gvildenant mokyti karininkus aiškinti operacijų aplinkybes ir daryti išvadas. Istorinis karinių operacijų nagrinejjimas duoda daugiausia naudos aiškinantis, koks yra ryšys tarp aplinkybių, sprendimo ir vykdymo būdų. Intelektualinio darbo procesas (sprendžiant ịvairius uždavinius ir narinejjant istorijos faktus) leidžia išmokyti karius vadovautis „vadinamąja pritaikomąja taktika, bet ne priprati mų bei šablonų taktika“.

\footnotetext{
${ }^{226}$ Burokas, R. Naujieji norai. Kardas, 1925, sausio 15, Nr. 1 (1), p. 8.

${ }^{227}$ Januška, V. Karininko darbas per atostogas. Kardas, 1926, birželio 20, Nr. 17 (41), p. 272.

${ }^{228}$ Kursai vyresniesiems viršininkams. Kardas, 1926, lapkričio 20, Nr. 32 (56), p. 511.

${ }^{229} 1927$ m. kovo 8 d. po 7-ajame pèstininkų pulke Klaipėdoje, karininkų klube, plk. P. Genio skaitytos karo istorijos paskaitos „Rusu strategijos šansai 1914 m.“ teigta, kad „paskaita buvo labai turininga ir įdomi. Labai vaizdžiai buvo viskas nubraižyta schemoje. Smulkiai išnagrinèti visi rusų strategijos planai, kariuomenės paskirstymas, jų šansai, padarytos klaidos ir atskiri epizodai iš pradžios Didžiojo karo“: Gg. Mūsų kariuomenès gyvenimas. Kardas, 1927, kovo 20, Nr. 7-8 (67-68), p. 111.1927 m. birželio 25 d. Klaipèdos iguloje mjr. Vladas Vanagas skaitė 2 val. paskaitą „Sorykamyšo operacija $1914 \mathrm{~m}$. iš rusų-turkų karo“. Spaudoje teigta, kad „buvo išnagrinèti veiksmai abiejų kariaujančių pusių ir jų geros ir blogos pusès. Tokio turinio paskaitos labai naudingos ir pageidaujamos siekiant išvengti klaidų būsiančiuose karuose“: Nykštukas, J. Mūsų kariuomenès gyvenimas. Kardas, 1927, liepos 10, Nr. 19 (79), p. 273-274.
} 
Taigi karo istorijai, studijuojant taktiką, skirtas išskirtinis dèmesys ${ }^{230}$.

1927 m. Kariuomenès centrinès bibliotekos viršininkas mjr. A. Ružancovas pabrèžè, kad karo istorija karininkams padeda plèsti savo akiratị, deramai suprasti ir ịvertinti ịvairius karo veiksmus. Daugybė Pirmojo pasaulinio ir Rusijos pilietinio karų metu sukauptų dokumentų gulejo archyvuose. Nesant galimybės nuosekliai analizuoti XX a. pradžios karo istoriją, teko tenkintis atskiromis monografijomis ir kartu siekti kuo skubiau "paskelbti svarbiausių ir pamokomųjų operacijų“ tyrimus ${ }^{231}$. 1928 m., agituojant karius rinkti karo istorijos medžiagą, rašyta, kad „kariuomenė, būdama labai svarbiu veiksniu tautos gyvenime, privalo turèti savo praeitųjų dienų išsamesnị pilną vaizdą“. Tikètasi, kad kariuomenei surinkus pakankamai medžiagos ir profesionalūs istorikai imsis rašyti Lietuvos karo istoriją ${ }^{232}$.

Lietuvos valstybingumo atkūrimo, o kartu ir kariuomenès dešimtmečio proga $1928 \mathrm{~m}$. buvo išleista knyga Lietuvos nepriklausomybès 10-mečiui paminèti ${ }^{233}$ - Medžiaga kariškai Lietuvos istorijai: nuo seniausiu laiku, kurioje konstatuota, kad „sunku yra sudaryti gerą bendrą Lietuvos istorijos vadovèli, tai dar sunkiau parašyti Lietuvos kariškosios istorijos vadovèlị", nes nèra nè vieno Lietuvos karo istorijos vadovèlio ar ją apibendrinančio veikalo. Knygoje chronologine seka, be analizės, kritinio juvertinimo ir interpretacijų, remiantis šaltiniais, aprašyta Lietuvos (baltų genčių) karybos istorija nuo priešistorinių laikų iki XIII a. imtinai, o žemaičių atvejis - iki $1422 \mathrm{~m}$. Melno taikos. Sudarytojas plk. Jonas Asevičius-Acukas pažymèjo, kad spèta parengti tekstus tik iki XIV a., nes knygos leidybą finansavo Lietuvos nepriklausomybès atgijimo 10 metu sukaktuvèms ruošti vyriausiasis komitetas, kuris reikalavo, kad leidinys būtų išleistas iki $1928 \mathrm{~m}$. gegužès 15 d. ${ }^{234}$ Knygoje aprašyti sunkumai ir

\footnotetext{
${ }^{230}$ Lanskoronskis. Aukštieji karininkų D. L. K. Vytauto kursai ir jų reikšmè mūsų kariuomenei. Kardas, 1926, rugsėjo 10, Nr. 25 (49), p. 387-388.

${ }^{231}$ R-as, A. Raštų apžvalga. Kardas, 1927, sausio 30, Nr. 3 (63), p. 59.

232 Šipelis. Kary, būk istorijos medžiagos rinkèjas. Karys, 1928, gruodžio 17, Nr. 51 (499), p. 809.

${ }^{233}$ A. R. Medžiaga kariškai Lietuvos istorijai nuo seniausių laikų. Karys, 1928, gegužès 16-31, Nr. 21-22 (469-470), p. 432.

${ }^{234}$ Medžiaga kariškai Lietuvos istorijai: nuo seniausių laikų. Red. J. Acukas. Kaunas, 1928, p. 5-6.
} 
karo istorijos tyrimų lygis puikiai iliustruoja padeti praejus 10 metų po nepriklausomybès ir kariuomenès atkūrimo.

Karo mokslų ir karo istorijos plètrai labai pasitarnavo specializuotų tęstinių mokslo žurnalų leidyba. $1921 \mathrm{~m}$. Lietuvos kariuomenès Generalinio štabo Literatūros skyrius pradejo leisti Mūsų žinyną ${ }^{235}$, kuris buvo „rimtas, grynai karo mokslo žurnalas“236. Iki $1940 \mathrm{~m}$. buvo išleisti 38 tomai (184 numeriai). Mūsǔ žinynas buvo siunčiamas užsienio karo mokslo leidinių redakcijoms - 1932 m. į Estiją, Austriją, Čekoslovakiją, Vengriją, Vokietiją, Olandiją, Belgiją, Prancūziją, Rumuniją, Italiją, Latviją, Šveicariją, JAV, Jugoslaviją, SSRS, Bulgariją ${ }^{237} .1924$ m. Mūsu žinyną karininkai galejo įsigyti su $50 \%$ nuolaida ${ }^{238} .1923 \mathrm{~m}$. V. Steponaičio atestacijoje gen. L. Radus-Zenkavičius rašè, kad redaktoriaus dèka „karo žurnalas „Mūsų žinynas“ susilygino su geriausiais Europos karo žurnalais“239. Karinè vadovybė sieké, kad ši karo mokslų leidinị prenumeruotų ir skaitytų visi rikiuotès karininkai ${ }^{240}$.

$1924 \mathrm{~m}$. planuota karo istorijai skirtą tęstinị leidinị pavadinti Istorijos knygos $^{241}$, tačiau $1925 \mathrm{~m}$. buvo pradètas leisti Karo archyvas. Išskirtini du leidybos etapai - 1925-1929 m. (išleisti 5 tomai) ir 1935-1940 m. (išleisti 7 tomai). Iš viso iki $1940 \mathrm{~m}$. buvo išleista 12 tomų. Karo archyvo 1-ame tome, Redakcijos žodyje, rašoma, kad, atsikuriant Lietuvos kariuomenei, „remtasi Didžiojo karo patyrimais ir pamokymais. Iš kitos pusès, teko taikintis ir grynai vietos, Lietuvos, reikalavimams. Čia ir iškilo savosios kariuomenès istorijos tradicijos klausimas“. Pažymèta, kad „Lietuvos karo istorijos tyrinètojų padètis nèra lengva ${ }^{{ }^{2} 242}$. XX a. 4-ojo dešimtmečio

\footnotetext{
$2351936 \mathrm{~m}$. kovo viduryje buvo išleistas 132-asis numeris, leidinio tiražas svyravo nuo 1000 egz. 1924-1932 m. iki 2600 egz. 1921 m., iš viso per 15 metų buvo išspausdintas 154691 leidinio egz.: „Mūsų Žinyno“ 15 metų sukaktuvès. Karys, 1936, kovo 12, Nr. 11 (886), p. 253.

${ }^{236}$ Leitenantas. Svarbiu, bet užimtu klausimu. Karys, 1923, sausio 12-19, Nr. 2, p. 20.

${ }^{237} 1932 \mathrm{~m}$. Mūsų žinyno kareivių, karininkų bibliotekų ir užsienio redakcijų adresai. LCVA, f. 929, ap. 6, b. 141, 1. 306-307.

${ }^{238}$ Karo mokslo skyrius, 1924 m. spalio 23 d. LCVA, f. 929, ap. 6, b. 65, 1. 50.

${ }^{239}$ Atestacija, $1923 \mathrm{~m}$. sausio 17 d. LCVA, f. 930, ap. 8, b. 288, apv. 1. 57.

${ }^{240}$ Kariuomenès štabas, 1938 m. vasario 15 d. LCVA, f. 929, ap. 1, b. 630, 1. 20.

${ }^{241}$ KMD Centro valdybai, 1924 m. rugpjūčio 14 d. LCVA, f. 889, ap. 1, b. 22, 1. 102.

${ }^{242}$ Redakcijos žodis. Karo archyvas, 1925, t. I, p. 1.
} 
pabaigoje istorikai J. Matusas ir Z. Ivinskis Karo archyva įvardijo kaip vieną iš kelių istorijos žurnalų, leistų tarpukariu ${ }^{243}$. Jo pobūdị $1940 \mathrm{~m}$. atskleide V. Steponaitis, Karo archyvo 13 tomo sudarytojas, kuris P. Lukauskaitei-Jasaitienei rašè, jog laukia jos atsiminimų, kad galètų publikuoti, ir apdairiai nurodè: „Dydžiu prašau nesivaržyti. Juo daugiau smulkmenų, net dokumentų (jei yra), juo geriau. “244

Tačiau šis karo istorijai skirtas tęstinis leidinys nejjo periodiškai, nes susidurta su lèšų stygiumi. 1925 m. V. Steponaitis raportavo, kad Mūsu žinyne netilpo visa gauta medžiaga, todel ikurtas Karo archyvas - naujas, „nereguliariai einąs periodiškas leidinys“, kuriame, „kol Lietuvoje nèra specialiai istorijai skirto laikraščio, „Karo archyve“ bus duodama vietos ir bendros Lietuvos istorijos rašiniams. Šiaip gi „Karo archyvas“ skirtas

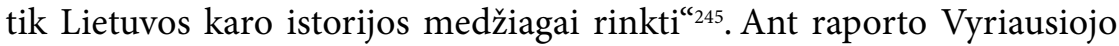
štabo viršininkas plk. ltn. Jonas Gricius 1925 m. sausio 20 d. užrašè: „Iš kur imsit lèšas? Prašau mane asmeniniai referuoti klausimą. Ar negalima esamąją medžiagą patalpinti trijuose periodiniuose kariškuose leidiniuose? Tuo labiau kad tos medžiagos labai mažai turite“, o sausio 22 d. - rezoliuciją: „Sutinka.“246

$1928 \mathrm{~m}$. Vyriausiojo štabo Karo mokslo valdybos viršininko gen. št. plk. Vlado Skorupskio nurodymu, atsižvelgiant $\mathfrak{i}$ karo istorijos svarbą karininkams ir siekiant, kad Mūsų žinynas „būtų įdomesnis ir naudingesnis skaitytojams [1927 m. jų buvo 489], prie jo programos dar pridedamas labai svarbus dalykas - karo istorija, kuriai ligi šiol atstovavo „Karo archyvas“. Pastarasis dèl brangumo buvo sunkiai prieinamas karininkams, todèl ir karo istorija jiems buvo pasidariusi tolima. Kad karininkai galètų lengviau lavintis ir istorijos srity, „Karo archyvas“ su visa savo programa jjungiamas $\mathfrak{i}$ „Mūsų žinyną ${ }^{\text {"247 }}$. Taigi publikacijos karo istorijos tema buvo nukreiptos ị Mūsų žinyna, tačiau specializuoto karo istorijos leidinio - Karo archyvo - leidybos klausimas iš dienotvarkès ne-

\footnotetext{
${ }^{243}$ Gieda, A. Istoriografija ir visuomene: istorika, istoriko profesijos ir istorinès kultūros aspektai Lietuvoje 1904-1940 m. [daktaro disertacija]. Vilnius, 2013, p. 277-279.

${ }^{244}$ Steponaičio 1940 m. sausio 31 d. laiškas. LCVA, f. 929, ap. 6, b. 242, 1. 48.

${ }^{245}$ Mjr. V. Steponaičio 1925 m. sausio 10 d. raportas. $L C V A$, f. 929, ap. 6, b. 75, 1. 23.

246 Ten pat, 1. 24.

${ }^{247}$ Vyriausiojo štabo valdyba, 1928 m. sausio 12 d. LCVA, f. 1764, ap. 1, b. 138, 1. 1.
} 
dingo. 1932 m. V. Steponaitis dèl pastarojo leidybos kreipèsi ị Vyriausiojo štabo Spaudos ir švietimo skyriaus viršininką plk. Juozą Šarauską. Jis konstatavo, kad Mūsų žinynas yra vienintelis Lietuvoje leidinys, kuriame „tenka paliesti visų ginklų rūšių teorijos klausimus“, o karo istorijai ir atsiminimams jame vietos nelieka, nes prioritetas - straipsniai karo „teorijos klausimais“, ir paprašè leidimo išleisti naują Karo archyvo tomą, iš Mūsų žinynui skirtų lèšu paėmus 6 500-8 000 Lt. Tačiau rezoliucijoje buvo parašyta: „Dèlei lèšų stokos šiais metais „Karo archyvą“ leisti negalima bus." ${ }^{248}$

Minètuose leidiniuose buvo plačios galimybès skelbti aktualius verstinius užsienio autorių straipsnius, taip pat Lietuvos tyrèjų darbus, atsiminimus ir kitus šaltinius.

1925 m. KMD iniciatyva pradètas leisti Kardas, vadintas karininkų laikraščiu. Jis buvo „panašus ị specializuotą karininkų švietimo žurnalą“. Daugelyje jo publikacijų pabrèžta mokslo naujovių, šviečiamojo darbo kariuomeneje svarba. Periodiniame leidinyje pradètos skelbti ir publikacijos istorijos temomis, aptarti istorinès medžiagos kaupimo ypatumai ${ }^{249}$.

Karo istorijos temomis rašyta ir kituose kariniuose periodiniuose leidiniuose. Per pirmuosius 15 leidybos metų Karyje buvo išspausdinta per 560 šios tematikos straipsnių ${ }^{250}$. Tačiau tokio pobūdžio tekstai buvo spausdinami ir kituose kariniuose leidiniuose. Iki $1940 \mathrm{~m}$. visuose periodiniuose kariniuose leidiniuose straipsnių karo istorijos temomis buvo paskelbta gerokai daugiau, tačiau dažnai tai buvo populiarūs tekstukai, o ne konceptualūs akademiniai tyrimai, paremti nuodugnia analize.

\section{III.}

Istorikui, ieškant atsakymų i išsikeltus klausimus, sprendžiant aktualias istoriografijai ar visuomenei problemas, svarbu ne tik surinkti ir susisteminti medžiagą (nors tai irgi tam tikrų specialių igūdžių reikalaujanti

\footnotetext{
${ }^{248}$ Plk. ltn. V. Steponaičio 1932 m. kovo 31 d. raportas. LCVA, f. 929, ap. 6, b. 141, 1. 201. ${ }^{249}$ Juzefovičius, R. Istorine švietejiška Karo mokslų draugijos veikla 1923-1933. Karo archyvas, 2002, t. XVII, p. 185-186.

${ }^{250}$ Ružancovas, A. Mūsų karų ir kariuomenès istorija „Karyje“ (1919-1934 metų bibliografija). Kario priedas Nr. 21. Karys, 1934, gegužès 24, Nr. 21 (792), p. 1-16.
} 
veikla), „viską“ smulkiai aprašyti, bet ir „prakalbinti šaltinius“, t. y. nuspręsti, kas ir kaip bus daroma su sukauptų empirinių duomenų bagažu, kokia bus tyrimo metodologine prieiga ir kokios jai igyvendinti pasitelkiamos priemonès. Dažnai ị šiuos klausimus daug geriau atsakyti padeda praktinè patirtis nei teoriniai veikalai ir ịvairios metodologinès rekomendacijos, tačiau be jų gali tekti „išradinèti dviratị“. Tarpukariu diskutuota istorijos mokslo metodologijos klausimais, analizuotos istorijos mokslo raidos kryptys ${ }^{251}$ ir t. t., išdėstyti mokslinio darbo metodikos pagrindai ${ }^{252}$. Plačiau istorijos metodologijas tarpukario Lietuvoje yra aptarę istorikai A. Ragauskas ${ }^{253}$ ir P. Lasinskas ${ }^{254}$. O apskritai „XX a. trečiojo-ketvirtojo dešimtmečių lietuviškoji istoriografija išgyveno neabejotiną kiekybinị ir kokybinị šuolį “255.

Tarpukariu Lietuvos istorikai akcentavo etnocentristinę istorijos ty-

${ }^{251}$ Jakštas, A. Kas yra istorija. Ateitis, 1926, rugsejjis-spalis, Nr. 9-10, p. 439-445; Totoraitis, J. Istorijos metodologijos užrašai. Paskaitos, skaitytos 1929 metu pavasario semestre Lietuvos universitete. Kaunas, 1929; Karsavinas, L. Istorijos teorija. Kaunas, 1929; Karsavinas, L. P. Istorijos mokslo krizè. Vairas, 1930, balandis, Nr. 4, p. 8-14; Štuopis, P. Mūsų istorija. Naujoji Romuva, 1931, gegužès 17, Nr. 20, p. 468-470; Jakštas, J. Istorijos mokslas ir gyvenimas. Vairas, 1932, spalis, t. VI, Nr. 10, p. 84-88; Jakštas, J. Vertybės istorijoj. Vairas, 1934, liepa, t. XI, Nr. 7, p. 257-266; Ivinskis, Z. Lietuvos praeities ir dabarties kryžkelès. Naujoji Romuva, 1933, kovo 26, Nr. 117, p. 289-291; Štuopis, P. Tautinès istorikų pareigos. Akademikas, 1933, gruodžio 1, Nr. 16, p. 307-309; Ivinskis, Z. Lietuvos istorijos problemos. Naujoji Romuva, 1935, kovo 31, Nr. 12-13 (220-221), p. 288-292; Stein, A. Istorijos mokslo krizè. Vairas, 1936, liepa-rugpjūtis, Nr. 7-8, p. 737-745; Matusas, J. Kiek pažengė Lietuvos istorijos mokslas. Pasaulio lietuvis, 1938, balandžio 1, Nr. 7 (10), p. 147-148; Valiukènas, A. Mūsų istorijos vertinimo reikalu. Akademikas, 1938, birželio 15, Nr. 11-12, p. 247-249; Jakštas, J. Istorijos mokymo tikslai. Židinys, 1939, sausis, t. XXIX, Nr. 1, p. 71-80; P. J. Istorikas istorijoje. Židinys, 1939, gruodis, t. XXX, Nr. 12, p. 725-727; Ivinskis, Z. Aktualieji mūsų praeities klausimai ir jų ịtaka dabarčiai. Kardas, 1939, birželio 15, Nr. 12 (314), p. 316-325.

252 Šalkauskis, S. Bendrosios mokslinio darbo metodikos pradai. Židinys, 1926, t. III, Nr. 1-2, p. 57-77; t. III, Nr. 3, p. 157-175; t. III, Nr. 4, p. 227-247; t. III, Nr. 5, p. 313-333; t. III, Nr. 6-7, p. 458-477; t. IV, Nr. 8-9, p. 61-68; t. IV, Nr. 12, p. 326-347.

${ }^{253}$ Ragauskas, A. Keletas pastabų dèl istorijos metodologijos tarpukario Lietuvoje. Lietuvių kataliku mokslo akademijos metraštis, 2001, t. XIX, p. 59-70.

${ }^{254}$ Lasinskas, P. Istorijos mokslas Vytauto Didžiojo universitete 1922-1940 metais. Vilnius, 2004.

${ }^{255}$ Gieda, A. Istoriografija ir visuomene: istorika, istoriko profesijos ir istorinès kultūros aspektai Lietuvoje 1904-1940 m. [daktaro disertacija]. Vilnius, 2013, p. 404. 
rimų prieigą. Petras Klimas pabrèžè, kad „statyti Lietuvos valstybę be istorinès Lietuvos individualybès pažinimo reikštų eiti pusiau užrištomis akimis ị tikslą, kurio ne tik neprimatai, bet ir neprijauti““256. 1932 m. Adolfas Šapoka paskelbè plačiai žinomą tezę apie būtinybę „rasti lietuvius Lietuvos istorijoje“257. 1933 m. Povilas Štuopis pažèrè kritikos, kad „per 16 nepriklausomybės metų jaunoji Lietuva nesusirado nė vieno istoriko, kuris būtų teikęsis padovanoti savo tèvynei gražią rašytinę jos istoriją", o jei „panorèsi pažinti Lietuvos praeitị, tai lietuvių kalbos tau nereikès“, nes, net norint „sužinoti, ką apie mūsų Aistuvą rašo savo disertacijose ir mūsų jaunieji istorijos daktarai“, reikia vokiečių kalbos ir t. t. ${ }^{258} 1935$ m. J. Matusas rašè, kad, paanalizavus kaimyninių didžiųjų valstybių istorijos mokslą, galima „isitikinti, kad jis aiškiai remia savo krašto plačiai suprastą tautinę politiką. Iš to savaime aiškūs mūsų istorijos uždaviniai. Ji turi siekti objektyvios tiesos, bet turi būti aiškiai lietuviška. Būtinas reikalas mùsų istorijos mokslui turèti galvoje visas gyvąsias istorines tautines problemas“, t. y. uniją su Lenkija ir Mažosios Lietuvos gyventojų lietuvių kilmę bei paplitimo arealą ${ }^{259}$. Kita vertus, Z. Ivinskis kūrè kitokią koncepciją, pagal kurią pirmiausia būtų nustatoma Lietuvos istorijos vieta Europos istorijoje, nes kitaip „Lietuvos istorija išeina lyg kokia sala visuotinès istorijos jūroje“, taigi rème 1919 m. Stasio Šalkausko iškeltą Lietuvos „ant Rytų bei Vakarų“ koncepciją. Anot Alfredo Bumblausko, Z. Ivinskis „formulavo europocentristinę Lietuvos istorijos sampratą ${ }^{260}$. Istoriko Vinco Trumpos nuomone, tarpukariu Lietuvoje menkai analizuotos istorijos filosofijos ir metodologijos problemos, o visuomeneje būta nuomonių, kad

\footnotetext{
${ }^{256}$ Klimas, P. Senovès tyrimo uždaviniai ir keliai. Mūsu senové, 1921, Nr. 1, p. 5.

257 Šapoka, A. Raskim lietuvius Lietuvos istorijoje. Naujoji Romuva, 1932, gegužès 22, Nr. 21 (73), p. 481-482; Apie „lietuvių paieškų istorijoje“ tarpukariu problemą taip pat žr.: Selenis, V. Apie „lietuvių ieškojimą Lietuvos istorijoje“ ir tautinę politiką. Kultūros barai, 2009, Nr. 6, p. 26-30.

258 Štuopis, P. Tautinès istorikų pareigos. Akademikas, 1933, gruodžio 1, Nr. 16, p. 307.

${ }^{259}$ Matusas, J. Istorijos mokslas ir tautine politika. Vairas, 1935, gruodis, t. XV, Nr. 12, p. 394-395.

${ }^{260}$ Bumblauskas, A. Z. Ivinskis ir Lietuvos istoriografijos paradigmos. Kultūros barai, 1992, Nr. 3, p. 10-13. Plačiau apie Z. Ivinskio požiūrị ị istorijos tyrimus ir jo koncepcijas žr.: Bumblauskas, A. Penkios Zenono Ivinskio teorinès novacijos. Lietuvos istorijos studijos, 1997, Nr. 4, p. 14-34.
} 
netikslinga skirti finansavimą istorikų mokslinei veiklai, leisti istorijos veikalus ir išlaikyti Istorijos katedrą universitete ${ }^{261}$. Pastaroji tendencija (apskritai rodanti požiūrị i socialinius ir humanitarinius mokslus) aktuali ir XXI a. Lietuvai ${ }^{262}$.

Karo istorijos srityje, be bendru istorijos mokslo metodologinių rekomendacijų ir tyrimo krypčių, pateikta nemažai metodinių patarimų ir nurodymų, pavyzdžių, kaip dirbti mokslinį darbą. Tačiau stokota kvalifikuotų istorikų, galinčių tinkamai atlikti karo istorijos tyrimus, rašyti dalinių istorijai skirtas monografijas, todèl pirmasis uždavinys buvo rinkti joms medžiagą. Siūlyta rengti ir leisti specialius dalinių istorijos vadovèlius, kuriuose būtų pateikti svarbiausi faktai, mūšių, kuriuose karinis vienetas dalyvavo, schemos ${ }^{263}$. Pastebėta, kad rašant pulkų istorijas reikia aptarti ir bendrą istorinị kontekstą, tokiose knygose turèjo būti analizuojamos dalinių karinès operacijos, tačiau kartu įvertinami ir kiti dalini veikę veiksniai - jo organizacija, santykiai su visuomene ir t. t. ${ }^{264}$ 1923 m. ltn. Petras Biržys spaudoje, pabrèžęs, kad dalinio istoriją parašyti gali ne kiekvienas, bet medžiagą gali rinkti visi, išdèstė rekomendacijas, kaip klasifikuoti istorinę dalinių medžiagą ${ }^{265}$. Jomis vadovautis siūlè ir KMD istorijos sekcijos nariai.

1926 m. sausio-vasario mèn. KMD istorijos sekcijos nutarimu mjr.

\footnotetext{
261 Trumpa, V. Savosios istorijos keliais. Kaunas, 1937, p. 4.

262 Plačiau žr.: Gedutis, A.; Kraniauskas, L. Socialinių ir humanitarinių mokslų vertinimo praktikos Lietuvoje. Klaipėda, 2013. Lietuvos mokslo taryba 2016 m. skyrè lèšų projektui Humanitarinių mokslu reikšmé: globalūs argumentai ir lituanistine specifika, kurio metu filosofai dr. Kęstutis Kirtiklis ir dr. Aldis Gedutis nagrinèjo „humanitarinių mokslų reikšmès, vertès ir naudos klausimus globalaus ir lituanistinio diskursų sandūroje“: Kartu su rudeniu... [2016 09 08].< http://www.ku.lt/smf/2016/09/07/kartu-su-rudeniu-i-ku-socialiniu-pokyciu-studiju-centra-atkeliauja-nauji-mokslo-projektai-ir-iniciatyvos/ > .

${ }^{263}$ Keblaitis, A. Dalių istorijų reikalu. Kardas, 1934, spalio 15, Nr. 20 (197), p. 397-398.

264 Ž. L. Dèl pulkų istorijų rašymo metodų. Kardas, 1934, rugsèjo 15, Nr. 18 (195), p. 357. 265 1) Dalies užgimimas, atsiradimas. 2) Pirmi savanoriai arba mobilizuotieji. 3) Dalies pavadinimas - krikštas. 4) Skaičius žmonių - dalies jègos. 8) Dalies vadai. 6) Stovyklos vieta. 7) Ginklai, amunicija, maistas. 8) Operacijos. 9) Laimejimai ir nepasisekimai. Aukos. 10) Poilsiai ir rezervai. 11) Pulko ligoninè. Gydytojai, jų darbai. 12) Pulko teismas. 13) Kultūros ir švietimo komisija. 14) Žuvusių pulko karių sąrašas. 15) Pulko karininkų, karo valdininkų, karo gydytojų, karo kapelionų sąrašas: Biržys, P. Pulko istorija. Karys, 1923, rugsèjo 20-26, Nr. 38 (226), p. 425-426.
} 
P. Ruseckas paskelbė rekomendacijas rašantiems karinių dalinių istorijas ir atsiminimus. Jis pažymejjo, kad „dalių istorijos rašymo toliau atidèlioti negalima ir nèra reikalo", nes kariuomenè 1923 m. buvo reorganizuota i taikos meto kariuomenę, o tai sudaro puikias sąlygas dirbti ši darbą, kadangi „istoriją rašyti ypač patogu, kai prie jos rašymo gali prisidèti jos dalyviai“. Buvo išskirti trys etapai: 1) pasiruošimo darbui - susipažinimas su Lietuvos istorija ir karo istorijos istoriografija; 2) medžiagos rinkimas istoriografinès ir šaltinių, susipažįstant su kariuomenès ịsakymais ir veiksmų „reliacijomis“, kartografine medžiaga, memuaristika; 3) medžiagos sisteminimas ir istorijos rašymas, laikantis šios sistemos: a) kariuomenès kūrimas Vilniuje iki pasitraukimo ị Kauną, b) karas su bolševikais (iki 1920 m. sausio), c) karas su bermontininkais (iki 1919 m. gruodžio 15 d.), d) santykiai ir karas su Lenkija. Taigi siūlyta probleminio tyrimo prieiga, pažymint, kad „ne visuomet galima bus ją suskirstyti čia paduota sistema, bet reikès rašyti iš dalies ar vien chronologijos tvarka“. Taigi aiškiai atskirtos probleminio ir chronologinio tyrimo metodologinès prieigos galimybès, pirmenybę teikiant pirmajam ${ }^{266}$. Siekiant išvengti klaidų ir netikslumų, siūlyta recenzavimo ir viešo aprobavimo sistema - „duoti perskaityti vienam kitam karininkui, kuris galètų klaidas pastebèti ar atitaisyti, o paskui reikia pačiam paskaityti, dar ir visiems dalies karininkams jų debatams“. Buvo pabrèžiama atsiminimų svarba rengiant karo istorijos monografijas, rašantiems atsiminimus siūlyta laikytis istorijos darbo rašymo metodinių patarimų, paliekant daugiau laisvès atsiminimų autoriams ${ }^{267}$. Apibendrindamas rekomendacijas rašantiems karo istoriją ir atsiminimus, P. Ruseckas teigè, kad „darbas čia siūlomas didelis ir sudètingas, bet gyvas, įdomus ir mums brangus. Jei ji apsiimsime dirbti - padarysime visai lengvai, nes kiekvienas dirbs tik savo dalį, kuri yra ne didžiausia ir ne sunkiausia. Todèl kiekvienas tą savo darbo dalị tegul ir atlieka"268.

1926 m. buvo pranešta, kad „istorijos sekcija šiokių tokių nurodymų paruošè; tai buvo paskelbta Karde ir bus daugiau skelbiama. Apie me-

\footnotetext{
${ }^{266}$ Ruseckas, P. Dèl dalių istorijos ir atsiminimų rašymo. Kardas, 1926, sausio 30, Nr. 3 (27), p. 39-41.

${ }^{267}$ Ruseckas, P. Dèl dalių istorijos ir atsiminimų rašymo. Kardas, 1926, vasario 10, $\mathrm{Nr} 4$ (28), p. 54.

268 Ten pat, p. 56.
} 
džiagos karo istorijai rinkimą daug nurodymų duoda mjr. Tarasenka"269. 1927 m. Mūsų žinyne buvo perspausdintas rusų generolo Andrejaus Zajončkovskio ${ }^{270}$ straipsnis apie karo istorijos tyrimų metodiką, skaitytojams pabrèžiant, kad „karo istorijos tyrinejjimo metodikos klausimas yra aktualus ir mums [Lietuvai - V. J.]“. Šio generolo teigimu, kariuomenei būtina nurodyti vystimosi kryptị, tačiau tai galima padaryti tik remiantis karine patirtimi - istorija, o jos igyti „galima tik per karą, kuris kainuoja ne tik šimtus milijonų, bet tada iškyla tautos gyvavimo ar negyvavimo klausimai. Štai kodèl mes turime būti atsargūs su išvadomis ir tas išvadas galime daryti tik pasirèmę praeities ir dabarties patyrimu“. Buvo ịvardyti trys karo istorijos tyrimo etapai: 1) faktinès medžiagos išdèstymas; 2) medžiagos analizė ir išvadų pateikimas; 3 ) turimų išvadų pritaikymas esamuoju laiku. Konstatuota, kad, remiantis visapusiška faktine medžiaga, „daromos išvados šiai dienai ir netolimai ateičiai“. Autorius glaustai aptare karo istorijos tyrimo eigą nuo medžiagos rinkimo, klasifikavimo iki tyrimo ribų apsibrèžimo. Be to, padarè išvadą, kad „karo istorija yra griozdiška, tokių knygų mažai kas teperka, jos komercijos nèra eiklios, bet be tinkamo karo istorijos plètojimo karybos negalima pastatyti ant tinkamo pagrindo ${ }^{\text {“271 }}$. Ši problema išlieka aktuali ir yra susijusi su karo kaip reiškinio daugiapusiškumu ir sudètingumu, todèl tokio pobūdžio tyrimai turi aprèpti labai daug smulkmenų (pvz., geografines ir gamtines sąlygas, pajègų sudètị, jų moralę, aprūpinimą, vietos gyventojų veiksnị, dalinių judejjimo kryptis ir tempą, užimamas pozicijas ir t. t.), priešingu atveju nebus i̇manoma pateikti ateities karininkams, planuosiantiems karo veiksmus, vertingos analizès. Todèl nuolatos tenka ieškoti pusiausvyros tarp sintezès ir empirinių tyrimų. J. G. B. Droysenas pažymėjo, kad 1870-1871 m. Prancūzijos-Prūsijos karas buvo geriausiai istorijoje dokumentuotas karas ir tai Vokietijos generaliniam štabui leido parengti

\footnotetext{
${ }^{269}$ Januška, V. Karininko darbas per atostogas. Kardas, 1926, birželio 20, Nr. 17 (41), p. 272.

${ }^{270}$ Rusijos imperijos ir SSRS generolas, karo istorikas ir teoretikas (Андрей Медардович Зайончковский, 1862-1926 m., iki mirties buvo M. V. Frunzès karo akademijos profesorius).

${ }^{271}$ Zajončkovskis, A. Metodika karo istorijai tyrinèti. Mūsų žinynas, 1927, t. XII, Nr. 36, p. 314-320.
} 
labai išsamią jo istoriją, tačiau, nepaisant to, daugybè faktų liko nepanaudoti, nes daug karininkų žuvo, nespejję parašyti raportų, ir t. t. Todèl tik susipažinus su turima medžiaga, kritiškai ją ịvertinus, galima ịvardyti problemas, ieškoti atsakymų i iškeltus klausimus ${ }^{272}$, nes aprèpti visų detalių neimanoma, net tikslingai to siekiant karo istorijos (operacijų ir taktikos) tyrimo metu.

$\mathrm{XX}$ a. 3-iajame dešimtmetyje daliniuose veikè 4 asmenų karo istorijos komisijos, be to, buvo paskirti karininkai dalinio istorijai rašyti. Juos būtų galima vadinti metraštininkais. Tačiau 1926 m. atkreiptas dèmesys i tai, kad karo ir kariuomenès istorija - tai du skirtingi dalykai, taigi ir šių komisijų, kaip ir dalinių metraštininkų, funkcijos yra skirtingos, nors dažnai suvokiamos kaip identiškos. Rekomendacijose išsamiau paaiškinta, kad „karo istorija yra neįmanoma, net pradèti rašyti, be kariuomenès istorijos. Kariuomenès istorija turètų būti daugiau albuminio pobūdžio. Joje turi būti teisingai, tikrai ir smulkiai surašyti visi kariuomenės įvykiai. Tie ịvykiai turi būti iliustruoti piešiniais ir fotografijomis. Ypatingo dèmesio reikia kreipti ị dalių operacijas, kariuomenès teismą, karo komendantūras. <...> Tiktai turèdami kariuomenès istoriją, galime imtis rašyti karo istoriją. Lietuvos karo istorijos uždavinys - apibūdinti visapusiškai karą, jo priežastis, jo eigą, laimejjimą ar nepasisekimą. Todèl skubus ir neatidèliotinas reikalas pirmučiausia surinkti medžiagą ir parašyti pulkų ir kariuomenès istoriją“.

Konstatuota, kad esama padetis netoleruotina, nes per ketverius metus dalinių metraštininkai ir karo istorijos komisijos nieko apčiuopiamo nenuveikè. Siūlyta paskirti karininką, kuris rinktų kariuomenės istorijos medžiagą ir palaikytų ryši su dalinių metraštininkais ${ }^{273}$.

1927 m. Mūsų žinyne išspausdintame verstiniame straipsnyje aptarta istorizmo reikšmė atliekant karo istorijos tyrimus, teigiant, kad „istorizmas neduoda karo minčiai sustingti, apsitraukti neveiklumo rūdimis “ ${ }^{274}$. $1928 \mathrm{~m}$. buvo išverstas ir kariuomenès leistame karo mokslo ir istorijos žurnale Mūsǔ žinynas publikuotas karybos teoretiko, Rusijos (SSRS)

\footnotetext{
272 Дройзен, И. Г. Историка. Санкт-Петербург, 2004, с. 224.

${ }^{273}$ Biržys. Karo ir kariuomenès istorija. Karys, 1926, spalio 13-19, Nr. 42 (386), p. 349-350.

274 Toporkov. Istorizmas ir karo dalykai. Mūsų žinynas, 1927, t. XII, Nr. 35, p. 164-173.
} 
gen. Aleksandro Svechino tektas apie karo istorijos tyrimus, kuriame teigiama:

„Iš istoriko reikalaujame drąsios, naujos ir mus liečiančios minties net ir tada, kada kalbėsime apie senovès Graikiją ar Romą. <...> Pasiruošimas karui, ar jis lies kuopos pasiruošimą, ar visos valstybès pasiruošimas yra pagrịstas mūsų žiniomis apie buvusius karus. <...> Visų karo dalykų pagrindas - istorija. Kai kada mums atrodo, būk mūsų statutai, mūsų operacijų ir taktiškų darbų tyrinejjimai yra savistovaus, racionalaus mąstymo vaisius. Ši iliuzija ypatingai dideja, jei tas darbas neina savarankiškai, bet yra kompiliuojamas ir varomas, mokantis iš kitų kariuomenių. <...> Dabar evoliucija eina greitu tempu. Ir jei atsisakytumème tyrinèti savo istoriją, tai tektų šauktis „variagų“ pagalbos ir griebtis svetimos karo literatūros vertimų. Ignoruodami istorijos tyrinejjimą ir originalius karo istorijos darbus mes netoli tenueitume. Labai atsiliko panašūs karybos aiškintojai, kurie, skolindamiesi iš kitų, nurodinèja taktikos ir operacijų reorganizacijos būtinumą. Atsisakydami savarankiško istorijos patyrimų svarstymo, būtinai pavèluotai kartosime tą, ką daro mūsų priešai, o kartodami nedarysime pažangos nei politikoj, nei ekonomikoj, o tuo labiau karyboj. <...> Karo istorijos darbai reikalingi kariuomenès mokytojams ir kūrèjams, nes jie geriau paruoš karui ir bus geriau suprasti ir savo mokinių. "275

Taigi karo istorija ir jos išmanymas turètų užkardyti galimas klaidas, nes padeda ịvertinti, kaip gali būti igyvendinti praktiškai vienokie ar kitokie sprendimai ir kokią sukelti sąjungininkų ir priešų reakciją, pagaliau kaip elgsis savos karinès pajègos ir piliečiai, susidūrę su tam tikrais iššūkiais ir grèsmèmis. Daugumai žinoma, kad didžiausias menas karyboje gebejjimas mokytis iš priešo klaidų, todèl ir karo istorijos tyrimai turi apimti ne tik „savo“, bet ir eventualių priešų patirtị. Tai turètų būti aksioma apsibrèžiant karo istorijos tyrimų metodologines prieigas. Analizuojant „savų“ pajègų veiksmus kartu būtina perprasti ir priešų veikimą laikantis jau minèto „homeriškojo nešališkumo“.

1936 m. Mūsų žinyne buvo paskelbtas iš prancūzų kalbos išverstas plk. Alberto Grasseto 1928 m. straipsnis su metodiniais nurodymais, kaip rašyti kautynių monografiją. Jis aptarẻ karo istorijos reikšmę, monografijos

${ }^{275}$ Svečin, A. Karo istorijos tyrinejjimas (iš rusų kalbos vertẻ R. Burokas). Mūsų žinynas, 1928, t. XIV, Nr. 41, p. 155, 157, 158. 
autoriui svarbias profesines kompetencijas, kritiškai pažvelge i atsiminimus rašančiojo gebejjimą atsiriboti ir objektyviai įvertinti padètị. Pateikè patarimų, kaip rinkti ir klasifikuoti medžiagą, atkreipe demesị ị būtinybę kritiškai vertinti faktus ir neskubèti daryti išvadų neturint tikslaus ịvykių vaizdo. Siūlè tekstą suredaguoti taip, kad jis būtų kuo patrauklesnis skaitytojui. Pulkininko nuomone, „vienintelis metodas“, kuris gali padaryti kautynių monografijas naudingas, - tai „viską - save ir laiką - pašvęsti teisybės ieškojimui“ ir nepamiršti svarbiausios sąlygos, - kad „istoriniai kūriniai turi būti rašomi savanorių su pamėgimu“, t. y. atmetė galimybę tarnyboje kažkam nurodyti imtis karo istorijos tyrimo ir rašymo ${ }^{276}$.

1936 m. Kariuomenès štabo Karo istorijos dalis pateikè rekomendacijas, kaip rašantieji atsiminimus turètų aprašyti kautynes. Tekste turètų būti nurodyta: a) vietovės ypatybės, turejjusios reikšmès veiksmams; b) su kokiais daliniais ir kada teko veikti; c) savo pajègų padètis, dalių sudètis, materialinè ir moraliné būklè, aprūpinimo ir tiekimo tvarka, ypatumai; d) žinios apie priešą, kaip jos buvo renkamos ir tikrinamos; e) kokie buvo gauti aukštesniosios vadovybės įsakymai ir direktyvos; f) kada, kokiomis sąlygomis teko priimti sprendimus, duoti ìsakymus, koks buvo jų turinys; g) aprašyti operacijos eigą, priežastis ir duotų įsakymų vykdymo padarinius; h) kokia buvo gyventojų (šaulių, partizanų, šnipų) pozicija ir veikla, kokią ịtaką tai padare karinei operacijai; i) atsiminimų autoriaus subjektyvios išvados. Aprašant kariuomenès dalinių, štabų ir įstaigų formavimą turejo būti nurodyta: a) kieno ir kokiais ịsakymais remiantis pradètas formavimas; b) bendradarbiai ir materialinis įstaigos aprūpinimas; c) veiksniai, trukdę dirbti, priešo ịtaka; d) suformuoto vieneto veiklos chronologinès ribos ${ }^{277}$.

1938 m. Mūsǔ žinyne buvo paskelbtas išsamus karo mokslo tyrimų vykdymo planas, pažymint, kad karo meną galime pažinti tik lygindami jị su praejjusių laikų patirtimi. O tam būtina atlikti mokslinị istorijos tyrimą. Plane nurodyti trys klasikiniai tyrimo etapai: 1) medžiagos rinkimas; 2) jos apdorojimas ir 3) darbo sintezė, kuri ịvardyta kaip mokslinio dar-

\footnotetext{
${ }^{276}$ Grasset, plk. Kaip rašyti kautynių monografiją. Comment mettre sur pied la monographie de combat (iš prancūzų kalbos vertè kpt. Šalkauskas). Mūsų žinynas, 1936, t. XXX, Nr. 134, p. 462-473.

277 Nurodymai atsiminimus rašantiems. Kardas, 1936, liepos 15, Nr. 14 (243), p. 390.
} 
bo esmè, pateikiant individualius vertinimus. Pabrèžta, kad karo istorijos darbuose būtina „tiksliai nustatyti atskirus istoriškus faktus ir jų savitarpę priklausomybę bei ryšį“. Pažymèta, kad strategijos ir taktikos tyrimuose, remiantis istorijos analize, svarbu atskleisti pagrindinius „karinès veiklos principus, jų priklausomybę nuo ịvairių socialinių, psichologinių ir techninių faktorių “278.

1938 m. išdèstytas ir Lietuvos kariuomenès štabo Spaudos ir švietimo skyriaus Karo istorijos dalies požiūris ị karo istorijos tyrimus ir jų itaką nacionalinei karybai:

„Jokiu būdu negalima manyti, kad istorija yra nukreipta tik ị praeitị. Istorija nèra vien tik mąstymas apie praeitį, bet teisingai suprastas istorijos mokslas apima dabartị ir ateitį. Klaidinga būtų mokytis karybos vien tik iš karų istorijos, nes taktika, strategija ir karo technika nuolatos kinta, bet vis delto patys pagrindiniai karybos principai palieka tie patys. Karo istorija nurodo, kaip tie pagrindiniai karybos principai buvo taikomi amžių eigoje. Šių dienų strategija ir taktika negali būti taip sau iš piršto išlaužta, ji paremta ne abstraktiniu protavimu, bet kariniu patyrimu, buvusių karų istorija. Šių dienų strategija ir taktika yra ilgo atsiradimo proceso padarinys, jos aprèžtos ne tik dabarties, bet ir praeities sąlygų.

Skirtingos yra kario ir mokslininko istoriko pažiūros ị karo istoriją. Istorikas mokslininkas tyrineja karo istoriją abstraktiniu arba daugiau teoriniu atžvilgiu, jis ieško vien istorinès tiesos, nedarydamas jokių praktinių išvadų. Jis analizuoja buvusius karus, visiškai nesiūlydamas jokių receptų ateities veiksmams. Žinoma, istoriko teoriški samprotavimai gali paveikti kito praktiką, kūrybinę mintị, bet istorikas tuo nesirūpina. Praktines išvadas istorikas palieka daryti patiems kariams. Karys studijuos karo istoriją daugiau praktiniu atžvilgiu, joje jis ieškos karinio patyrimo, kuris igyjamas kare arba bestudijuojant karo istoriją. Kario studijos nukreiptos ne vien ị praeitị. Kariui reikalingas patyrimas, praktinis dèsnis, tam tikras išeities punktas, kurị jis galètų padèti būsimųjų veiksmų pagrindu.

Didysis karys Napoleonas, paklaustas, kaip reikia pasidaryti geru karo vadu, visada siūlè mokytis ne strategijos, bet karo istorijos. Taigi, karu istorija yra pagrindas, kuriuo mes ir tegalime remti karybos mokslą. Tik

\footnotetext{
${ }^{278}$ Ingaunis, [M]. Karo mokslo darbo technika. Mūsų žinynas, 1938, t. XXXIV, Nr. 1 (154), p. 106-121.
} 
karo istorijoj tegalime surasti tuos kriterijus, kurie veda moksliškumo, sąmoningumo keliu ị dabartinio karo reformas ir kurie teigiamai padeda išaiškinti karo patyrimą. Savaime suprantama, kad bestudijuojančiam karybą nepakanka vien tik istorijos, bet reikia susipažinti ir suderinti arba pritaikinti tą istorinị patyrimą naujausiems karybos reikalavimams. Karo istorijos konkrečios praktinès išvados, receptyviniai [kaip veikti] nurodymai, tai sustingęs karybos šablonas, kurị reikia performuoti ir sumoderninti. Neperformuotas, bet aklai priimtas karybos šablonas gali nuvesti tik ị pralaimejjimą. Tik kritiškas istorinis pažinimas, sujungtas su dabarties reikalavimais, gali duoti teigiamų vaisių. Darydami išva das dabarčiai, turime remtis praeities ir dabarties patyrimu [išskirta tekste - V. J.]. Pagaliau karo istorija padeda suprasti karo dvasią tiems, kurie nèra kare dalyvavę, kurie tik rengiasi būti kariais. Šiais laikais ne tik kariuomenè, bet ir visa visuomenè turi būti kariškai pasirengusi ir tuo būdu ji turi šiek tiek susipažinti ir su karo istorija.

Jeigu jau visų karo dalykų pagrindu yra karo istorija, tai ypač savoji karo istorija, savas kelias, nors ir su klaidomis, visada bus geresnis už kiekvieną svetimą. Patyrę ant savo kailio bent kokias klaidas ir jas pažinę, mes turime pasistengti ateityje jų nebekartoti. Pagaliau savoji karo istorija turi būti gyvu paminklu būsimoms kartoms, kad jos nepamirštuc, kokia kaina yra igyta tautos laisvé ir Nepriklausomybé, kad atlikti žygiai būtų kelrodžiai nugalèti visus būsimus mūsų tautos ir valstybès sunkumus [išskirta tekste - V. J.]. ${ }^{{ }^{2} 79}$

Remiantis tarpukariu Lietuvos kariuomenès leidiniuose skelbtomis publikacijomis galima apibendrinti, kokios metodologinès nuostatos buvo aktualios kariuomenès istoriją tyrusiems istorikams. Ar jų laikytasi, galima būtų nustatyti tik atlikus išsamų tarpukariu atliktų karo istorijos tyrimų turinio ir tyrèjų mokslinès veiklos analizę, tačiau tai jau atskiro tyrimo problematika. Šiuo atveju galima apibendrinti, kaip siūlyta ir siekta dirbti.

Karo istorijos analizè išpopuliarèjo XIX a. Vokietijos kariuomenès generaliniame štabe. Šị metodą ypač dažnai taikè Napoleonas ir C. von Clausewitzas. Karo istorija yra viena iš pamatinių karo mokslo šakų - tai „visų

\footnotetext{
${ }^{279}$ Mūsų karo istorijos reikalu. Mūsų žinynas, 1938, t. XXXV, Nr. 11-12 (165-166), p. $853-855$.
} 
karo dalykų pagrindas“ ir štabų karininkų atspirties taškas planuojant karines operacijas. Karo istoriją analizavo dauguma karybos teoretikų, bet ne dèl ịdomumo, o siekdami nustatyti „dabarties“ ir ateities uždavinių analogijas ir taip rasti jų sprendimus. Karo istoriko uždavinys - „priversti praeitị atsakinèti dabarčiai“, nes jis negali tik gilintis ị praeitị ir dèl to virsti visuomenei neịdomiu „muziejaus veikèju“, todèl būtina eiti ị visuomenę ir tapti „kartos vadu“. Kitų šalių karo mokyklų adeptai - tai grèsmè taikos metu rengiantis karui, o karo metu - veikiant, nes jie tinkamai neivertina vietos sąlygų. Todèl pavojinga atsisakyti savo karo istorijos tyrimų ir kliautis tik kitur atliktomis analizemis, nes savarankiškas kelias, kad ir klaidingas, mažiau grèsmingas nei kopijavimas. Dèl karo istorijos tyrimų trūkumų ir privalumų būta nuomonès, kad būtent tai neduoda karo minčiai sustingti. Tekstuose išryškejja dvi skirtingos tyrimų strategijos - remiantis viena, karo istorijos tyrimai negalimi tol, kol nuodugniai deskriptyviai ištiriama kariuomenès ir karų istorija, t. y. pasisakoma už atskirus karo istorijos šakų tyrimus; kita strategija - tyrinèti kompleksiškai, ką ypač Didysis karas atskleidè, kad, tarkim, atskiri karo istorijos ir karybos tyrimai negalimi, nes procesai pasidarè labai sudètingi ir susipynę.

Pradedant mokslinị darbą sudaromas preliminarus planas (turinys), nes darbo metu jis kinta (visi atvejai skirtingi, todèl neįmanoma pritaikyti šablonų) ir galutinis bus tik ji baigus. Atliekant tyrimus pirmiausia svarbu kelti probleminius klausimus, o ieškant i juos atsakymų: 1) susipažinti su esamais tyrimai, kad nebūtų imamasi tirti jau ištirtų reiškinių ar procesų; 2) surinkti kuo daugiau medžiagos tiriamu klausimu; 3) surinktą medžiagą susisteminti laikantis ne chronologinès, bet probleminès prieigos; 4) kritiškai ịvertinti atskirus faktus ir jų visumą, siekiant nustatyti ir užpildyti tyrimo spragas; 5) darbo - sintezès rašymas, kurioje turi būti faktografinè dėstomoji dalis, faktų analizè ir išvados. Pateiktų išvadụ praktinis taikymas yra ne istorikų, o karių kompetencija. Tiriamoji veikla turi būti planinga ir nuosekli - etapų vietomis sukeisti nedera. Skirtinga metodologiné prieiga yra tai, kaip „iš įvairių sekimo punktų mes matome ịvairias panoramas“, žvelgdami ị tą patị objektą. Sprendžiamos problemos pobūdis ir metodologinè prieiga - tyrimo metodų pasirinkimą lemiantys veiksniai, kuriuos tinkamai taikyti išmokstama tik praktiškai atliekant tyrimus. Tai - savotiškas meistriškumas, igyjamas su laiku.

Literatūros ir šaltinių skaitymas turètų būti kryptingas, nes neįmano- 
ma perskaityti „visko“, o jo metu svarbu žymètis, daryti išrašus, nes tai palengvins darbą vèliau. Šaltinių rinkimui - išskirtinis dèmesys ir kritinis jų vertinimas. Pirmiausia kaupiama vienalaikių šaltinių bazė, nes kuo šaltinis vẻlesnis, palyginti su ịvykiu, tuo mažiau patikimas. Faktai verifikuojami, ieškoma skirtingų šaltinių duomenų koreliacijos, nes atliekant karo istorijos tyrimus itin dažnai susiduriama su klaidingų faktų net iš pirminių šaltinių srautu. Dirbant aprépiamos ịvairios šaltinių grupès: dokumentai (reliacijos, ịsakymai, dienynai), įvairūs egodokumentai (laiškai, dienoraščiai, atsiminimai). Jei yra galimybè, rekomenduojama taikyti interviu metodą - apklausti ịvykių dalyvius ir liudininkus. Atliekant tyrimus išskirtine bibliotekos svarba: karinè biblioteka turi tureti katalogą, nes tai - ne knygų sandèlis, o mokslinio darbo laboratorija.

Karo istorikai savo darbuose turètų apžvelgti politines, karines, ekonomines, socialines ir kultūrines aplinkybes, pažinti tiriamo objekto aplinką, kontekstą. Be to, būtina apsibrèžti mokslinio tyrimo ribas, taikyti lyginamuosius parametrus, darbą pateikti recenzentams ịvertinti, rankrašti duoti susipažinti kuo daugiau tyrimo problemas išmanančių asmenų, viešai pristatyti tyrimų medžiagą prieš skelbiant, ją nuodugniai aptarti. Tirti būtina visą karo istoriją nuo seniausių laikų, nes be to neimanoma suprasti vèlesnių procesų, dèsningumų ir jų priežastingumo.

Pirmenybè teikiama karo istorikams karininkams, turintiems veiklos kariuomeneje praktinès patirties, nes apskritai istorikai (galintys parašyti puikų pasakojimą) nagrinejja procesus, neteikdami praktinių išvadų (strategijos, operacijų, taktikos ir karo organizavimo srityse) ir ateities rekomendacijų, nesirūpina, kaip su savo tyrimų rezultatais supažindinti karius, kuriems pirmiausia ịdomu, kaip jie gali būti pritaikomi. Pabrèžiant teorinių karo istorijos veikalų reikšmę ir jų ịtaką karo minties pokyčiams ir kartu pripažịstant, kad istorikas visada šališkas, būtina ịvertinti visus faktus, vengti ideologizavimo, išankstinès, šališkos nuomonės, nes tada galima susidaryti klaidingą vaizdą. Karo istorikai reikalingi, nes karo istorija svarbi karo mokslui, o tiriamoji veikla itin sudetinga, kai tyrimai atliekami dar gyviems jų dalyviams esant, kai sunku kritiškai vertinti visuomenès gerbiamų karo vadų veiklą, tačiau tai - karo istorikų pareiga, priešingu atveju tokie tyrimai neturi vertès. 


\section{IŠVADOS}

Karo istorija Lietuvos kariuomeneje tarpukariu laikyta pagrindine karo mokslų dalimi. Ji buvo svarbus karininkų rengimo ir kvalifikacijos kèlimo elementas, todèl dèstyta karo mokyklose ir kursuose, analizuota savarankiškai ir kolektyviai daliniuose, laikyti Lietuvos ir visuotinès karo istorijos egzaminai, pretenduojant $\mathfrak{i}$ aukštesnes pareigas arba vykti studijuoti ị užsienio karo akademijas. Tvirtinta, kad tik žinios apie vykusius karus ir jų analizè, t. y. karo istorija, gali padèti perprasti visus karo elementus, planuoti ateities karines operacijas, kurti naujas karybos koncepcijas.

Pabrèžtas būtinumas diferencijuoti karo istorijos tyrimus - kad taktikos, operacijų ir strategijos lygio tyrimai būtų orientuoti ị šių duomenų vartotoją. Taktikos, dažnai aprašomojo pobūdžio, istorijos tyrimai aktualūs jaunesniesiems karininkams, vadovaujantiems būriui ar kuopai, nes pabrěžta, kad karo istorija turi ne abstrakčias žinias jiems teikti, o padèti spręsti aktualias problemas esamuoju laiku, ypač karo veiksmų metu. Kareivių auklejjimo procese karo istorijai skirtas patriotinio, bendrumo jausmo, karinès tapatybès (ypač priklausymo konkrečiam daliniui, jo istorijos, šlovingos kovinès praeities pažinimo, suprantant tai kaip „mes, mūsų“) ugdymo, motyvacijos ir kovos dvasios kèlimo funkcija. Kadangi karininkai, ypač jaunesnieji, yra tiesioginiai kareivių ugdytojai, buvo svarbu, kad jie patys puikiai išmanytų karo istoriją, ją kareiviams dėstytų metodiškai ir net tam tikra prasme standartizuotai.

Karo istorijos svarba buvo pabrèžiama jau pirmaisiais nepriklausomybès metais. Ir tai buvo daroma grynai praktiniais sumetimais, o ne tik dèl abstraktaus pažinimo siekio. Remiantis karo istorija tikètasi išugdyti nacionalinị požiūrị i karybą, nes dèl savitų Lietuvos sąlygų remtis kitų, ypač didžiųjų valstybių, karybos rekomendacijomis buvo netikslinga ir net rizikinga. Doméjimasis apskritai istorija ir konkrečiai karo istorija buvo suvokiama kaip nuolatinè karininkijos, tiek aktyviosios tarnybos, tiek rezervo karininkų, veikla. Kariniuose leidiniuose plačiai rašyta įvairiais karo istorijos klausimais, o publikacijoms šia tema skelbti buvo įsteigtas atskiras leidinys - Karo archyvas.

Karinèje spaudoje tarpukariu permanentiškai teiktos ịvairaus pobū- 
džio metodinès rekomendacijos, parengtos Lietuvos autorių, arba užsienio autorių verstiniai tekstai. Taip siekta supažindinti su karo istorijos tyrimų organizavimu, vykdymu, mokslinių metodų taikymo ypatumais. Buvo atkreiptas demesys $\mathfrak{i}$ bendro istorinio konteksto ir lyginamosios prieigos svarbą atliekant karo istorijos tyrimus. Akcentuotas būtinumas prieš pradedant tyrimą susipažinti su darbais, surinkti ir kritiškai ịvertinti medžiagą ir tik tada imtis rašyti tekstą, kuris turejo būti recenzuojamas kitų asmenų, paliekant galimybę verifikuoti visus darbe pateiktus faktus. Taip siekta užtikrinti karo istorijos tyrimų mokslinę kokybę. Taigi tarpukariu Lietuvos kariuomeneje karo istorijai buvo skirtos dvi esminès funkcijos: 1) padèti pagrịsti karybos teorijas; 2) ugdyti karių tapatybę, pilietiškai juos auklèti, stiprinti ir palaikyti jų motyvaciją. O karinių dalinių ir apskritai kariuomenès istorija ir tradicijos buvo viena iš antrosios čia ivardytos karo istorijos Lietuvos kariuomeneje funkcijos igyvendinimo priemonių.

\section{SANTRUMPOS}

JAV - Jungtinès Amerikos Valstijos

KAM - Krašto apsaugos ministerija

KMD - Karo mokslų draugija

LCVA - Lietuvos centrinis valstybès archyvas

LDK - Lietuvos Didžioji Kunigaikštystė

SSRS - Sovietų Socialistinių Respublikų Sąjunga

VDU - Vytauto Didžiojo universitetas

Iteikta $2016 \mathrm{~m}$. rugsèjo $12 \mathrm{~d}$. 


\title{
L'HISTOIRE MILITAIRE ET SON IMPORTANCE DANS L'ARMÉE LITUANIENNE PENDANT L'ENTRE-DEUX-GUERRES
}

\author{
Dr. Vytautas JOKUBAUSKAS \\ Université de Klaipéda \\ Institut d'histoire et d'archéologie de la région baltique
}

Lécriture de textes sur l'histoire militaire et la science militaire a de profondes traditions, et les historiens des temps modernes ont une grande autoréflexion lorsqu'ils essaient de répondre à des questions telles que " qui sommes-nous », "qu'avons-nous accompli », " quel en est le bénéfice ", etc. La science moderne de l'histoire s'est développée en Lituanie pendant l'entre-deux-guerres et une certaine attention était aussi portée aux recherches sur l'histoire militaire. Le rapport de l'armée, un des éventuels " utilisateurs » des études sur l'histoire militaire, à l'histoire en général et l'histoire militaire en particulier est important dans ce contexte. Pendant l'entre-deux-guerres, l'histoire militaire est considérée dans l'armée lituanienne comme une partie essentielle des sciences militaires et c'était un élément important de la formation et du perfectionnement des officiers qui se manifestait par son enseignement dans les écoles et cours militaires, une analyse individuelle et collective dans les unités ainsi que le passage des examens en histoire militaire lituanienne et universelle pour ceux qui souhaitaient occuper de plus hautes fonctions ou partir étudier dans les académies militaires étrangères. Il a été affirmé que seule une connaissance et une analyse des guerres du passé, c'est-à-dire l'histoire militaire, peut dévoiler et permettre de comprendre tous les éléments de la guerre, planifier les futures opérations militaires ou créer de nouvelles conceptions en science militaire. Les généraux lituaniens Leonas Radus-Zenkavičius, Stasys Raštikis, Petras Kubiliūnas, Zenonas Gerulaitis et d'autres se sont résolument prononcés sur la nécessité pour les officiers d'étudier l'histoire militaire.

La nécessité de différentiation de l'histoire militaire a été soulignée pendant l'entre-deux-guerres : les études de l'histoire militaire au niveau 
de la tactique, des opérations et de la stratégie doivent être orientées sur des utilisateurs différents. Les études sur l'histoire militaire de la tactique, souvent de nature descriptive, sont d'actualité pour les officiers subalternes qui commandent un peloton ou une compagnie, car il était souligné que l'histoire militaire doit fournir aux officiers non pas des informations abstraites, mais les aider à résoudre les problèmes, notamment lors d'actions militaires, en temps réel. Dans l'éducation des soldats, on attribuait à l'histoire militaire la fonction d'éducation patriotique, du sentiment d'appartenance, de l'identité militaire (surtout au sens de l'appartenance à une unité concrète et de la connaissance du passé glorieux de cette unité, en comprenant cela comme "nous, notre ») et délévation de la motivation et de l'esprit de combat. Comme les officiers, en particulier les subalternes, étaient les instructeurs directs des soldats, il était important qu'ils connaissent eux-mêmes parfaitement l'histoire militaire et l'enseignent aux soldats avec méthode voire même, dans un sens, de manière standardisée.

L'importance de l'histoire militaire a été évidente dès les premières années de l'indépendance. Cela a été fait pour des raisons purement pratiques et pas uniquement pour la recherche d'une connaissance abstraite. En s'appuyant sur l'histoire militaire, on espérait former une approche nationale de la science militaire car, en raison du contexte unique de la Lituanie, s'appuyer sur les recommandations en science militaire des autres pays, et en particulier des grands, était inapproprié voire même risqué. S’intéresser à l'histoire en général et l'histoire militaire en particulier était perçu comme une activité permanente des officiers tant du service actif que de la réserve. Les revues militaires ont largement écrit sur les différentes questions de l'histoire militaire, une revue spécifique Karo archyvas (Archives militaires) a été créée pour publier les articles sur ce sujet. Des articles sur l'histoire militaire ont été aussi publiés par d'autres revues militaires: Karys (le Soldat), Kardas (Lépée), Mūsuz žinynas (Notre guide de référence), Trimitas (La trompette).

Il a été souligné que les armées des petits pays aussi doivent: 1) analyser la science militaire des éventuels ennemis pour identifier les faiblesses et trouver des solutions sur la façon de les exploiter pour organiser sa défense; 2) étudier la science militaire des alliés potentiels afin que, le cas 
échéant, une interaction soit possible ; 3 ) analyser sa propre expérience militaire pour évaluer quelles décisions stratégiques, opérationnelles et tactiques sont acceptables, peuvent être mises en œuvre par les forces militaires disponibles et donneront les résultats souhaités ; 4) collecter en général de la documentation et étudier la science militaire mondiale pour connaître le contexte de sa propre science militaire et de celle des ennemis et des alliés, comprendre l'évolution et les tendances des transformations. Des recommandations méthodologiques de différentes natures, préparées par des auteurs lituaniens, ou des textes traduits d'auteurs étrangers étaient régulièrement présentés dans la presse militaire pendant l'entre-deux-guerres, essayant ainsi de faire connaître l'organisation de la recherche en histoire militaire, sa réalisation et l'instrumentaire des méthodes scientifiques. On a souligné la nécessité avant de commencer une étude de prendre connaissance des travaux existants, puis de collecter et évaluer de façon critique la documentation, et seulement après commencer à écrire un texte qui devait être évalué par d’autres personnes, en laissant la possibilité de vérifier tous les faits présentés dans le travail et essayant ainsi de garantir la qualité scientifique des études en histoire militaire. L'Association des sciences de la guerre et la section Histoire de l'État-major de l'armée ont été actives dans les domaines de la promotion et la réalisation des études sur l'histoire militaire. 


\title{
MILITARY HISTORY AND ITS IMPORTANCE IN THE LITHUANIAN ARMY IN THE INTERWAR PERIOD
}

\author{
Dr. Vytautas JOKUBAUSKAS \\ Klaipéda University \\ Institute of Baltic Region History and Archaeology
}

Writing war history and military texts has a long tradition and present-day historians characterized by self-reflection are trying to answer such questions as 'who we are, 'what we have done', 'what are the benefits of this', etc. During the interwar period, when the modern science of history was developed in Lithuania, some attention was also devoted to the studies of military history. One of the eventual studies of military history is the ratio of the 'consumers' army with history in general and military history in particular is important in this context. During the interwar period, war history in the Lithuanian army was considered a key part of military science and was an important element in the preparation and training of military officers. It was taught in military schools and courses, and was analysed independently and collectively in the units. In order to be promoted or sent to study in foreign military academies, exams in Lithuanian and general military history had to be taken. It was argued that only a knowledge of past wars and analysis, namely military history, could reveal and help all the military elements to be understood, future military operations to be planned, or new concepts of warfare to be created. Lithuanian generals - Leonas Radus-Zenkavičius, Stasys Raštikis, Petras Kubiliūnas, Zenonas Gerulaitis and others strongly advocated the need for officers to study military history.

The need for differentiation of military history - the study of tactical, operational and strategic levels of war history which must be routed to different users - was highlighted in the interwar period. Studies of the history of military tactics, often descriptive, were relevant for junior officers, and officers who led a squadron or platoon, because military history would help to address problems, especially during current military 
actions, and not just provide abstract knowledge to officers. The function of patriotic education, sense of community, military identity (especially belonging to specific divisions and its history, and the knowledge of the past glory, of that sense of combat, understanding it as 'we, us'), and the motivation and raising of fighting spirit were dedicated to military history in the soldier's education. Since the officers, especially the younger soldiers, were direct educators, it was important that they had an excellent knowledge of military history, taught soldiers on a methodical and, to a certain extent, standardized basis.

The importance of military history was evident in the first years of independence. This was done only for practical reasons and not for an abstract desire for knowledge. Based on the history of the war, it was expected to formulate a national approach to warfare because of the unique conditions of Lithuania; to rely on the military recommendations of others, especially great states, was inappropriate and even risky. Interest in history in general and specifically in military history was perceived as a permanent activity by officers, both in active service and the reserve. Various issues on military history have been widely discussed in military publications, and a separate journal Military Archives was established to publish publications on this subject, other military journals also published articles on topics of military history, such as Karys, Kardas, Mūsu žinynas, Trimitas.

It was also emphasised that the armies of small states should 1) analyse the eventual enemy warfare in order to identify weaknesses and find solutions for how to organize the defence; 2 ) examine the potential warfare of allies with whom, if necessary, it would be possible to interact; 3) analyse their military experience to assess what strategic, operational and tactical solutions were acceptable and could be implemented by existing military forces and give the desired results; 4) collect the material and examine global warfare in order to know the context of warfare of their own, enemies and allies, and to understand the transformation process and trends. A wide range of methodological recommendations drawn up by Lithuanian authors or translated texts of foreign authors were regularly published in the military press in the interwar period with the aim of familiarizing them with the organization and execution of studies of 
military history, and instruments of scientific methods. The need before the start of the study for access to existing works, continuing to collect and critically evaluate the material and only then to write the text, which had to be reviewed by others with the possibility to verify all the facts of the work, was emphasized. This was to ensure the quality of the scientific study of military history. The Military Science Society and the historical section of the Army Staff were active in the promotion and enforcement of military history studies. 